\title{
Prioritizing Historical Archaeological Sites at Fort Leonard Wood, Pulaski County, Missouri
}

Carl G. Carlson-Drexler, Ellen R. Hartman,

April 2012

Carey L. Baxter, and Susan I. Enscore

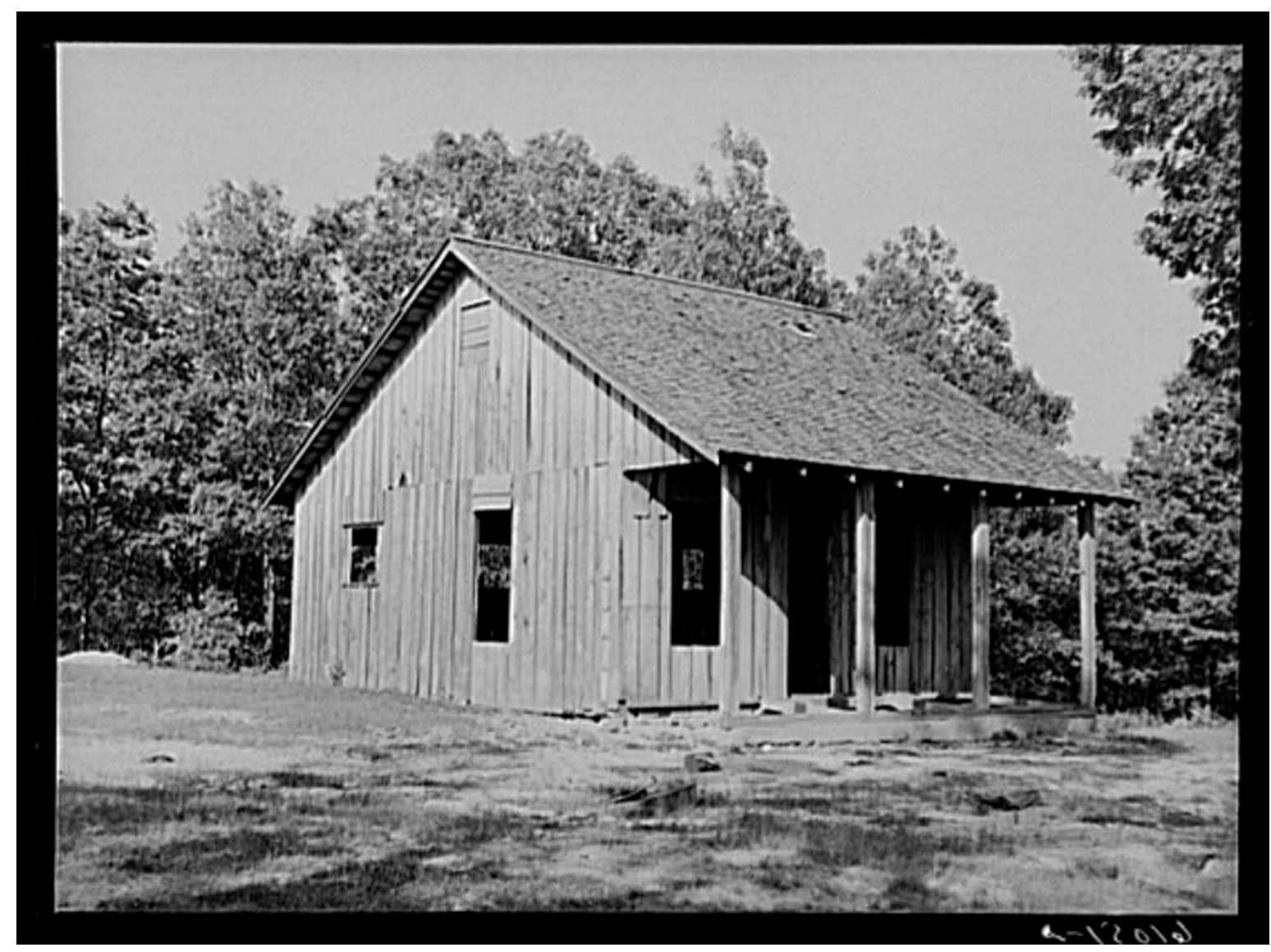





\title{
Prioritizing Historical Archaeological Sites at Fort Leonard Wood, Pulaski County, Missouri
}

\author{
Carl G. Carlson-Drexler, Ellen R. Hartman, Carey L. Baxter, and Susan I. Enscore \\ Construction Engineering Research Laboratory \\ U.S. Army Engineer Research and Development Center \\ 2902 Newmark Drive \\ PO Box 9005 \\ Champaign, IL 61826-9005
}

Final report

Approved for public release; distribution is unlimited.

\footnotetext{
Prepared for Fort Leonard Wood Directorate of Public Works Environmental Division

Fort Leonard Wood, Missouri 65473
} 


\section{Abstract}

The Army is tasked with managing the cultural resources on its lands. For installations such as Fort Leonard Wood that contain large numbers of historic farmsteads, meeting these requirements through traditional approaches entails large investments of time, personnel, and capital. Fort Leonard Wood and the Construction Engineering Research Laboratory have developed a model for efficiently identifying the best examples of historic sites, and also those sites that are least likely to be deemed eligible for listing on the National Register of Historic Places.

This report details the application of the data collection and analysis process developed by Enscore et al. (2005) to eight historic sites on Fort Leonard Wood Military Reservation. The results of the fieldwork show that this approach helps to quickly identify basic information about the site and provide a basis for identifying sites that have little potential for listing on the National Register. Recommendations also are offered concerning the development of the model and its application at other installations.

DISCLAIMER: The contents of this report are not to be used for advertising, publication, or promotional purposes. Citation of trade names does not constitute an official endorsement or approval of the use of such commercial products. All product names and trademarks cited are the property of their respective owners. The findings of this report are not to be construed as an official Department of the Army position unless so designated by other authorized documents. 


\section{Table of Contents}

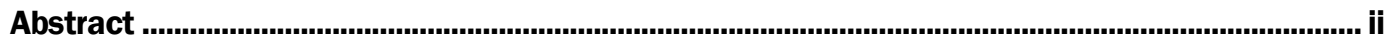

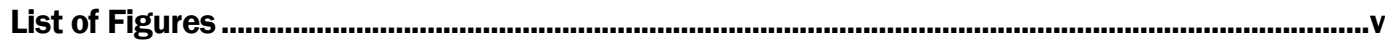

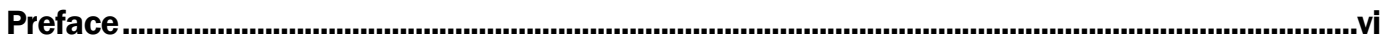

Unit Conversion Factors ..........................................................................................................vii

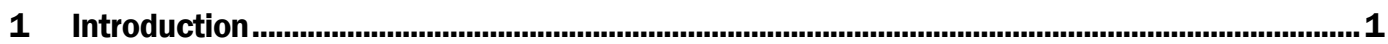

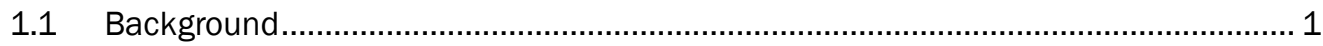

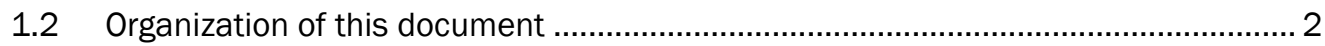

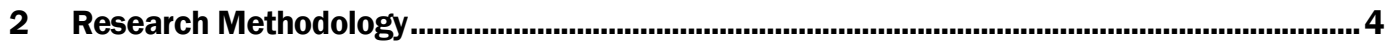

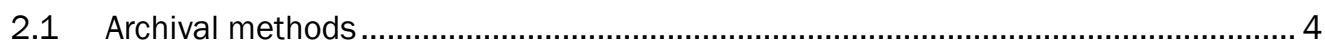

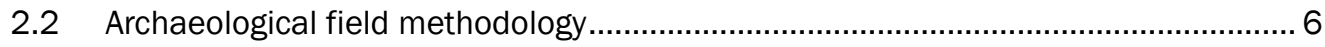

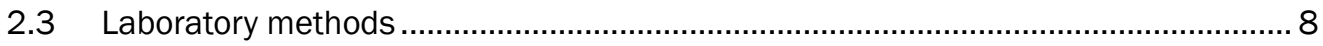

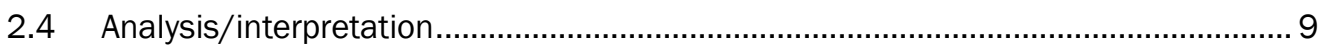

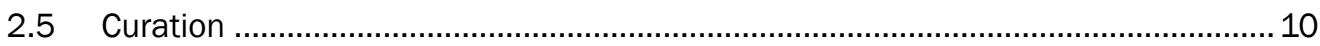

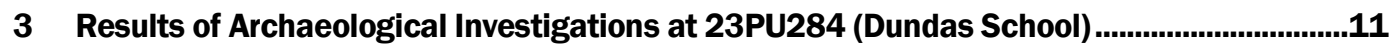

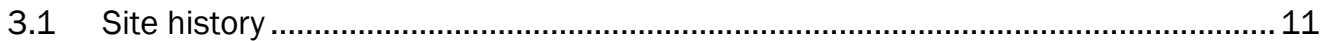

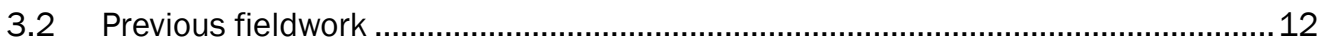

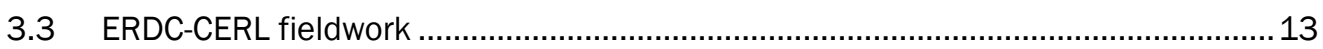

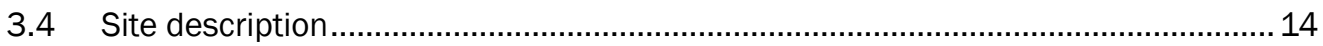

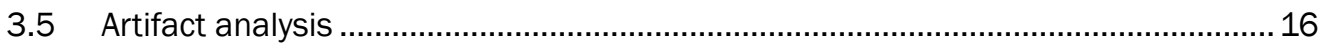

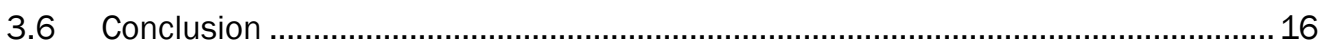

4 Results of Architectural Investigations of the Root Cellar at 23PU502 (Williams

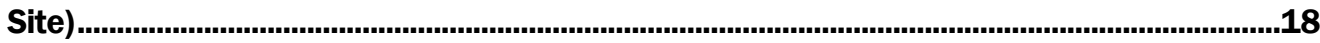

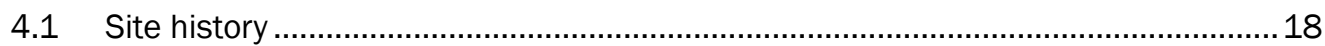

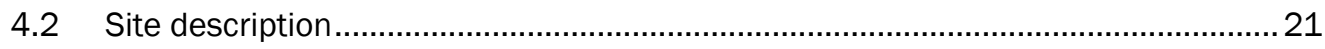

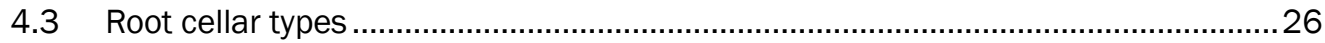

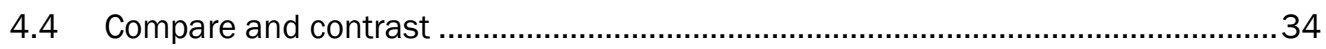

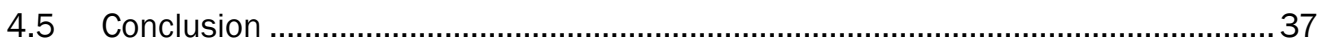

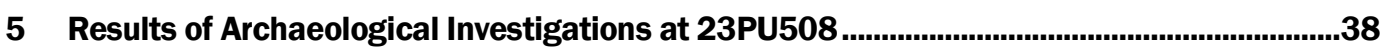

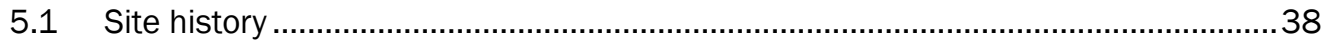

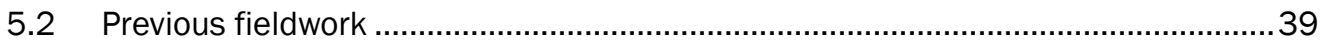

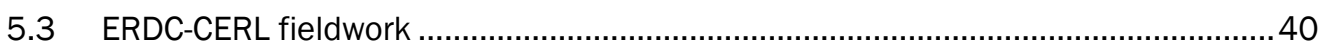

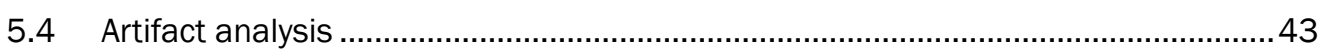

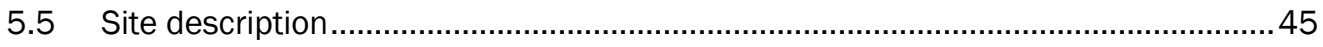

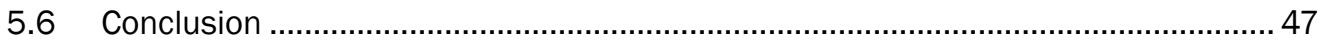

6 Results of Archaeological Investigations at 23PU509 (Bryun L. Christeson Site).................48 


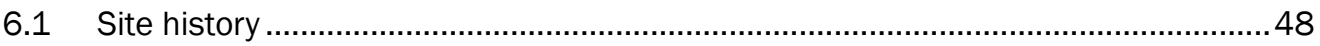

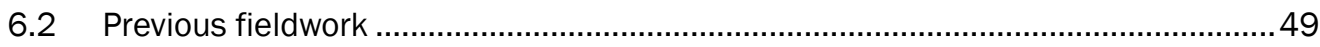

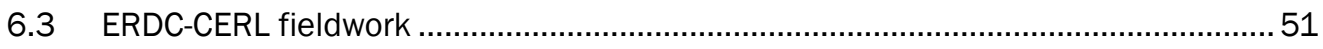

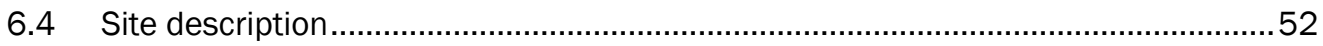

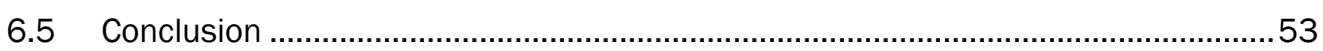

7 Results of Archaeological Investigations at 23PU510 (Dr. C. Mallette Site) ........................54

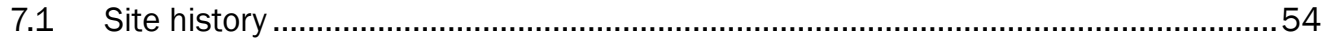

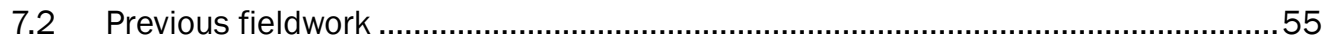

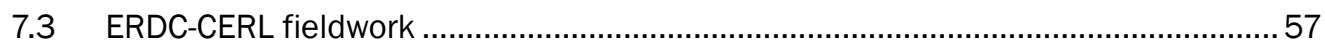

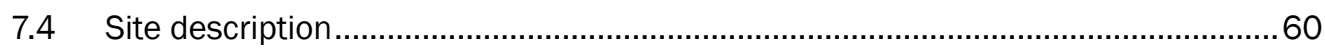

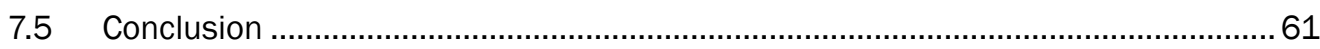

8 Results of Archaeological Investigations at 23PU511 (Zula Hicks Site)...........................63

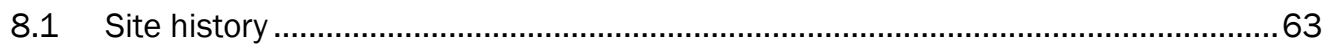

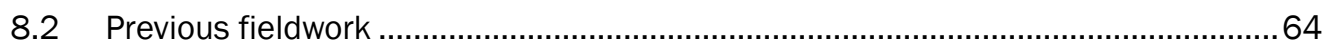

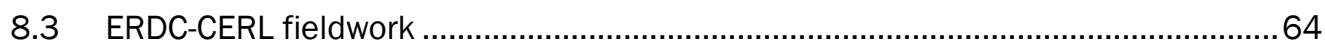

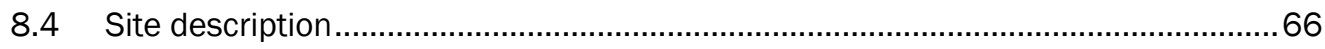

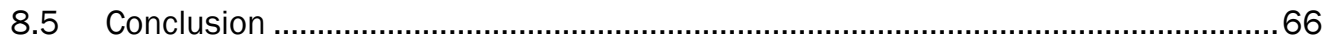

9 Results of Archaeological Investigations at 23PU512 (A.L. Hicks Site) .............................68

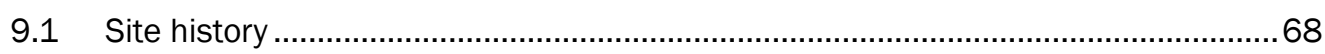

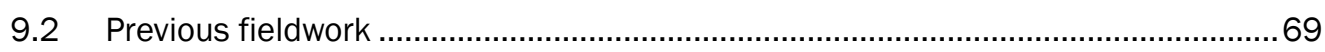

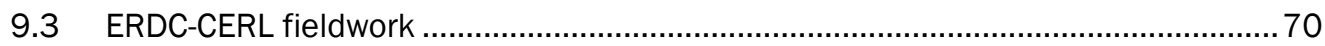

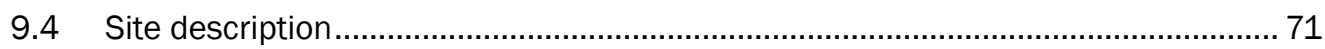

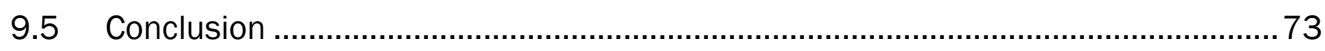

10 Results of Archaeological Investigations at 23PU548 (Lewis Lancaster Site) .................... 74

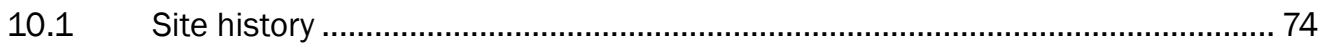

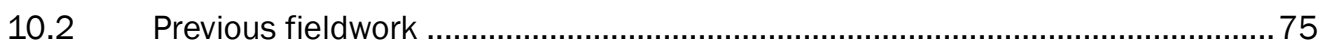

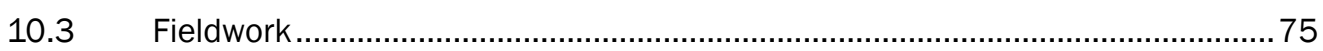

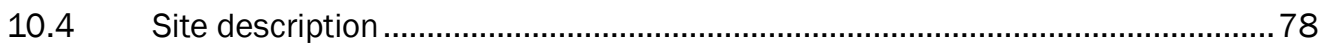

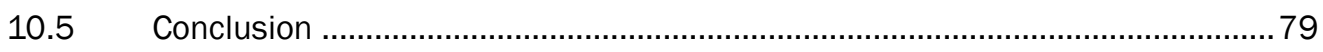

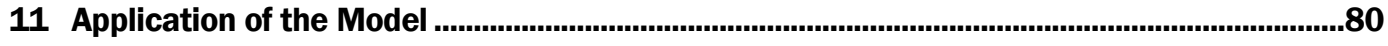

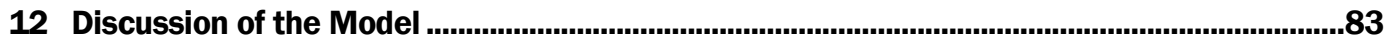

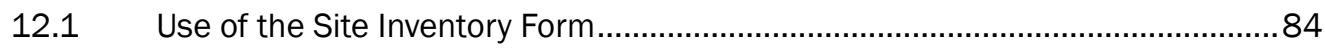

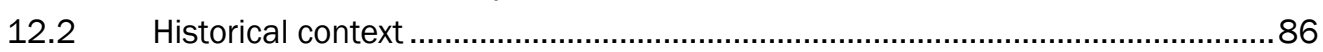

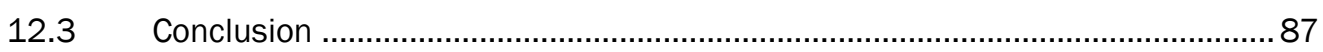

13 Conclusion ........................................................................................................................................8

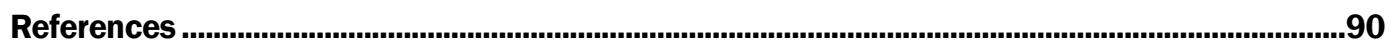

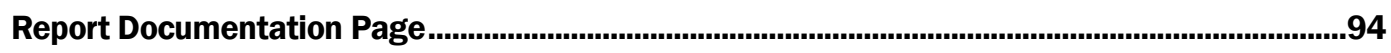




\section{List of Figures}

Figure 1. Dundas School in 1895 (left) and 1902 (right). (Images courtesy of the Pulaski

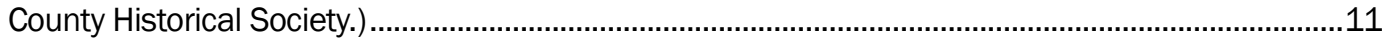

Figure 2. Map of 23PU284, Dundas School (PSAP). ...................................................................13

Figure 3. Broken pieces of concrete foundation, 23PU284, Fort Leonard Wood (picture taken in heavy rain, ERDC-CERL). ......................................................................................................15

Figure 4. Site map, 23PU284, Dundas School (ERDC-CERL)...........................................................17

Figure 5. Hand-drawn map of Williams farmstead by Patsey Williams Niebruegge, 2009. ..............20

Figure 6. Williams site farmstead remnants, based on archaeological investigation (Ahler

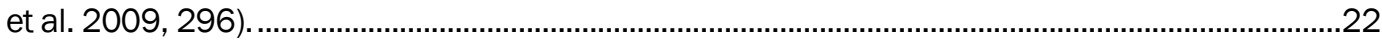

Figure 7. Stone buttressed walls of Williams root cellar, 2004 (ERDC-CERL).....................................25

Figure 8. Williams root cellar looking southwest (ERDC-CERL)......................................................2

Figure 9. Five basic types of root cellar construction (diagrams based on Gage 2009, 44). ...........27

Figure 10. Field or prairie root cellar, built entirely underground (Gage 2009, 89)..........................28

Figure 11. Example of an earthen-mounded cellar (Gage 2009)....................................................2

Figure 12. Example of an embankment cellar (Gage 2009)........................................................30

Figure 13. 1895 drawings for the "new plan for the construction of a storage cellar" (Alwood 1895).............................................................................................................................31

Figure 14. Williams site root cellar archeological investigation diagram, 2009 (ERDC-

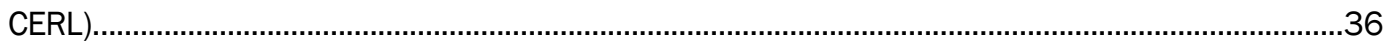

Figure 15. Buttressed stone walls of root cellar (23PU502), 2004 (ERDC-CERL)..............................37

Figure 16. Sketch map of 23PU508 (Adams 2003, 66)................................................................. 41

Figure 17. Artifacts from surface, 23PU508 (ERDC-CERL).............................................................42

Figure 18. Site map of 23PU508 (ERDC-CERL)..............................................................................46

Figure 19. PSAP map of fieldwork at 23PU509 (Kreisa et al. 1996). ...............................................50

Figure 20. Site map of 23PU509 (ERDC-CERL)............................................................................52

Figure 21. Sketch map of 23PU510 by Fort Leonard Wood archaeologists, 1994...........................56

Figure 22. PSAP map of 23PU510 (Kreisa and Adams 1999)........................................................57

Figure 23. Artifacts recovered from 23PU510 (ERDC-CERL). ..........................................................58

Figure 24. Site map of 23PU510 (ERDC-CERL).......................................................................59

Figure 25. Sketch map of 23PU511 (Adams 1997) . ....................................................................6

Figure 26. Site map of 23PU511 (ERDC-CERL).........................................................................67

Figure 27. PSAP map of 23PU512 (Adams 1997).....................................................................70

Figure 28. Site map of 23PU512 (ERDC-CERL) .......................................................................... 71

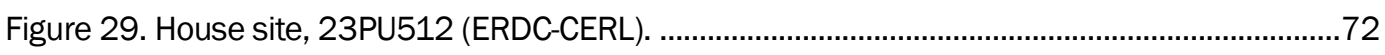

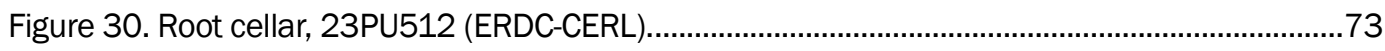

Figure 31: Site map of 23PU548 (ERDC-CERL)..........................................................................

Figure 32: Artifacts from 23PU548 (ERDC-CERL). ...................................................................... 


\section{Preface}

This study was conducted for Fort Leonard Wood under Military Interdepartmental Purchase Request (MIPR) 8MDATP3072. The technical monitor at Fort Leonard Wood was Ms. Stephanie Nutt, Cultural Resources Program Coordinator.

The work was performed by the Land and Heritage Conservation Branch $(\mathrm{CN}-\mathrm{C})$ of the Installations Division $(\mathrm{CN})$, Engineer Research and Development Center-Construction Engineering Research Laboratory (ERDC-CERL). The Project Manager was Michael L. Hargrave. At the time of publication, Dr. Christopher M. White was Chief, CEERD-CN-C, and Dr. J ohn Bandy was Chief, CEERD-CN. The associated technical director was Alan B. Anderson. The Deputy Director of ERDC-CERL was Dr. Kirankumar Topudurti, and the Director was Dr. Ilker Adiguzel.

ERDC-CERL is an element of the U.S. Army Corps of Engineers. The Commander and Executive Director of ERDC was COL Kevin J . Wilson, and the Director was Dr. J effrey P. Holland. 


\section{Unit Conversion Factors}

\begin{tabular}{|l|c|l|}
\hline Multiply & By & To Obtain \\
\hline acres & $4,046.873$ & square meters \\
\hline feet & 0.3048 & meters \\
\hline gallons (U.S. liquid) & $3.785412 \mathrm{E}-03$ & cubic meters \\
\hline hectares & $1.0 \mathrm{E}+04$ & square meters \\
\hline inches & 0.0254 & meters \\
\hline miles (U.S. statute) & $1,609.347$ & meters \\
\hline yards & 0.9144 & meters \\
\hline
\end{tabular}




\section{Introduction}

In August of 2009, Fort Leonard Wood requested the assistance of the U.S. Army Engineer Research and Development Center-Construction Engineering Research Laboratory (ERDC-CERL) in testing a methodology for evaluating historic period archaeological sites for National Register of Historic Places (NRHP) eligibility. Fort Leonard Wood currently manages 207 historic sites, many of which are farmsteads and isolated houses on its expansive training ranges. This report details the results of fieldwork focused on evaluating seven sites by ERDC-CERL archaeologists within the context of the model for evaluation developed be Enscore et al (2005).

\subsection{Background}

The National Historic Preservation Act of 1966 (NHPA), as amended, defines responsibilities Federal agencies have to historic properties under their oversight. Section 106 of the NHPA stipulates that federal agencies must take effects on historic properties into consideration when planning and completing undertakings which it regulates, funds, or which occur on its lands. It defines "historic properties" as those listed or considered eligible for listing on the National Register of Historic Places (NRHP). Additionally, Section 110 of the NHPA requires cultural resource managers to develop preservation programs to identify, evaluate, protect, and nominate historic properties to the NRHP.

There are Army-specific mandates regarding historic properties that supplement and support Section 106 and Section 110. Army Regulation (AR) 200-1 requires installations to develop integrated cultural resource management plans (ICRMPs), grounded in a landscape approach, to identify and manage historic properties on Army lands. Fort Leonard Wood's ICRMP does this (Edging et al. 2003).

As part of its ongoing program of regulatory compliance and cultural resources planning, Fort Leonard Wood has surveyed approximately $90 \%$ of its installation land looking for both prehistoric and historic archaeological sites. Prior to Army acquisition, the area's land uses consisted mainly of small farms and the rural communities that supported them. Purchase of the land for Fort Leonard Wood resulted in the loss of many Missouri communities including Bloodland, Palace, Evening Shade, 
Cookville, Moab, Tribune, Wharton, and Wildwood, along with hundreds of farmsteads and isolated houses. Previous archaeological surveys have found former towns, farmsteads, schools, churches, and other properties such as cemeteries. To date, 207 historic archaeological sites have been identified on Fort Leonard Wood lands. Located approximately 120 miles southwest of St. Louis, Missouri, and 85 miles northwest of Springfield, Missouri, the installation is adjacent to the Mark Twain National Forest. Occupying southern Pulaski County, and partially bounded by two waterways (Big Piney River and Roubidoux Creek), the area contains a variety of topographic features including water and floodplains, bluffs, rolling hills, and uplands.

One product of Fort Leonard Wood's cultural resources stewardship activities was Steven D. Smith's 1993 study Made in the Timber: A Historic Overview of the Fort Leonard Wood Region, 1800-1940, which provides a historic context for understanding and investigating the installation's historic archaeological sites. The Smith study employs a landscape approach in a chronological progression, providing information on the physical, commercial, and social development of the area before the creation of Fort Leonard Wood in 1940. Location-specific information and historic context, along with site integrity, are the basic prerequisites for evaluating the historic archaeological sites at Fort Leonard Wood for National Register eligibility. In order to complete the National Register evaluations systematically and efficiently, a means was needed to relate the historic context to the specific archaeological sites.

\subsection{Organization of this document}

Two distinct research approaches were applied to these sites. Seven sites were investigated archaeologically, while the eighth (specifically its root cellar) was studied as an example of the vernacular architecture of the Missouri Ozarks. Different approaches entailed different methods, and the divergences will be apparent in the organization of subsequent chapters.

This document reports investigations of the eight sites studied, presented in order of the site number assigned by the Archaeological Survey of Missouri (Chapters 3- 10). As mentioned above, one chapter (Chapter 4) gives the results of architectural investigations of the root cellar at 23PU502, the Wesley S. Williams site. Seven separate chapters detail the archaeological research on the other sites included in this study. The occupants of all these sites were once a community connected by kinship and social institu- 
tions, a community that was displaced by the founding of the fort at the start of World War II. Their homes remain clearly visible on the Fort Leonard Wood rangelands, although the occupants have moved on. Installation land managers must now determine how best to manage their former homesteads consistent with federal law. Key among these legal requirements is the evaluation of sites for eligibility to be listed on the National Register of Historic Places.

ERDC-CERL has worked with Fort Leonard Wood to develop a method for evaluating sites for eligibility more rapidly, a subject which is covered subsequent to the discussion of fieldwork in this report (Chapter 11). While an important step forward in the ability to speedily fulfill federal cultural resources mandates, there are some aspects of the model that bear revision. Suggestions for those revisions constitute the final chapter of this report (Chapter 12). 


\section{Research Methodology}

The research conducted by ERDC-CERL archaeologists on the sites at Fort Leonard Wood consisted of several elements, each of which recovered information that contributed to final estimates of the potential for each site to be considered eligible for listing on the National Register of Historic Places and aided in assessing the effectiveness of the significance model developed by Enscore et al. (2005).

Each of the sites involved in this review already had been researched at least minimally. This earlier research frequently meant little, however, beyond the level of documentation during archaeological surveys. Each chapter in this report includes a brief synopsis of previous work and eligibility assessments. These earlier findings informed, but did not constrain, the eligibility recommendations developed through this project.

ERDC-CERL research on these sites included archival, architectural, and archaeological field investigations (excavations and mapping), photographic documentation, artifact analysis, and the application of Enscore et al.'s model for eligibility recommendations. The sections of this chapter describe each of these steps in turn.

\subsection{Archival methods}

A few archival sources were consulted for primary documents relating to each site. This effort focused on identifying landowners and gathering a small amount of historical information that would help establish a rough chronology for each site. The archival sources also were useful to suggest possible dates for the initial and final habitation of the site as well as to identify significant changes in ownership or site function. This information was added to the Site Inventory Form for each archaeological site as the documents were reviewed.

Searches for documents pertinent to each site began with General Land Office patents, which record the identity of the first person to purchase the land. Missouri is one of the "general land" states, meaning its territory was initially considered property of the United States government, from which owners purchased their parcels. The General Land Office recorded those initials purchases, known as "patents" (Linklater 2002). These patents are 
available online in a searchable database provided by the Bureau of Land Management ${ }^{1}$.

Ownership and inhabitation did not necessarily occur at the same time, however. Immigrants to the Trans-Mississippi West frequently squatted on land long before they purchased it. This was particularly true for land of marginal agricultural value, which would not have been in high demand. Rocky Ozark land was frequently squatted for years prior to purchase (Bolton 1998; Rafferty 1980). The earliest documentation of ownership under United States law may postdate settlement by several years.

Historic maps constituted another source of pertinent information consulted in this project. Maps detailing Pulaski County and Fort Leonard Wood provided a trove of basic land ownership and land use information. The maps used in this project date to 1873, 1906, 1937, 1944, and 1948 and copies are on file in the Landscape Lab at ERDC-CERL. A plat book for Pulaski County dating to 1930 and available online from the University of Missouri archives, also proved useful (W.W. Hixson \& Co. 1930). Fort Leonard Wood also provided ERDC-CERL with a copy of the circa 1924 Pulaski County map (Higgins circa 1924), which shows land ownership.

Not all maps were of equal utility. For instance, the 1873 map of Pulaski County does not show structures or land ownership; therefore, it was of little use in this project. The 1930 plat book, the General Land Office patents, and the 1906, 1924, and 1948 maps of the region, which showed some of the kinds of information the other maps lacked, were more heavily relied on.

Wherever a name appeared associated with land pertaining to one of the archaeological sites in question, searches were made for more information regarding the individuals named and their families. The first resources consulted were the decennial census enumerated by the U.S. Bureau of the Census. These censuses identify, with very few exceptions, the people mentioned on the above-listed maps and patents, and occasionally offered genealogical data useful in understanding how the inhabitants of various sites were related.

1 http://www.glorecords.blm.gov/ 
In addition, the Secretary of State's office in Missouri makes available digital copies of death certificates for individuals who passed away within the state's borders between 1910 and 1959. Death certificates for several individuals associated with the sites studied during this project were identified. The death certificates provide some texture to the site interpretations by providing genealogical, biological, and historical data such as age, place of birth, parents' and spouse's names, occupations, and causes of death.

In rare occurrences, when official documentation could not be found, genealogical information made available in online resources were consulted and appear in a few places in chapters that follow. Where such sources are used (identified by the citation provided), conclusions should be understood to be tenable because the unverified nature of online genealogical information from nongovernment sites makes such sources inherently less reliable than official government documents.

\subsection{Archaeological field methodology}

The first part of the archaeological fieldwork phase involved locating the sites again, which was done with the aid of Mr. J oe Proffitt of Fort Leonard Wood's Department of Public Works (FLW/ DPW). Mr. Proffitt provided some site forms and drove ERDC-CERL archaeologists either to each site or to the vicinity of each site, which greatly aided completion of this task. For sites remote from the installation road, a Trimble GeoXH global positioning system (GPS) was used to guide the field crew to the site. Dense tree cover impeded the GPS' ability to determine its position, which made finding 23PU510 and 23PU512 a lengthy process. The spatial coordinates for the sites were gleaned from site forms provided by FLW/ DPW or obtained from the Archaeological Survey of Missouri's (ASM) "Archaeology Viewer."2

One other site, 23PU508, had to be surveyed apart from the others due to an inability to locate it during the first field phase in October 2009. Poor satellite availability coupled with confusion over the reference datum used for generating the site coordinates listed on the site form, prevented ERDC-CERL archaeologists from locating the site during their October field visit. During a subsequent trip in J anuary of 2010, Mr. Proffitt guided an ERDC-CERL archaeologist directly to the site, which he had flagged with tape between visits.

2 http://www.dnr.mo.gov/archviewer/ 
On-site methodology involved several different tasks. First, ERDC-CERL archaeologists performed a pedestrian survey of the entire site and the ground surrounding it for a space of 15-20 meters. This involved inspecting not only the obvious architectural features of the site, such as wells, stone-lined root cellars, and poured concrete foundations, but the ground outside the core of the site as well in hopes of identifying artifact scatters or other indications of activity in the area. In several cases, this survey identified additional features associated with the historic occupation of the site as well as its subsequent uses (e.g., locating foxholes related to military training exercises).

In some instances, site features noted in previous visits to the location were not locatable. For example, previous surveys of 23PU510 (the Dr. C. Mallette Site) identified silo footings and other outbuildings associated with what was once, in comparison to the other sites included in this project, a large agricultural site. Despite a thorough search extending well beyond previously-recorded site limits, the silo footings and one barn foundation were not located. This lack of finding was almost invariably the result of heavy ground cover, as undergrowth around many sites was very dense, even in October and J anuary when forest understory is usually relatively thin.

Second, two shovel tests were excavated at each site. These shovel tests were placed in areas judged by the archaeologists as most likely to yield useful information about the site, its stratigraphic context, and representative artifacts. The soil strata present were recorded by documenting texture and color (using the Munsell soil color system). All of these notations appear in the site descriptions that follow. Artifacts recovered from the shovel tests were bagged and brought back to ERDC-CERL for cleaning, analysis, and preparation for long-term curation.

Third, in several instances collections were made from sampling artifacts on the site's surface. This was done when temporally diagnostic artifacts, such as the medicine bottles at 23PU508, were seen on site. When surface collections were made, obviously recent material (plastic soda bottles, cigarette packages, etc.) from after the founding of Fort Leonard Wood were not collected.

Fourth, ERDC-CERL archaeologists used two techniques at each site to gather spatial data used in the creation of the maps presented in the fol- 
lowing chapters. Initially, sketch maps were made to capture subjective impressions of each site and its salient identifiable aspects. Next, a geospatially accurate map was made using the aforementioned Trimble GeoXH GPS, which was affixed to a Zephyr external antenna. This GPS/ antenna combination provides spatial precision to 30 centimeters. The site maps that appear in this document are composites of the sketch maps, GPS data, and maps of the sites made by previous archaeologists.

Finally, all sites were photographed using a Canon EOS Rebel digital SLR camera. Adverse field conditions, such as very thick forest understory and prodigious precipitation, made it difficult to capture large expanses of the sites in question with clarity. The photographs presented here document the state of the visible aspects of each site as effectively as was possible within the constraints of the climate.

The root cellar of 23PU502, a site previously investigated archaeologically, was subjected to a close analysis by a cultural geographer and two landscape architects from ERDC-CERL. These researchers documented the feature and produced a thorough analysis of the cellar itself, comparing it to other known examples of root cellars. (See Chapter 4 for a full description of the site.)

Archaeological fieldwork generated the information necessary to answer the questions posed in the Site Inventory Form, although excessively wet and rainy field conditions prevented recording the information in the field; thus, the inventory forms were completed based on fieldwork data once the archaeologists returned to ERDC-CERL.

\subsection{Laboratory methods}

The shovel testing of these sites yielded a small number of artifacts, primarily from the historic period. These and all field notes from the project are property of the federal government and, most directly, Fort Leonard Wood. The recovered artifacts and copies of all paperwork will be submitted to Fort Leonard Wood at the close of this project. Researchers interested in examining the artifacts recovered from this project should contact the Department of Public Works at Fort Leonard Wood to inquire about access.

In the field, all excavated artifacts were placed in paper bags marked with the installation name, date of excavation, site number, shovel test number, 
and the initial of the excavator or excavators. Artifact bags were kept in a centralized location while the crew was in the field. Upon return to ERDCCERL, all artifacts were removed from their bags, washed, allowed to air dry, and then placed in plastic bags marked with the same information as was written on the paper bags. The section of the paper field bag that bore the relevant contextual data was clipped from the bag and placed in the plastic bag along with the artifacts for the purposes of verifying its provenance.

\subsection{Analysis/interpretation}

Once cleaned and ready for bagging, each artifact was identified (where possible) and recorded in an artifact log for the site. Photographs were taken of some of the artifacts and appear in this report.

After all field and archival data were amassed, each site was analyzed for significance based on the Eligibility Prescreening Form and Site Inventory Form developed by Enscore et al. (Enscore, et al. 2005). The results of this process, along with some comments on the efficacy of the significance model, constitute the latter chapters of this report.

"Eligibility" in this case refers to whether or not the site should be considered sufficiently historically significant to be listed on the National Register of Historic Places (NRHP), a list maintained by the National Park Service of important historic properties around the United States. The National Historic Preservation Act (NHPA) of 1966, as amended, requires that sites that are considered eligible to be on the NRHP must be considered when federal entities, or non-federal entities that receive funding or oversight from the federal government, perform an undertaking.

The NHPA gives four criteria to be used in determining if a site may be eligible for listing. A site must have integrity and satisfy one of the criteria listed below (Neumann and Sanford 2001a).

- The site is associated with events that have made a significant contribution to the broad patterns of American history.

- The site is associated with the life of persons significant to American history. 
- The site embodies the distinctive characteristics of a type, period, or method of construction.

- The site has yielded or has the potential to yield information important to history or prehistory.

The last of these criteria is the one most frequently applied to archaeological sites, given the nature of archaeological inquiry. A site's "integrity," mentioned above, is a complex term linked to a site's condition. Neumann and Sanford (2001b) offer additional information on this term.

\subsection{Curation}

The artifacts for this project were initially curated at ERDC-CERL, locked either in an office or a secured storage room. Upon completion of this project, they will be transported for permanent storage to the American Archaeology Division, Museum Support Center of the Museum of Anthropology at the University of Missouri in Columbia, Missouri. 


\section{Results of Archaeological Investigations at 23PU284 (Dundas School)}

This chapter and the seven following it detail the results of archaeological and architectural investigations at each of the sites selected for analysis in this project. They contain a summary of known site history, previous fieldwork, and a description of fieldwork conducted by ERDC-CERL archaeologists. Each chapter closes with a synthesis and analysis of the site, based on the aggregation of various data sources pertaining to that site.

The first site so discussed is 23PU284, a poured concrete foundation for a building that once served as a school, worship center, and community gathering place for those in the area. It was known as the Dundas School.

\subsection{Site history}

The land where the Dundas School was built was patented in 1859 by Benjamin W. Ricketts (Bureau of Land Management 2010). Mr. Ricketts and his wife, Mary, maintained a large family of six children and one boarder in Roubidoux Township in 1870 (U.S. Bureau of the Census 1870). They do not appear in the 1880 census for the area.

The next documentation of the site's use comes from 1895, when photographs show the Dundas School had opened its doors to the area's students (Figure 1).
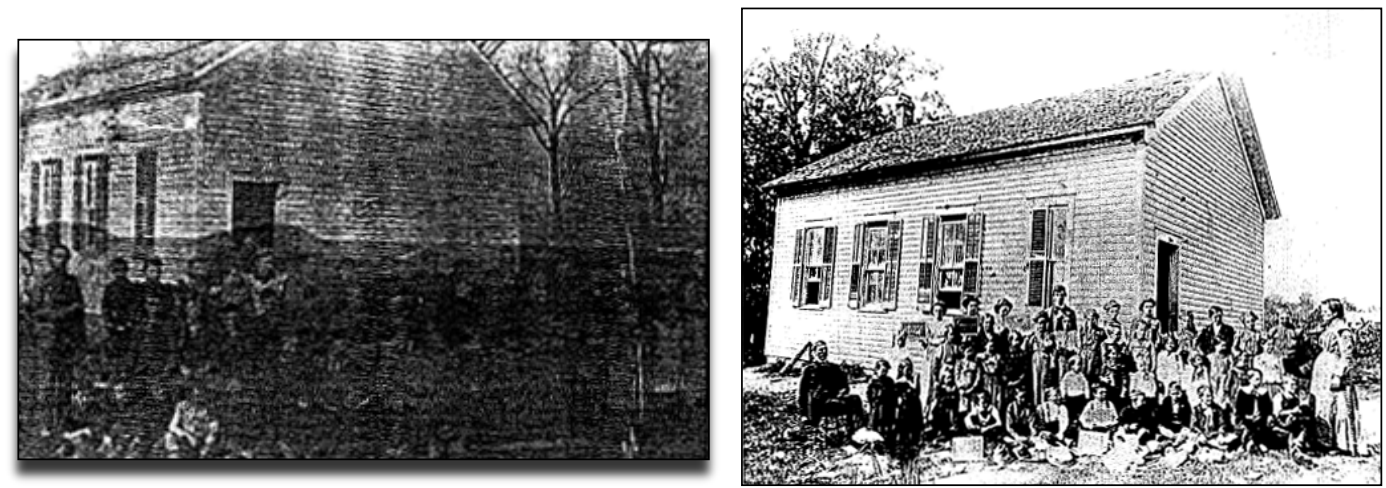

Figure 1. Dundas School in 1895 (left) and 1902 (right). (Images courtesy of the Pulaski County Historical Society.) 
The Dundas School served children from the local community, from the first through eighth grades. Nell York Miller, a former resident of the area, remembered the structure as being one room, furnished with a central wood-burning stove and a bookcase in the back. She also remembers there were six windows, three on each side, that allowed light in and a raised area at the front of the room. Some of these memories are corroborated by the photographs of the school, shown in Figure 1 (Kreisa, et al. 1996; Pulaski County Historical Society 2009).

In addition to serving as a school, the building operated as a community center and a Baptist church. Debates and tent revivals brought the community together at that spot on a regular basis to socialize and pray. These activities helped to bind members of the community together into a close social unit (Kreisa, et al. 1996; Pulaski County Historical Society 2009).

The schoolhouse was in place by 1895, when Figure 1 was taken. It appears on the 1906 map of Pulaski County, just north of a farmhouse. The school is still in place when the 1924 Pulaski County map was made. At that time, it was situated in the middle of a 38.5-acre tract owned by J.E. Christeson, who kept house on 160 acres located on the east side of the road running past the school house. The 1937 Pulaski County map, which shows churches and schools but not residences, shows the school. The 1944 map of Fort Leonard Wood shows the site, but refers to the facility as the "Dondas Church," instead of a school, 3 bespeaking the multiple functions the place performed as a community gathering place. The site finally appears as tract B253 on the 1948 Acquisition Map for Fort Leonard Wood, with the map showing a fee of $\$ 100$ paid to the Dundas School District.

\subsection{Previous fieldwork}

Site 23PU284 was first identified as an archaeological site and reported to the Archeological Survey of Missouri in 1982 by the private firm of Environmental Consultants, Inc. At the time, the site consisted of a cement foundation that was partially destroyed and two associated depressions, which were tentatively identified as a privy and a well. The site was determined to be 0.1 acres in size at the time (Kreisa et al. 1996).

The Public Service Archaeology Program (PSAP) from the Illinois State Museum shovel tested, mapped (Figure 2), and surface-surveyed the site

\footnotetext{
${ }^{3}$ Reference to the church uses the variation in spelling that is shown.
} 
in late 1995 or early 1996, during a Phase I survey of the McCann Cemetery Tract (Kreisa et al. 1996). The site was described much as it appeared in 1982, although dimensions of the foundation walls were provided (Section 3.4). A visual inspection of the surface at the site identified 25 fragments of brick, one piece of glass, and one piece of military metal hardware. Whether the glass was flat (window) or vessel glass is not noted, nor is a description of the "military metal hardware" given. No artifacts were encountered in the eight shovel tests dug at the site by PSAP (Kreisa, et al. 1996).

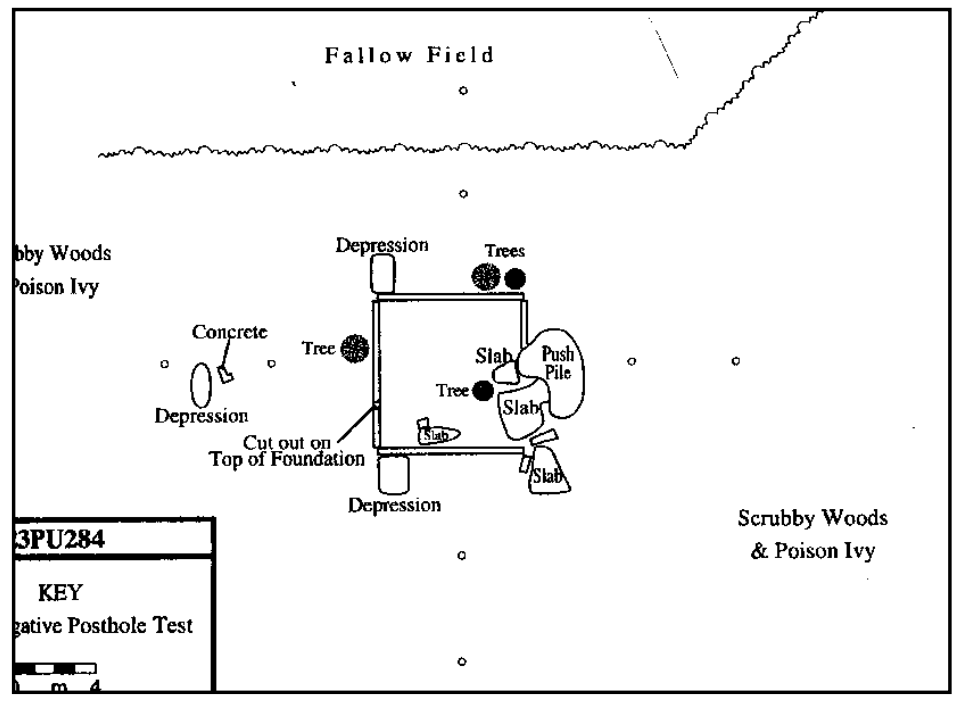

Figure 2. Map of 23PU284, Dundas School (PSAP).

Based on this fieldwork, Kreisa et al. (1996) suggested that the site was not eligible for listing on the National Register.

\subsection{ERDC-CERL fieldwork}

ERDC-CERL archaeologists performed a pedestrian survey of the site, dug one shovel test pit, and made a sketch map of the site. Fieldwork took place on 27 October 2009 under very rainy conditions.

The pedestrian survey started at the schoolhouse foundation and worked outward. To the west, the survey ceased at the parking area adjacent to the site. The extensive disturbance to the soil caused by the construction of the parking lot and the improvement of the adjacent road (which is contemporaneous with the site) negated any hope of identifying additional features associated with the schoolhouse. To the south, east, and north, the survey extended approximately 50 meters in each direction, in hopes of identify- 
ing more features than were previously documented. To the south, one depression, measuring $4 \times 1.5$ meters, stood adjacent to the road south of the site (Figure 4). This depression appears to be a foxhole or some similar feature associated with military training, given its dimensions and relationship to the road. It is not considered to be part of the site.

In 1996, Kreisa et al. found the only potential features, besides the school foundation, in the site to be three depressions, all in close proximity to the foundation, with nothing noted further afield. The ERDC-CERL surface survey of the area around the site supports this conclusion, since no other features besides the previously mentioned, probable foxhole were observed during fieldwork.

ERDC-CERL archaeologists excavated one shovel test pit at 23PU284, south of the schoolhouse foundation (see Figure 4). That test location was chosen based on the openness of the forest at that point. Also, it was felt that a shovel test pit inside the foundation, where it was once covered by a plank floor, would be less likely to yield artifacts than would one outside the schoolhouse, in the yard where photographs show people congregating and children playing.

The shovel test pit showed a regular progression of soil strata, though it was devoid of cultural material. A thin ( $0-5 \mathrm{~cm}$ below surface), black (10YR2/ 1) humic layer overlay a thicker stratum of silty clay (5- $25 \mathrm{~cm}$ below surface, 10YR3/2). Underneath these strata lay dark yellowish-brown clay subsoil (25- $42 \mathrm{~cm}$ below surface, 10YR4/4). Though both the subsoil and the overlying topsoil strata were silty clays, the subsoil had a noticeably lower level of silt content.

\subsection{Site description}

The site now sits immediately west of a parking lot near a storage facility at the entrance to Fort Leonard Wood's Range 14. It would appear this parking lot is a recent addition because it does not appear on the site map presented by Kreisa et al (1996), which marks the area as a "fallow field" (Figure 2). The area immediately surrounding the site is covered in undergrowth and small deciduous trees. During the fieldwork detailed above, the ground was completely covered by leaf litter, making surface inspection impossible. The site has been disturbed by some activity that resulted in the southern end of the building being pushed into the building interior 
(Figure 3). This disturbance took place prior to 1996, as Kreisa et al. documented it during their fieldwork.

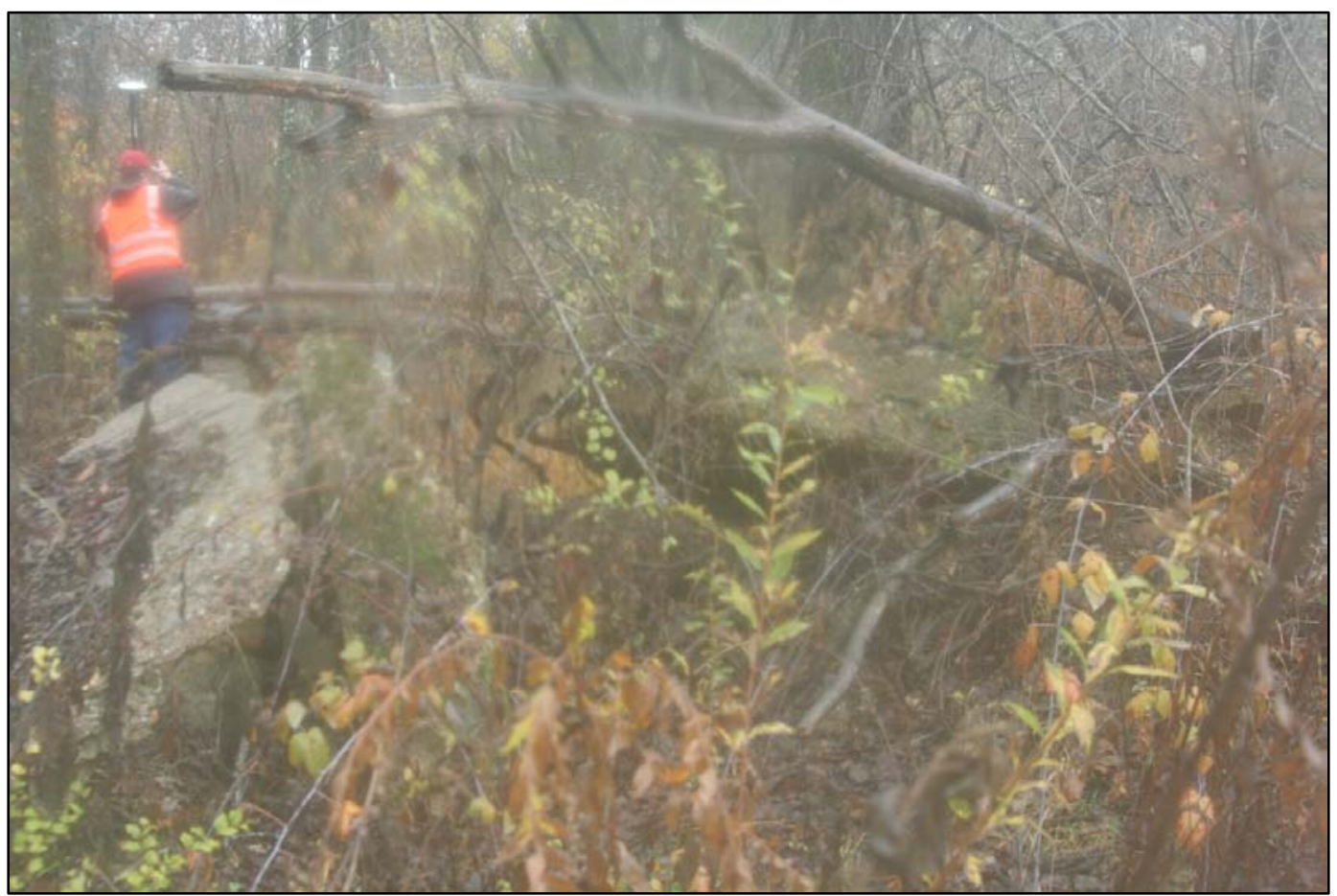

Figure 3. Broken pieces of concrete foundation, 23PU284, Fort Leonard Wood (picture taken in heavy rain, ERDC-CERL).

The building that once stood at 23PU284 was a small ( 6 x $6 \mathrm{~m}$ ), single pen building that served multiple functions. The presence of several small depressions in proximity to the foundation walls, initially identified in 1996 by PSAP, suggests the possibility of buried outbuildings being associated with the structure (Figure 4). From historical and archaeological research, we know that the building had a poured concrete foundation topped with a wooden superstructure that was covered with wooden clapboards. The south face had a door on its western side, and the west face had four windows with shutters. The roof was covered in wooden shingles. The chimney for the wood stove appears in the 1902 image of the school, exiting the roof at the north end of the building.

The site lies in the southeast quarter of the northwest quarter of Section 12, Township 34 North, Range 12 West. 


\subsection{Artifact analysis}

In all, five shovel test pits have been excavated at 23PU284, four by PSAP and one by ERDC-CERL. PSAP's shovel tests recovered 27 artifacts ( 25 brick, 1 glass, 1 metal), while the shovel test excavated by ERDC-CERL recovered no artifacts. Suffice it to say that this small assemblage adds little to our understanding of the site and its place within the historic landscape of Fort Leonard Wood.

This is not to say that the artifacts are completely bereft of value. PSAP's surface survey recovered 25 pieces of brick, which could indicate the presence of some additional feature or features. The images of the schoolhouse and existing remains of the site show significant use of concrete and wood as building materials, but the images do not give evidence of bricks being used in the schoolhouse.

The one fragment of glass found by PSAP could either be related to a vessel or window pane. Historic photos clearly show flat glass being used in sash windows in the building, while the use of the building as a school, church, or social hall would have presented many opportunities for vessel glass to be deposited on site. The piece of miscellaneous military hardware is likely more recent and related to military training activities in the area.

\subsection{Conclusion}

Previous archaeologists concluded that the Dundas School was not eligible for listing on the National Register of Historic Places. The intense disturbance to the site and its scanty artifact content were key points in arriving at such a conclusion. Additional fieldwork conducted as part of this project does little to offer a counterargument. Though unique in the small collection of sites considered as part of this project, the loss of the site's physical integrity and the limited archaeological information recovered to date suggest there is little to be learned by further research of this site. 

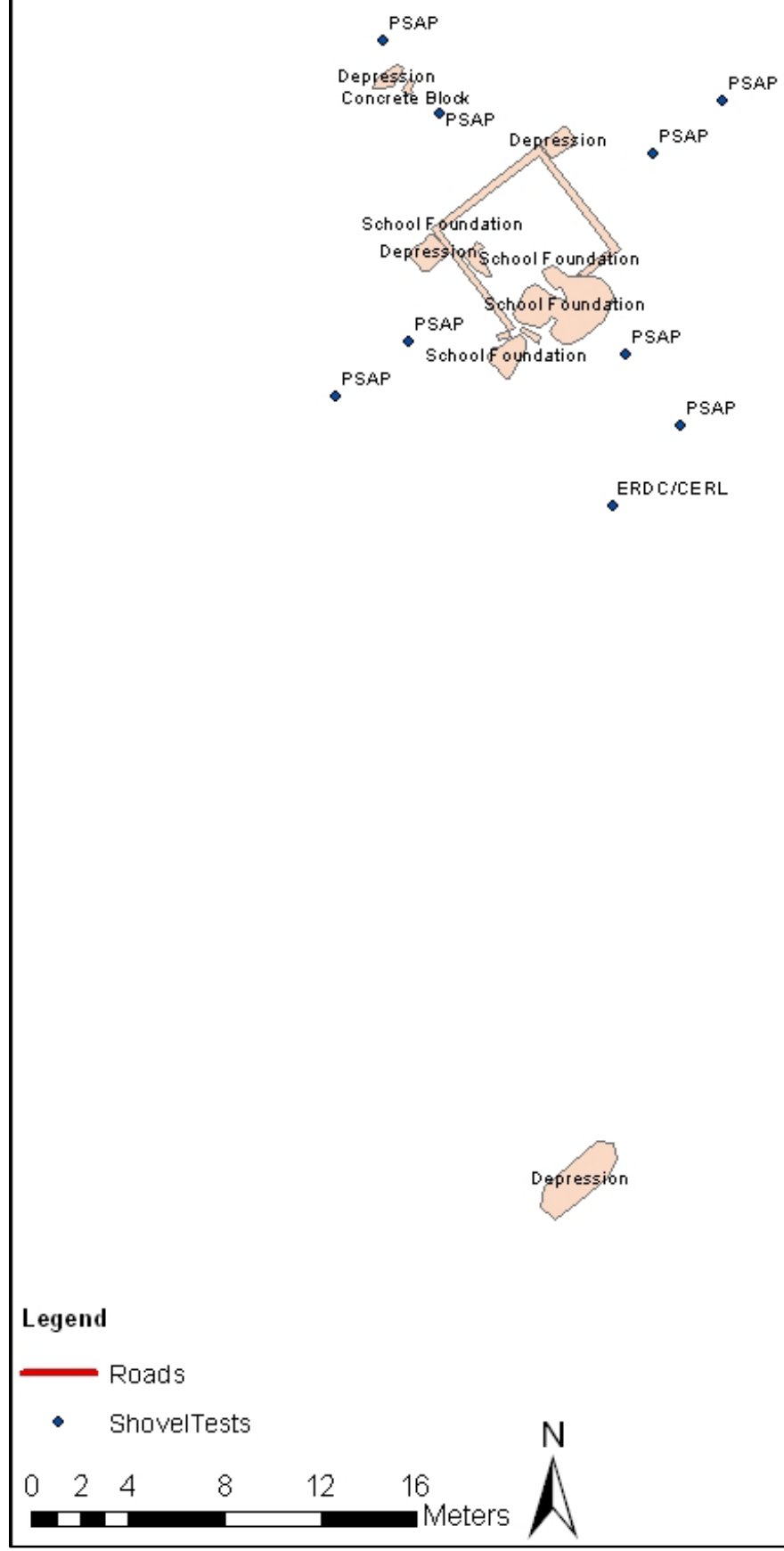

Depression

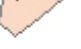

Figure 4. Site map, 23PU284, Dundas School (ERDC-CERL). 


\section{Results of Architectural Investigations of the Root Cellar at 23PU502 (Williams Site)}

Unlike the research at the other sites presented in this report, only one element of Site 23PU502 was analyzed during this project. This site includes a well-preserved root cellar, lined with local stone. ERDC-CERL geographers and architectural historians prepared the following summation of that research.

The site was heavily investigated archaeologically by Ahler et al. (2009), who argued that 23PU502 was eligible for listing on the National Register of Historic Places under Criterion D, scientific significance. They referenced the site's potential for contributing to "our growing understanding of the spatial organization of farmsteads; the integration of rural locations into national economic networks; the perception of economic, geographic, or cultural marginality of specific regions; and the origin and development of local vernacular architectural styles" (Ahler et al. 2009). ERDC-CERL's fieldwork at the site was not meant to re-evaluate Ahler et al.'s work. Rather, this research complements the archaeological fieldwork by studying the root cellar at the site from the standpoint of architectural history.

\subsection{Site history}

The Williams family lived in the homestead now known as the Williams Site (23PU502) from about 1881 until the U.S. Army bought the property in 1941. Wesley S. Williams and Malinda J ane Vaughan married in J une of 1881 and settled the site soon thereafter. Wesley Williams patented the land in 1895 (Bureau of Land Management 2010). The Williams household first appears in the U.S. census in 1900 (almost the entire 1890 Census was lost in a fire in 1922); the family consisted of the couple and their six children-Mattie, Luther Leonard, Isaac Lee, Hattie, Alonzo, and Thomas, ages one through 14 years. Wesley's occupation was recorded as a farm owner (U.S. Bureau of the Census 1900). A 1906 county atlas shows the W.S. Williams farmstead along the main road leading south from Bloodland, Missouri, to the county line. At the time, Williams owned over 160 acres of land, although in J uly of that year he released some acreage in the western portion of his farm for the new Waynesville-Houston Road right-of-way (Ahler et al. 2009). 
The 1910 U.S. census continues to record Wesley Williams as farm owner with his oldest sons living and working on the farm. A photograph from this time shows a framed farmhouse, one and a half stories tall, on a stone foundation. Two doors on the west side of the house open onto the front porch, which extended into a yard bordered with a picket fence. By 1924, the farm had grown to 200 acres.

In 1928 Malinda Williams, then age 62, suffered a stroke and died at the farmstead. Wesley continued living on the property, but his son Luther Leonard assumed farm operations. Wesley, along with Luther Leonard Williams, his wife Mary Etta Lancaster Williams, and their two sons were recorded at the farm on the 1930 U.S. census. The sons, Grover and Chester, were ages two and four. A daughter of Luther Leonard and Mary Etta, Patsey Williams was born in 1936. Both Patsey and Grover were interviewed for this project. Wesley retained ownership of the farm until his death in 1938, at which time Luther Leonard inherited the property.

Photographs and reminiscences from Grover Williams and Patsey Williams Niebruegge suggest the house was built in a typical nineteenthcentury Midwest and Southeast plan. The house was a vernacular halland-parlor, or double-pen construction, two rooms wide and one room deep with a half-story attic accommodating additional sleeping space. Originally the house had a kitchen ell centered on the east wall, but it was subsequently replaced by a new kitchen attached to the side of the house (Ahler et al. 2009). The kitchen ell extended from the south wall of the living room, with screened porches flanking it on the east and west sides. Locating the first kitchen ell on the back wall of the main house was standard practice for the period; however, the placement of the new kitchen ell on the side wall was unusual (Ahler et al. 2009). While uncommon, this location perhaps facilitated the continued use of the old kitchen as the new ell was constructed.

Patsy Williams Niebruegge drew a sketch map of the farmstead (Figure 5). Around the house was a fairly large yard with an abundance of flowers and catalpa and walnut trees. Looping past the west side of the house was the main road south from Bloodland. Immediately west of the road in a ravine was the springhouse. The springhouse had board walls with a stonework foundation serving as the catchment basin for the water. South of the house was the cellar. The cellar had stone walls and was built into the slope leading to an intermittent stream. The downslope walls were rein- 
forced with extensive stone buttresses. The cellar had space for potato bins and storage shelves for preserves and for corn, peas, and cherries canned by the gallon. "Above the cellar stood a wood-sided granary with an interior metal lining, a shed roof extended from its north wall providing a covered drive-through for farm wagons. Under the eave, tack and harnesses were hung from nails on the north exterior wall of the granary" (Ahler et al. 2009). Other outbuildings included a board-sided smokehouse north of the house and a well east of the house. A chicken coop, housing 12- 15 chickens and some guinea fowl, stood southeast of the main house. The outhouse was near the chicken coop. Uphill and east of both the outhouse and the chicken coop was a small barn, which served as a stable for horses. In addition to horses, the farm had goats and sheep in a fenced pasture across the drainage ditch west of the farmyard as well as pigs, cows, and "one old dog" (Ahler et al. 2009). South of the residence was a garden where the family grew vegetables, including beans, corn, parsnips, and sweet potatoes. The family also had a large orchard northeast of the farmstead with apple, peach, pear, and plum trees.

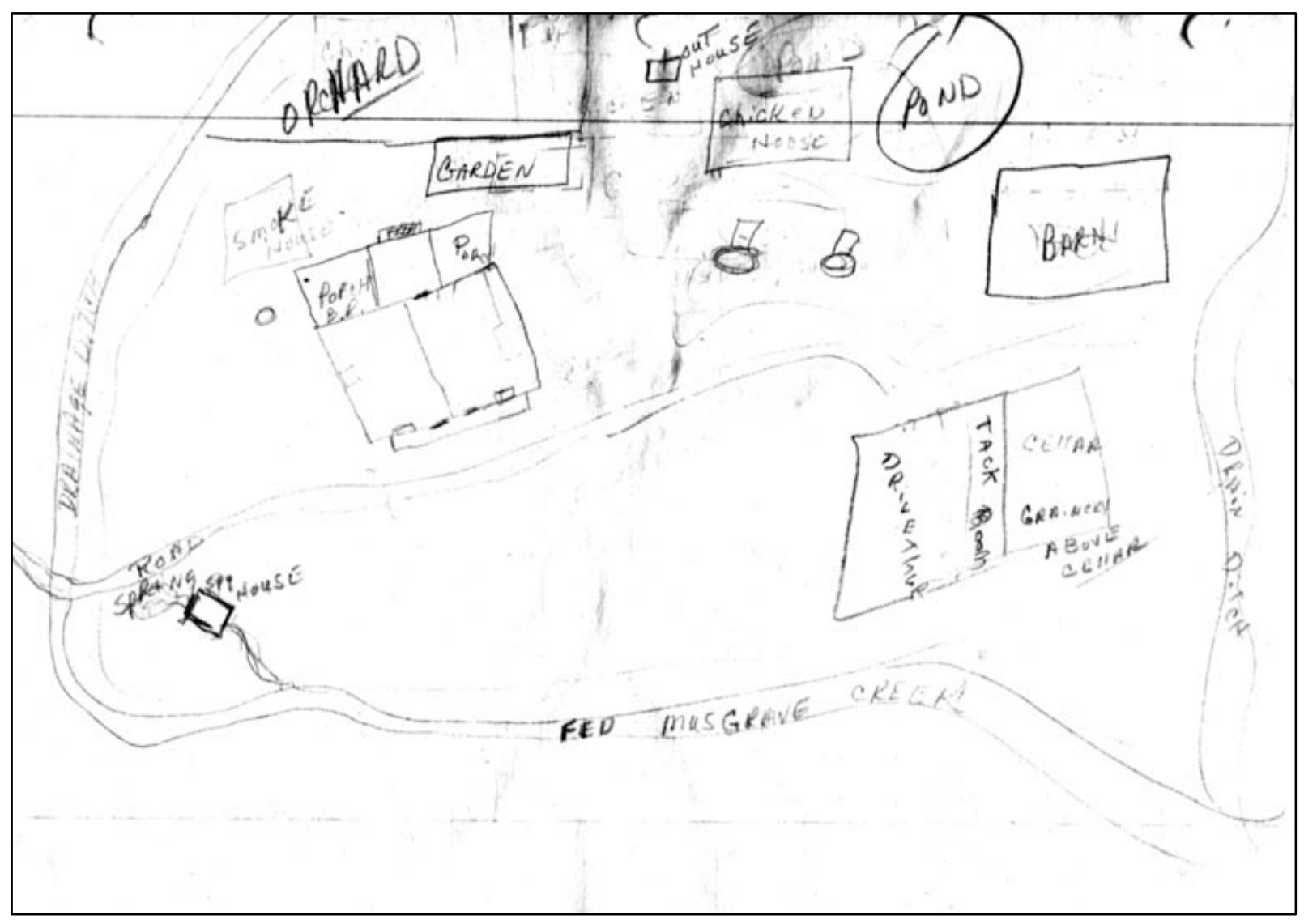

Figure 5. Hand-drawn map of Williams farmstead by Patsey Williams Niebruegge, 2009. 
The U.S. Army purchased Williams' property in 1941 (paying less than fair market value) and demolished the house. With uncertainty over where they were to go upon vacating the property, the displaced Williams family spent several years moving and living in temporary housing. Upon leaving their farmstead, they first moved into a goat shed owned by a man who operated the Palace store. After staying in the goat shed for a few weeks, the family moved to Old Evening Shade Church where they shared a house with another family. Later they moved in with one of their older sons, Chester Ray Williams, who owned a gas station and store at the junction of Highway AW and Missouri Route 17. After Chester Ray was killed in action on Okinawa while serving with the $382^{\text {nd }}$ Infantry, the Williams family moved to a farm near Roby, Missouri (13 miles south of Fort Leonard Wood), settling there in March 1946 (Ahler et al. 2009).

\subsection{Site description}

The Williams farmstead was located on a ridge slope adjacent to an intermittent tributary to the creek that runs down Musgrave Hollow. The farmstead can be reconstructed from archaeological investigations and oral histories. The site was a typical late nineteenth-century Missouri settler farmstead in its arrangement of spaces and outbuildings. Settler farmsteads were generally organized according to environmental conditions and the suitability of terrain, meaning that buildings were located according to purpose and frequency of use (Hervert and Allen 1980).

Accordingly, the Williams' farmstead employs the basic patterns of farmstead layout, but does depart from the norm in several ways. Similar farmsteads usually focused around the residence, with outbuildings circling it, but located away from the main house. The function of an outbuilding dictated its spatial relationship to the house. The smokehouse, springhouse, well, and storage cellar-all buildings storing goods needed on a daily basis and not a threat to health-clustered near the house. Conversely, the privy, chicken house, and barns, which were either less important to daily household activities or more of a health risk, were located farther away (Smith 2003).

As shown in Figure 6, the Williams homestead was unusual in that a public road runs along the top of a drainage ditch directly west of the house, between the storage cellar and the residence. Drainage also determined a building's placement, and the Williams site unusually located the privy and barn at a higher elevation then the house; although they likely drained 
away from the farmstead. These two departures aside, the house and outbuildings were located and organized in a manner fundamentally consistent with nineteenth-century settler farmsteads (Ahler et al. 2009).

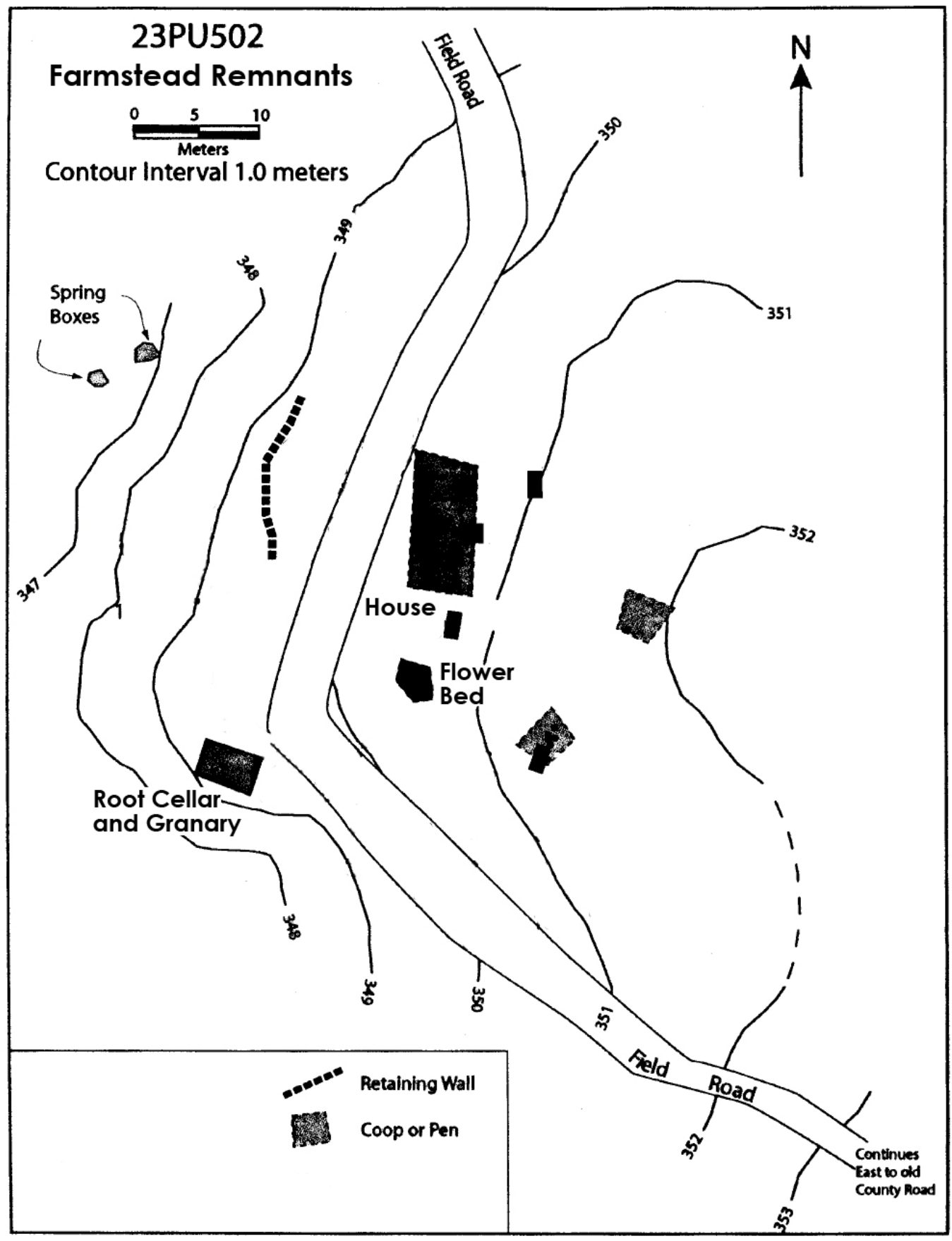

Figure 6. Williams site farmstead remnants, based on archaeological investigation (Ahler et al. 2009, 296). 
One of the more interesting structures on the Williams property was the combination of storage cellar and granary. This building was located southwest of the main residence and possibly dates to the early 1880s, when Wesley and Malinda Williams first moved to the property (Ahler et al. 2009). Though located near the house, a public road runs through the house yard, separating the cellar from the main house. Such an arrangement was unusual, but it may have been the optimal location for the cellar. Specifically, the cellar was built into the steep side slope of an intermittent drainage ditch. The walls on the downhill side were thickly buttressed with dry-laid stonework meeting the uphill slope flush with the ground surface. The buttressed walls extended out to support the floor of the granary. The stonework and hillside setting are similar to another root cellar (23PU398) at Fort Leonard Wood, indicating that the Williams cellar could represent a local building tradition of the late nineteenth century (Ahler et al. 2009). Such a construction method, which depends on the use of the local topography, makes the arrangement of buildings subject to the landscape of the site.

Not only is the Williams' storage cellar uniquely located in relation to the residence, it also is a rare example of the combination of two types of storage structures. The storage cellar on the Williams' property served as the foundation for their granary. While demolition conducted by the Army has severely disturbed the site, much of the storage cellar walls remain intact. The original appearance of the structure can be envisioned from the physical remains and oral descriptions by former residents of the site. The storage cellar employed typical construction techniques of buttressed, dry-laid stonework walls on the exterior with concrete and timber construction on the interior (Figure 7). According to Grover Williams, son of Luther Leonard Williams, the storage cellar contained wooden bins for vegetables and shelves on one side for canned goods. The potato boxes were to the right of the entrance, and the shelves were straight ahead. This allowed for standing room inside on the left, where everyone would gather during storms (Williams 2009). According to Patsey Williams Niebruegge, the storage cellar had a wooden door that opened out and was insulated with sawdust compacted between two planks (Niebrugge 2009). Usually cellars built into a slope used the surrounding earth for insulation (Figure 8). In this case, with the storage cellar serving as a foundation for the granary, the ceiling of the cellar would have been insulated in some way. Archaeological investigations found five large timber fragments situated in the cellar interior, perhaps remnants of floor joists for the overhead granary (Ahler et al. 
2009). It can be speculated that since the door used sawdust, the ceiling of the cellar might have used sawdust as a method for insulation.

The granary built over the cellar was frame construction with metal floors and walls measuring five or six feet high, and stood about eight feet tall overall. It had a gable roof with round pole rafters. Two of these supported a ten or twelve foot wide shed roof, the peak of which was oriented the same as the house. On the north side was a lean-to shed covering a doorway also on the north side. Stored under the covered space were harnesses and horse tack, and wagons could be moved into the space for shelter. The floor of the granary extended beyond the walls of the storage cellar and was supported by the stone buttressing of the cellar. The granary originally only stored wheat because corn was stored in the corn crib on the west side of the barn. Eventually though, the granary stored wheat and corn before they were taken to town for grinding. The wheat was traded at the mill for flour and the corn was ground in a one-cylinder "grounder" at the Palace store (Niebrugge 2009). The granary served a critical function on the Williams farmstead since the family only made two trips a year to town with wheat for grinding.

The combination of storage cellar and granary seems to be unique to the Williams' farmstead. Whether they lacked space for a separate granary or located the granary where it was convenient to build a cellar is not known. Both structures were constructed in a manner typical to the late nineteenth century and the area, yet there were variations in the combination that makes the combined structure fairly uncommon. 


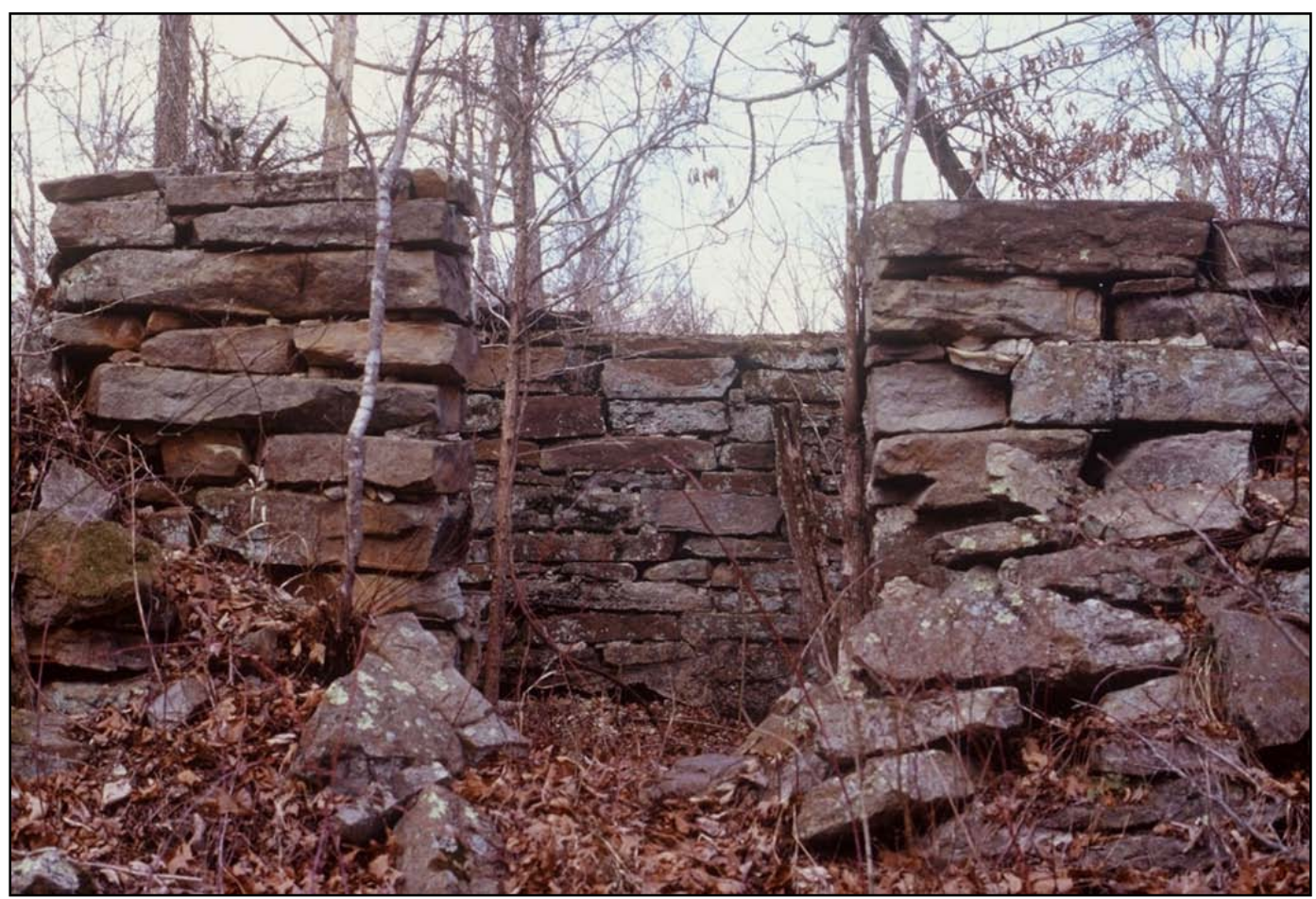

Figure 7. Stone buttressed walls of Williams root cellar, 2004 (ERDC-CERL).

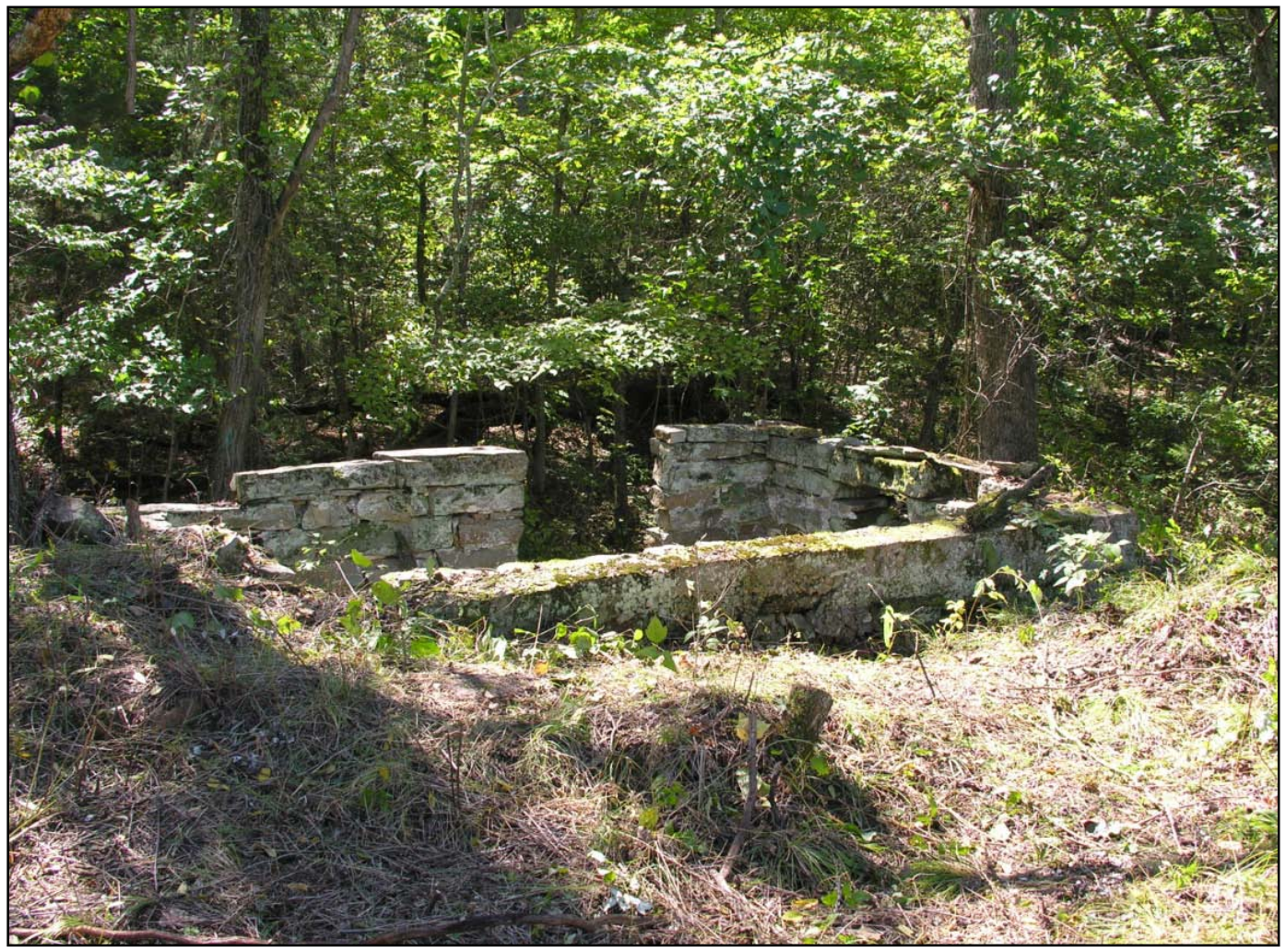

Figure 8. Williams root cellar looking southwest (ERDC-CERL). 


\subsection{Root cellar types}

The primary purpose of a storage or root cellar is food preservation. Most commonly known as root cellars, they provide long-term storage for root crops such as potatoes, carrots, parsnips, and turnips. Cellars also store cabbage, beets, onions, and apples as well as pickled and preserved foods throughout the winter and early spring. Cellars keep foods in a dry, consistently cool, and relatively humid environment. Cellar construction ranges from simple to complex, ranging from field and subfloor pits to semi-subterranean, freestanding structures. The origins of root cellars are traced to early American colonists adopting Native American storage structures and techniques (Gage 2009).

Below-ground storage pits were easy to build and were widespread, often being dug under the floorboards of colonists' houses. Less common in the eighteenth century were the more elaborate, freestanding structures and cellars constructed in farm outbuildings (Gage 2009). Recognizing the necessity of root cellars, the 1829 Encyclopedia Americana finds, "They [Americans] are rarely destitute of good cellars, which the nature of the climate renders almost indispensable" (Gage 2009). By the mid-1800s, freestanding or semi-subterranean cellars of stone construction became the prevalent form for root cellars. These were either dug below an entire structure, under a portion of a house, under a farm outbuilding, or were a freestanding structure. Freestanding cellars, as opposed to floor pits, accommodated more storage room and provided more control over the cellar environment.

Outbuilding cellars date from the eighteenth century, where cellars would be built under a farm outbuilding. On the Sodus, New York, farm of Dr. William Cook in the mid-1800s, the rutabaga cellar was under the tool house and workshop and was filled by "dumping the cart through a hole above, provided for the purpose" (Gage 2009). More commonly, the cellar was incorporated into barn construction, where food for the farm family could be stored along with winter feed for animals.

A rise in barn cellars for root crop storage correlates to the rise in commercial farming in the nineteenth century. The most economical strategy for incorporating a cellar into a barn was to construct an insulated room in the basement. This was typically done by ramming earth between wooden planks and insulating it with hay on the top and sides. Other building methods of barn cellars that were more expensive, and therefore less 
common, include extending the room out from the barn foundation into an embankment or into the earthen ramp leading to the first floor of the barn. These types utilized the insulating properties of the earth and offered more protection from freezing. A major problem of this type of cellar was the uninsulated ceiling. Protecting the crops from freezing could be accomplished with a thick layer of straw, but by the late 1800s farmers were experimenting with insulating the floor above. Strategies for this were insulating between floor joists, using a double floor system with air space, or having the inside walls and ceiling "sheeted and battened" (Gage 2009). Floors in these cellars are assumed to be dirt; however in 1872, a recommendation suggested floors should be paved and sealed with a water-lime mortar. As cellars became larger and held more produce, proper ventilation was needed. Incorporation of slatted wooden floors and storage bins increased air circulation around stored crops, while window and ceiling vents were designed to draw in clean air.

Freestanding cellars applied many of the building techniques and insulating strategies used in barn cellars; likewise, these structures had a variety of designs that were carefully thought out and constructed. Many improvements sought to reduce losses and extend the length of storage, use new building materials and techniques, and adapt the structures to new environments like the prairie. Despite the variety, five basic freestanding cellar types have been identified by J ames Gage in his book, Root Cellars in America. The five types are: above-ground, non-mounded cellar; the half cellar; below-ground cellar; the earthen mound, natural or man-made cellar; and the embankment or hillside cellar (Figure 9). Within these types, the construction materials and methods of the roof, walls, floor, entry, ventilation, and drainage vary greatly (Gage 2009).
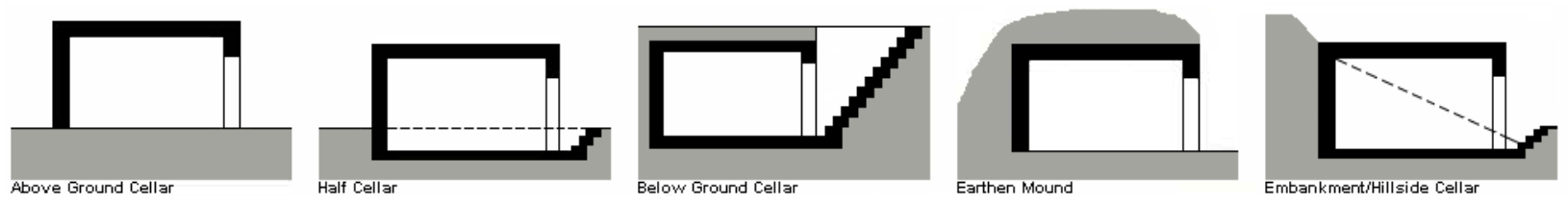

Figure 9. Five basic types of root cellar construction (diagrams based on Gage 2009, 44).

Above-ground and half cellars are characterized by having exposed walls. These cellars are usually found in temperate climates, where the possibility of freezing is minimal. The difference between the two is that the half cellar has a minimal portion of the structure built into the ground. Because the walls were exposed, both types used similar construction techniques to insulate the walls and roofs. Wall construction was either thick concrete or 
a double-wall system that allowed insulating material to be placed in the interior space. Brick and stone masonry walls needed to be thick, usually 18 to 24 inches, and concrete walls needed to be at least eight inches thick. Walls made from logs or wooden planks used a double wall system, which had an interior space that could be left as dead air space, or filled with earth, leaves, or straw for insulation (Gage 2009).

In harsher climates, like the flat Plains states, cellars were often built entirely below ground. Also known as field or prairie root cellars, this type of cellar is specifically designed for flat lands with no hills or embankments (Figure 10). Construction of these cellars was intensive. A trench was dug to at least six feet deep, the walls were lined with stone, brick, or wooden planks and poles supported a wood-plank gabled or flat roof. The roof was generally covered with earth and then a layer of sod. Access was through a hole in the roof or by a stairway entered through a bulkhead. The exposed entrance was insulated with straw. With entrance either through a hole in the roof or through a heavily insulated doorway, this type of cellar was cumbersome to access and was replaced by different types when the means became available (Gage 2009).

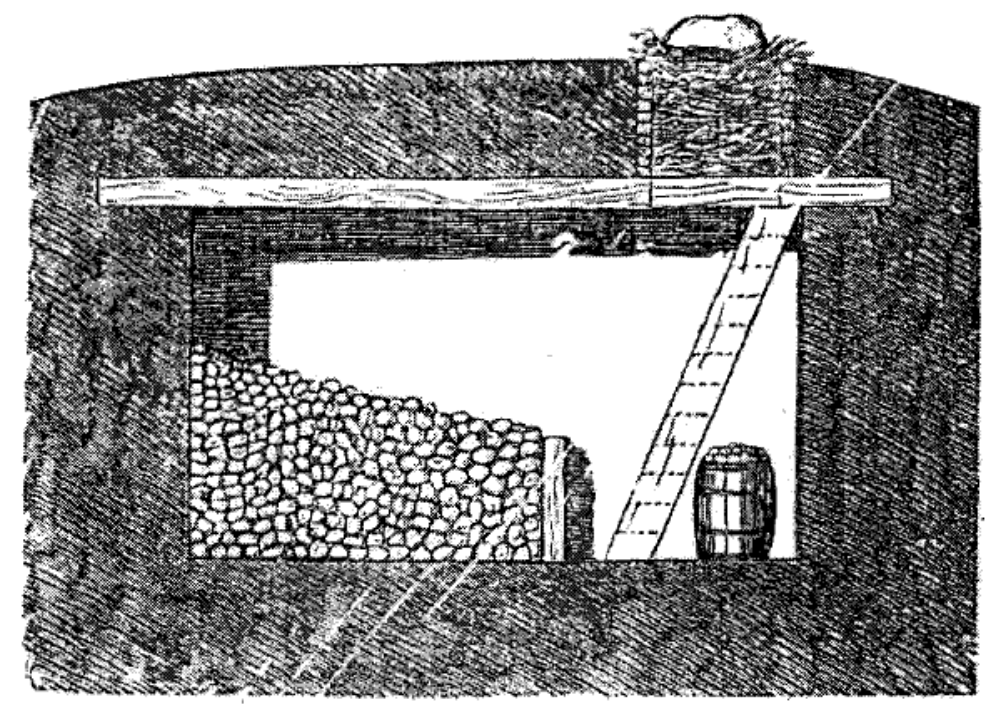

Figure 10. Field or prairie root cellar, built entirely underground (Gage 2009, 89).

Earthen-mounded cellars (Figure 11) used dirt as the primary insulator. An earthen-mounded root cellar maintained proper humidity and temperature more effectively than structures using other materials. A cellar structure covered in dirt is an earthen-mounded cellar. These cellars could be on level ground or partially submerged in the earth. Commonly these cellars were long and fairly narrow, with arched or stacked roofs. Construct- 
ing the cellar was accomplished with materials readily available, but the walls and roof had to be structurally sound enough to support the weight of the earth. Variations of this cellar had the roof partially or completely exposed. In general, roofs that were completely exposed were wood construction and partially covered roofs were concrete. Wood roofs covered in earth and sod had a lifespan of roughly ten years and then had to be replaced. Concrete roofs were usually thick enough to provide adequate insulation without having to be mounded entirely with earth (Gage 2009).

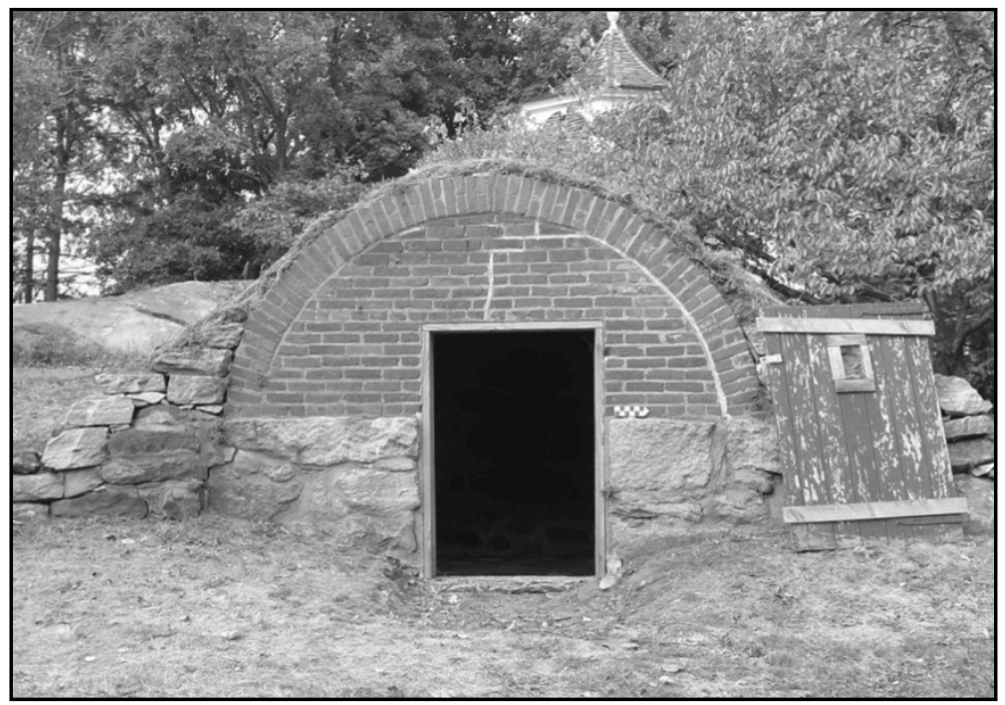

Figure 11. Example of an earthen-mounded cellar (Gage 2009).

Embankment, or hillside, cellars were dug into a hillside, allowing the earth to insulate the walls and roof (Figure 12). If topography allowed, this type of cellar was ideal. The entire structure benefited from the earthen insulation and if the soils were thick enough, the walls could be left as exposed dirt with a lime-mortar wash to prevent water seepage. 


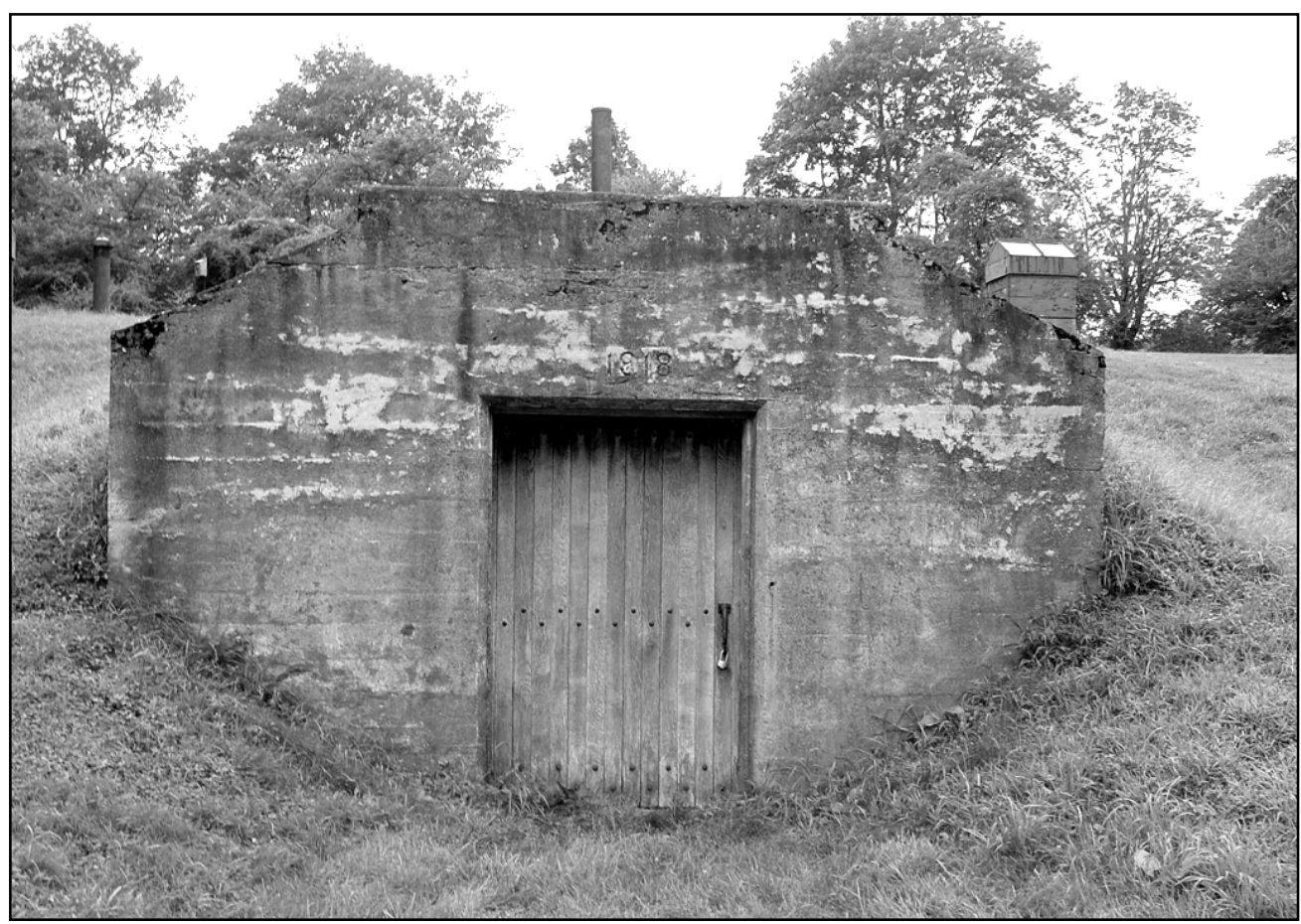

Figure 12. Example of an embankment cellar (Gage 2009).

Most embankment cellars, however, had walls to prevent earth from caving into the cellar and were built of wood, dry stone masonry without mortar, or stones set in mortar, brick, or poured concrete. If the cellar was deeply dug into a hillside, the roof needed to support the weight of the earth. Roofs could be flat, arched, or gabled and, like the walls, made of wood, brick, stone, or concrete. Constructed walls in hillside cellars acted as retaining walls to keep dirt and water out of the cellar. Typically the entrances were situated at a level grade, but some had steps down to the storage room. Embankment cellars could be entirely or partially built into a hill (Gage 2009).

A frequently seen variation of the earthen mounded and embankment cellar types was construction of an additional building over the storage area. Doing this was similar to adding a cellar under a house or barn, but differed in that the combined structure was planned, designed, and built around the requirements of cellars. The November 1895 issue of the Virginia Agricultural and Mechanical College Bulletin reported on the newly designed and constructed cellar with a storage room above. To the author's knowledge, this type of structure had never been built or documented, although "we once heard discussed but had not seen carried into practice" (Alwood 1895). The article exhibits a well-thought-out 
design and illustrates the growing importance of well-planned farms and outbuildings.

Detailed drawings show a sophisticated plan, including drainage and ventilation systems as well as allowances for loading and unloading carts and wagons (Figure 13). The ventilation system was optimized for the proper amount of air flow to keep vegetables. Likewise the drainage system in the cellar is well developed, as is the drainage around the structure. Because the cellar is dug into an embankment, the builders considered the drainage patterns of the site and shaped the ground to direct water away from the structure. After cellar construction, experiments were carried out that documented the expected temperature ranges and estimated crop storage lengths of the given factors. Experiments of this nature had seldom been published in the late 1800s. Seemingly the cellar type was unique to the region because of the author's statement of originality, although documentation from

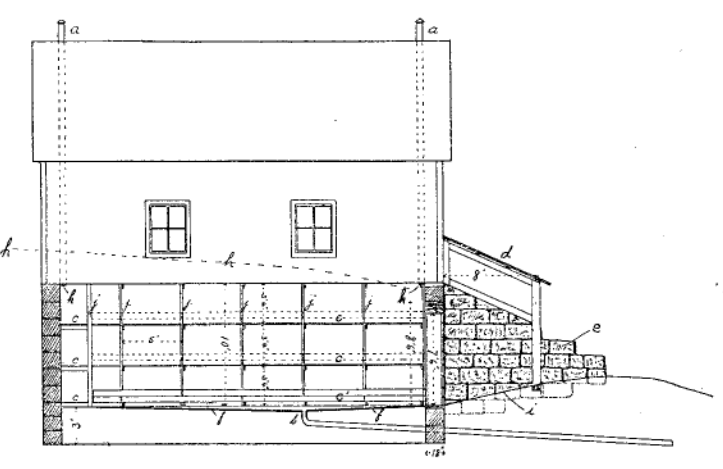

Fig. 1. Longitudinal Section

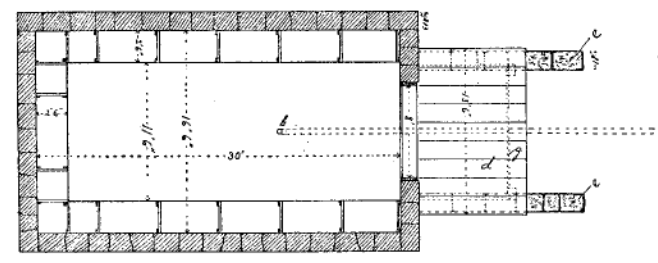

Fig. 2 Ground Plan

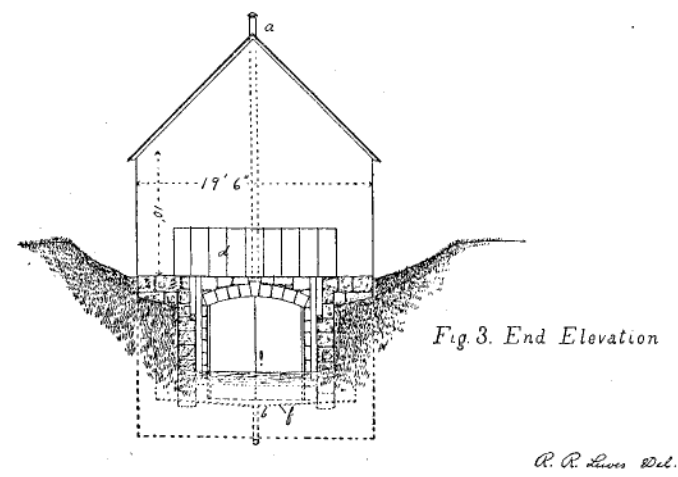

Figure 13. 1895 drawings for the "new plan for the construction of a storage cellar" (Alwood 1895). as early as the mid 1800s mentions examples of combining cellars with other outbuildings. It can be assumed a building combining a cellar in the foundation would be a practical alternative in building construction to farmers concerned with economies of space and labor (Alwood 1895). 
Although root cellars can be grouped according to five basic characteristics, there are multiple ways of constructing each type. Most often, cellar design was adapted in ways that took advantage of the surrounding environment. There were four primary factors in locating a cellar. The first priority was choosing a site in close proximity to the house. Storage cellars accessed daily during the winter needed to be situated near the residence. The second step was determining the most effective type of cellar for the terrain. The third consideration was to locate the cellar in a well drained area above the water table. Cellars had to stay dry; standing or seeping water as well as flooding could ruin the stored crops. The fourth consideration was orienting the entrance away from the prevailing winter winds and maximizing solar radiation. In general, this meant the entrance was on the south or east side of the structure (Gage 2009).

After the location of the cellar was determined, the construction materials were chosen; common choices were wood, brick, stone, and (after 1900) concrete. In addition to finding the appropriate site and available materials, the builder had to consider wall, roof, and floor designs; decide on an effective entrance system; and incorporate drainage and ventilation systems. Although a small structure on the farmstead, a storage cellar incorporated complex design and construction elements.

Among the five basic types of cellars, roofs were constructed in four basic designs: flat, gabled, slanted, and arched. Roof design was important in managing and directing water around the cellar. Flat, gabled, and slanted roofs were constructed with wood planks and joists, sapling poles, logs, or poured concrete. Arched roofs used bricks, stone blocks, or formed concrete construction. Gabled, slanted, and arched roofs shed water and were usually covered with one to two feet of earth and then sod. The benefits of these systems were increased water management and insulation (Gage 2009).

Floors in root cellars were commonly made of packed dirt. Earthen floors were effective in maintaining the proper levels of humidity in cellars and are the most common type of cellar floor used. As concrete construction became popular in the early 1900s, concrete floors were increasingly added because they could be cleaned easily. Cellar floors could also be made of unmortared bricks. Although uncommon, bricks laid without mortar allowed air to circulate between the bricks and under storage crates and baskets on the floor. The floor of a storage cellar should be level with the 
exterior ground. A level entry was the most efficient design for loading and unloading produce in the cellar. This could be accomplished easily with a single door system or with a double door and passageway system. On the other hand, some cellar entrance types had steps leading into the storage area. Steps, or stairs, made it more difficult to store and remove produce and were usually located outside the cellar. Leading down to an inner door in the cellar wall, the steps needed to be covered. Full height porches or a bulkhead entrance were the most common methods of protecting the stepped entrances. Placing and removing the stored produce was more difficult with steps, and subsequently these types of cellars might have a loading chute (Gage 2009).

The façade of the storage cellar could be brick, stone, or concrete with all or part of the wall exposed and not insulated with earth; wing walls extended beyond the width and height of the actual cellar to serve as retaining walls. Retaining walls might also be used leading to the entrance if the storage cellar was recessed further into a hillside. Cellars typically had a single, full-height door. A full-height door allowed ease of access and could accommodate small carts or other means of transporting stored goods. Other entry systems incorporated two-door designs, with outer and inner doors for more efficient insulation. Because of the buffer between the outdoor and indoor temperatures, the two-door system was preferred and recommended over the single-door system. Maintaining a constant temperature in a cellar was necessary for optimal storage conditions, so on extremely cold or hot days a cellar with a single door had to remain closed.

Storage cellars needed to be located in well-drained areas. To maximize storage length, root crops needed to be kept dry. Siting and construction methods like grading the land and using a gable, slanted, or arched roof were used to divert water away from the cellar. In addition to these techniques, in the early 1900s floor drains were added for drainage and also ventilation. The drain could be either a buried pipe extending from the middle of the floor away from the cellar or an opening at the end wall of the cellar. Drainage systems needed to be screened to prevent rodents from entering the cellar (Gage 2009).

In addition to adequate insulation and proper drainage, ventilation was critical in the long-term storage of root vegetables. During storage and especially in the weeks after harvest, root crops emit various gases. This was a recognized problem as early as the 1600 s, and root cellar designs tried to 
manage the off gases. One way of mitigating gases was to bury the food in an absorbent material. In subfloor pits, the roots were usually buried in sand to prevent the gases from entering the residence. However, as root cellars became larger, freestanding structures, methods of venting the gases were developed. Vents were also used to adjust the interior temperature and humidity of the storage cellar. The vents could be opened to draw cool air into the cellar or closed to insulate against warm air. To effectively ventilate a cellar, air must flow through it. Cross ventilation could be achieved through several means. A simple system consisted of two windows in opposite walls. This system was effective at circulating the air near the ceiling, but had little effect on the air surrounding storage bins near the floor. A more complex system drew air from around the door, through the length of the cellar, and then vented it out through the ceiling. In this system, storage bins needed to be located away from the walls and raised off the floor. Most root cellar constructions employed this type of whole-cellar ventilation system (Gage 2009).

Design and construction of successful root cellars prevented freezing, maintained a temperature between 32 and 40 degrees Fahrenheit, and vented gases and excess moisture for long-term food storage. If one of these systems failed, an entire season's worth of stored crops could be lost. Understanding environmental and site conditions facilitated locating the cellar in the appropriate place and determined the construction materials that would provide the most effective storage conditions (Gage 2009).

\subsection{Compare and contrast}

By the late 1800s, the most prevalent type of cellar in the Ozarks was the earthen-mound or embankment cellars. The Williams cellar exhibits characteristics similar to common embankment root cellar design and construction. However, the cellar varies significantly from the previously outlined, generalized cellar forms and types. The cellar is an example of Missouri Ozark farmstead outbuildings in its traditional siting, construction materials, and use. As an example of a vernacular farm outbuilding, the cellar exhibits the individual choices inherent in this type of construction. Most likely the cellar was constructed with available materials and without formalized plans. Moreover, Wesley Williams possibly enlisted family members and neighbors to help with the work, and so the structure also reflects their input and choices. In all, what is known about the cellar leads to a complex reading of the structure. On one hand, it is a prime example of root cellar construction, not only in the Missouri Ozarks but also 
on a national scale. On the other hand, there are variations that place it as a unique structure and an enduring remnant of the Williams' choices that incorporated unique regional and cultural contexts with a sophisticated environmental understanding (Pollock 1978) ${ }^{4}$.

The location of the cellar follows conventional siting practices. The front of the cellar faces southwest away from prevailing winds and would take advantage of any solar heat gain. Additionally, the cellar is located close to the main residence and built into the side of a hill. The northeast and southeast sides of the cellar are dug into the hillside making the cellar floor level with the sloping grade. The roof of the cellar, or the floor of the granary, was level with the top of the slope. Although the cellar is built on the slope of a drainage ditch, it was removed from the danger of flooding and water damage. The location of the Williams' root cellar represents practical cellar placement decisions not only among Missouri Ozarks settlers, but for anyone building a storage cellar. A unique variation in the location of the Williams' cellar is the public road that separated it from the house. However, given the other conditions of the site, the cellar was built in the most appropriate location, regardless of the road.

Perhaps because of the hillside slope, the Williams cellar is unusually oriented in the embankment. Typically, cellars extended lengthwise from the entrance with a narrower width. The Williams cellar reverses this by being dug shallowly into the hill with a longer width. In addition to the reversed orientation, the entrance configuration also differs from standard cellar types. Generally, the entrance to a cellar is centered in the front wall; the entrance to the Williams cellar is offset left of center. To the right of the door was where the storage bins and shelves were located (Figure 14).

\footnotetext{
4 The referenced journal Bittersweet was published by Ellen Gray Massey and her students at Lebanon (MO) High School between 1973 and 1983. The journal is available online at:

http://thelibrary.springfield.missouri.org/lochist/periodicals/bittersweet/index.html
} 


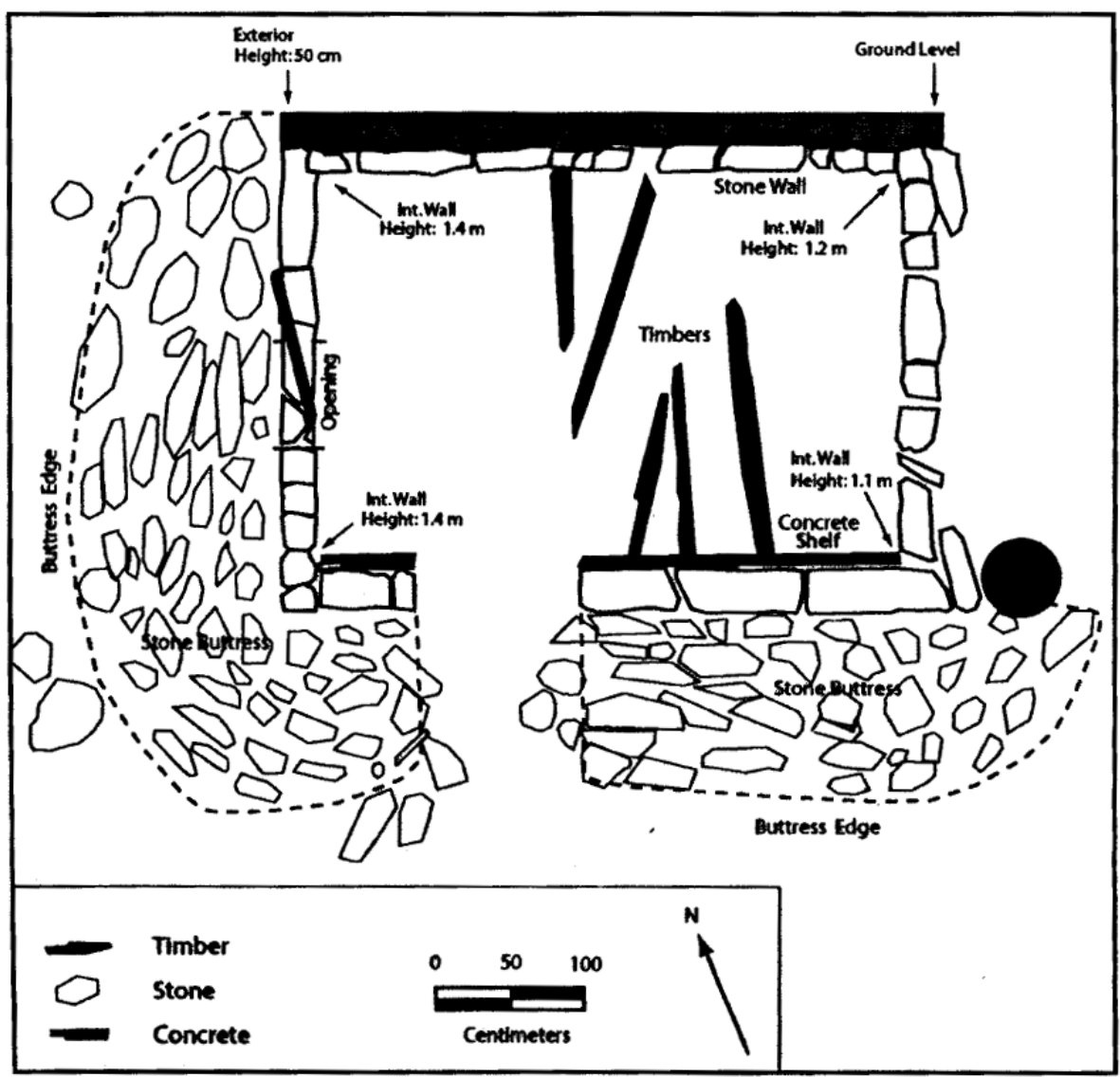

Figure 14. Williams site root cellar archeological investigation diagram, 2009 (ERDC-CERL).

The construction of the Williams root cellar is fairly representative of the area. The construction uses field stones, which were widely available and a high level of care was used to construct the walls without mortar. While stone walls for a cellar had to be thick, the walls of the Williams cellar are unusually thick. Because the cellar was the foundation for the above-level granary, the walls had to be buttressed to support the additional weight (Figure 15). Patsey Williams Niebruegge recalls the floor being concrete; however the concrete was probably added in the early 1900s. Not much is known about the ceiling construction, but it was likely insulated in some capacity. Additionally, not much is known about the granary aside from its post and frame construction. In the late 1800s and early 1900s it was fairly typical for cellars to be built in foundations of farm outbuildings. While there are no documented cases of cellar and granary combinations, the practice of combining a cellar with another building type dates back to the early 1800s (Ahler, et al. 2009).

The size of the cellar suggests that it was not only used for the family's food storage; it was also used as a storm shelter and had enough space for 
people to gather. The level entrance with the full-sized, single-system door made the cellar readily accessible.

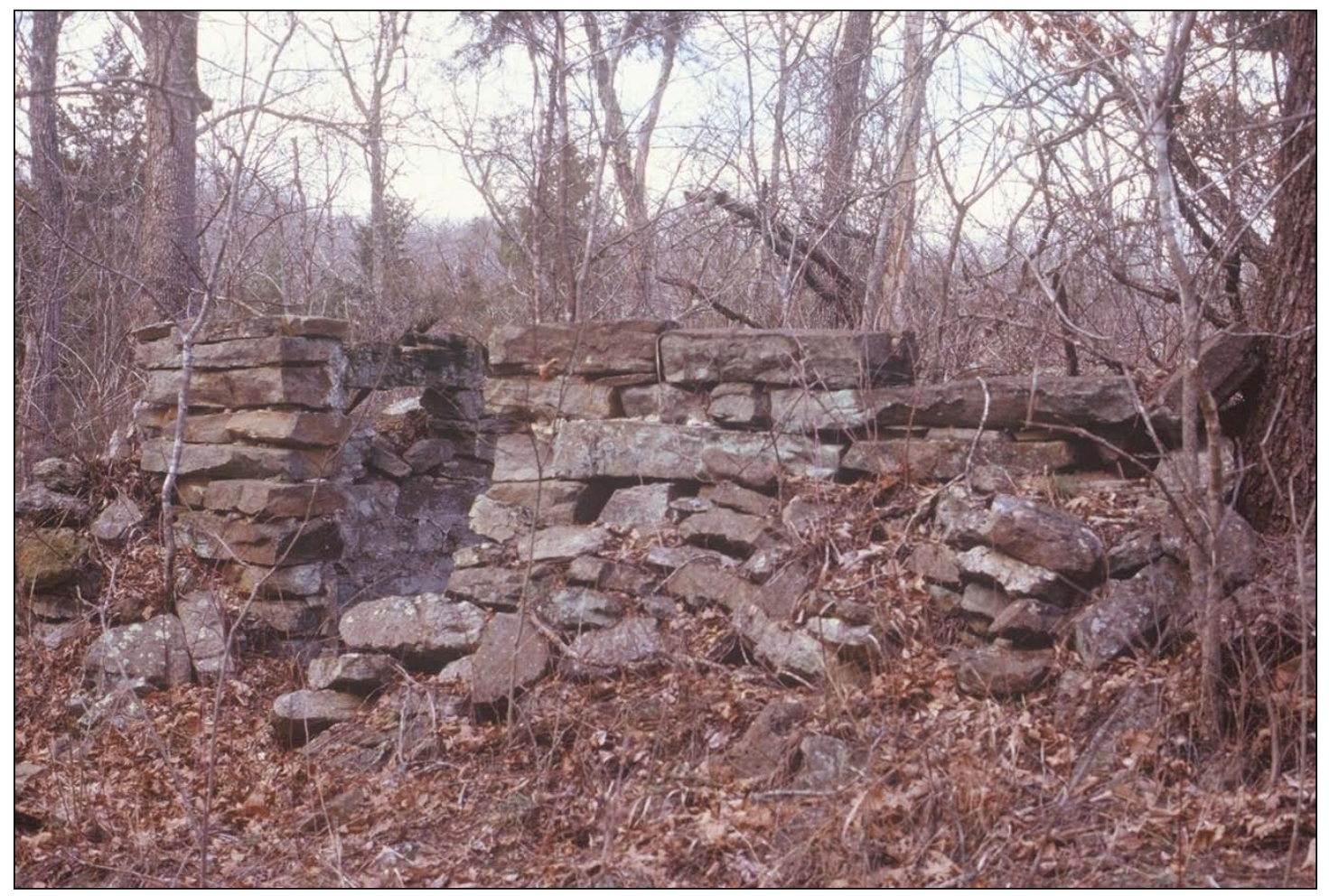

Figure 15. Buttressed stone walls of root cellar (23PU502), 2004 (ERDC-CERL).

\subsection{Conclusion}

The Williams root cellar is a suitable example of Missouri Ozark cellar construction. While there are variances not documented elsewhere, the basic factors in location, form, and use are typical. The Williams cellar is interesting in its combination of two types of storage structures, the cellar and the granary, which served several practical purposes in family life. It was made from locally available materials, and its design and construction styles were common in the Missouri Ozarks. However, combining cellars in the foundations of farmstead outbuildings was a fairly common practice nationally, and such cellars do not constitute a unique regional type to the Ozarks.

Ahler et al. concluded that 23PU502 was eligible for listing on the National Register of Historic Places. Though a well-preserved example of an earlyto-mid-twentieth century root cellar, the research for the effort reported here does not find that this root cellar adds to the strength of Ahler et al.'s conclusion under Criterion $\mathrm{C}$ (distinctive design or construction). 


\section{Results of Archaeological Investigations at 23PU508}

While the other sites investigated archaeologically and covered in this report were surveyed in October 2009, Site 23PU508 was surveyed on 21 January 2010, due to an inability to locate the site during the earlier trip. Though visited at a different time of the year, field conditions were remarkably comparable to the previous field session, with both trips being cold and damp.

\subsection{Site history}

The land surrounding 23PU508 was first platted by William Williams, who claimed 80 acres in the area of the site in 1859. He appeared to still be living and farming there in 1870, when he and his wife, Olive, and four children were recorded in the federal census (U.S. Bureau of the Census 1870). The only available map dating to that period, the 1873 Shumard map (Broadhead et al. 1873), generally does not show individual habitations and so does not corroborate occupation of the site during that time.

Adams (2003) notes that the 1906 Pulaski County map shows a residence near but south of the site, marked as being owned by a "W. Pippin. " There are no W. Pippins listed as residing in Roubidoux Township in either the 1900 or 1910 federal censuses, though a William J. Pippin and his family lived in Cullen Township (north of Waynesville) in 1900, and a George W. Pippin and family lived in Liberty Township in 1910 (U.S. Bureau of the Census 1900, 1910).

In 1930, the land was owned by J ames Alfred Abbott (W.W. Hixson \& Co. 1930), a West Virginia 5 native whose household included his wife, Martha J ane Abbott, son Aubrey E. Abbott, and grandson Elemer Williams (State Historical Society of Missouri 2010; U.S. Bureau of the Census 1930). $\mathrm{J}$ ames Abbott stopped farming the year of the census and passed away in 1932. His death certificate was signed by Dr. C. Mallette, who owned the farmstead that is now site 23PU510 (as documented in Section 7 of this report) (State Historical Society of Missouri 2010). The Abbotts appear in

\footnotetext{
${ }^{5}$ The census and death certificate list Mr. Abbott's birthplace as "West Virginia," though at the time of his birth (1858) it was still part of the Commonwealth of Virginia, becoming a separate state in 1863.
} 
the 1920 census for Piney Township as well, albeit with a different assortment of children and grandchildren (U.S. Bureau of the Census 1920).

The 1937 tourist map of Pulaski County shows no indication of there being a residence at the site, since it shows the nearest buildings being part of the Civilian Conservation Corps camp nearby along Missouri Route 17 (the Houston Road). The 1944 map of the area is similarly devoid of indications of human habitation at the location of Site 23PU508.

The 1948 real estate map for Fort Leonard Wood identifies the tract of land containing the site as being formerly under the ownership of Charley C. Woody and his wife. The 1920 federal census for Pulaski County lists one Charley Woody, a farmer, in Pulaski County (U.S. Bureau of the Census 1920). This Charley Woody was born in October 1896 in Missouri and married Mary Ethel Bailey (b. Pulaski County 1897) in 1915 (Reierson 2010b). They bore six children together (Reierson 2010a). Following their displacement by the Army, the family moved to west Hazelgreen, in neighboring Laclede County. Ethel passed away there in 1951 of heart failure (State Historical Society of Missouri 2010). Charles remarried in 1953, fathered one daughter, and passed away in 1965. He is buried in Lebanon Cemetery, Lebanon, Missouri (Reierson 2010a), the same cemetery where Ethel was buried (State Historical Society of Missouri 2010).

\subsection{Previous fieldwork}

Adams (2003) states that 23PU508 was first reported to the Archaeological Survey of Missouri in 1994 by Richard Edging and Curt Rankin, while working with the Center for Environmental Management of Military Lands (CEMML) at Fort Leonard Wood. They recorded only that there was a sandstone house foundation with associated cellar and well. When Adams and a PSAP crew returned to the site in 2003, they made a more detailed inventory of features and artifacts at the site.

The PSAP inventory of the site included the excavation of four shovel test pits, all of which were screened, but none of which yielded artifacts. Indeed, no artifacts were recovered from the site. Seventeen artifacts, consisting of a soda bottle base, one Albany-glazed stoneware crock fragment, five bricks, and ten metal fragments (non-military), were seen lying on the surface but were not collected (Adams 2003). 
Adams created a map of the site showing its two cellars and an intervening mound of broken sandstone and concrete, and an adjacent concrete pad with galvanized metal pipe. Several small spoil piles are present north of the site. The shovel test locations straddle the site at the cardinal directions (Adams 2003).

Based on the presence of Albany-glazed stoneware, Adams suggested that 23PU508 represented a late-nineteenth to early-twentieth century occupation with an overlying, more recent, disposal episode indicated by the scatter of metal cans. Given the site's isolation and apparent low degree of disturbance, Adams suggested the site could be considered eligible for the National Register of Historic Places (Adams 2003).

\subsection{ERDC-CERL fieldwork}

As with the other sites reported in this document, the first fieldwork task included a walkover of the site and its immediate environs. Features identified by previous archaeological surveys were relocated, and additional site features were noted. In this case, northeast of the homestead was an area covered in inland sea oats (Chasmanthium latifolium), which is a plant frequently seen on historic farmstead sites at Fort Leonard Wood (J oe Proffitt, personal communication to authors). Southwest of this patch of sea oats is an area of heavy disturbance, which is likely the result of recent earthmoving activities. The road running next to the site, visible in Figure 16, is in active use for military training, as troops were being taught to drive large trucks (M35 2.5-ton cargo trucks) on it during the fieldwork. The disturbance to the southwest end of the site and the scatter of modern material (plastic bottles, recent metal beverage containers) bespeak the threat to the site occasioned by its proximity to training activities. Recent earthmoving activity is not the only threat to the site. A gully running along the south side of the site is causing extensive erosion on the south side of the site, making a natural boundary for the walkover survey.

Before shovel testing, the ERDC-CERL archaeologist conducted a walkover survey of the site. A dense scatter of historic materials overlaid the visible cellar depressions noted by Adams in 2003. A representative sampling of the material present on the surface was collected. This included two pieces of milk glass lid liners from glass storage jars, one piece of animal bone, six pieces of refined earthenware, one brown-slipped earthenware, one clear glass bottle with neck decoration, one cobalt blue bottle, and one large panel bottle marked "TONIC/ VERMIFUGE” on the face and 
"PHILADELPHIA" on one side and "DR. D. JAYNE'S" on the other (Figure 17). Other artifacts including two large iron cans, one large plain stoneware crock, and other similar materials, were noted but not collected.

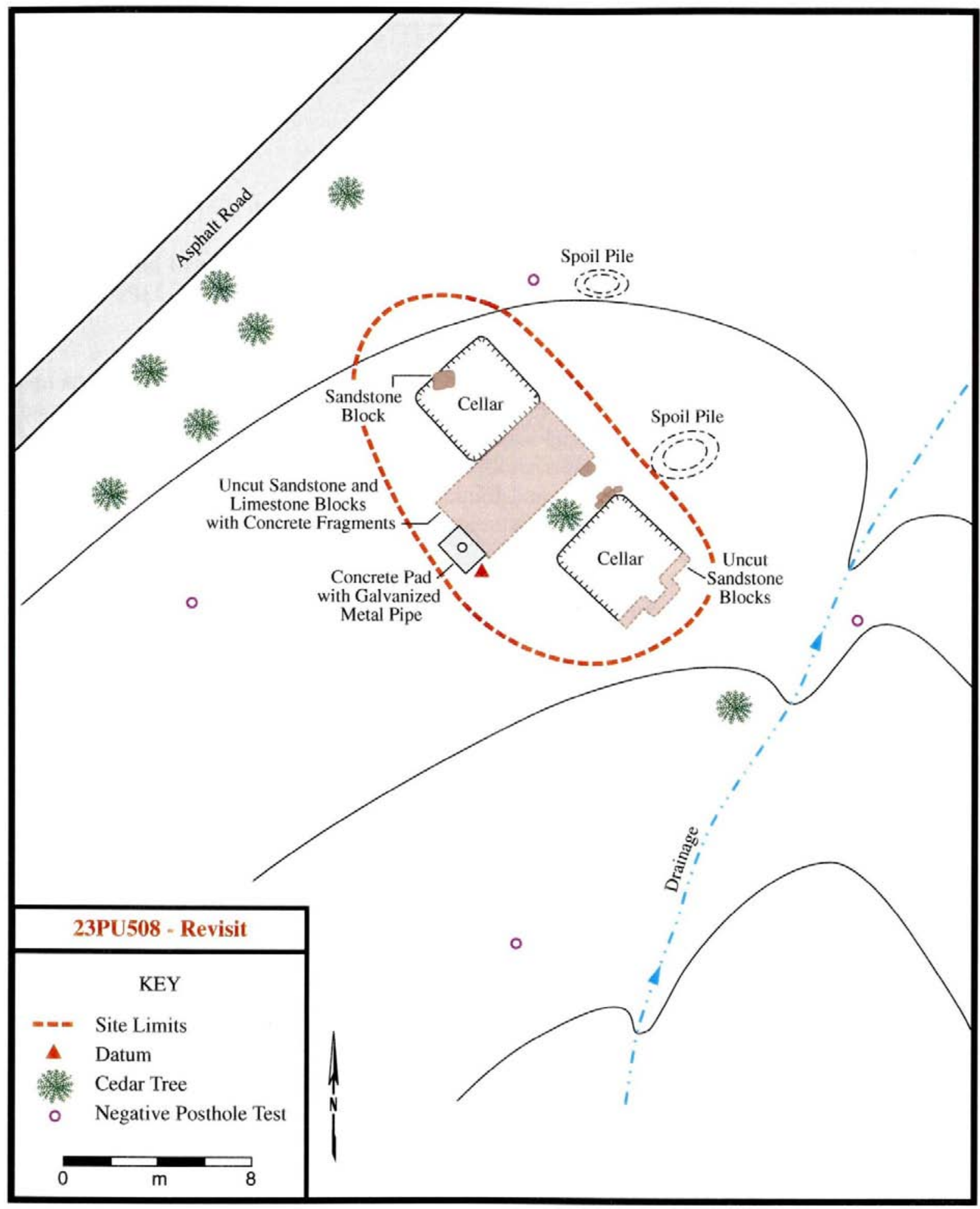

Figure 16. Sketch map of 23PU508 (Adams 2003, 66). 


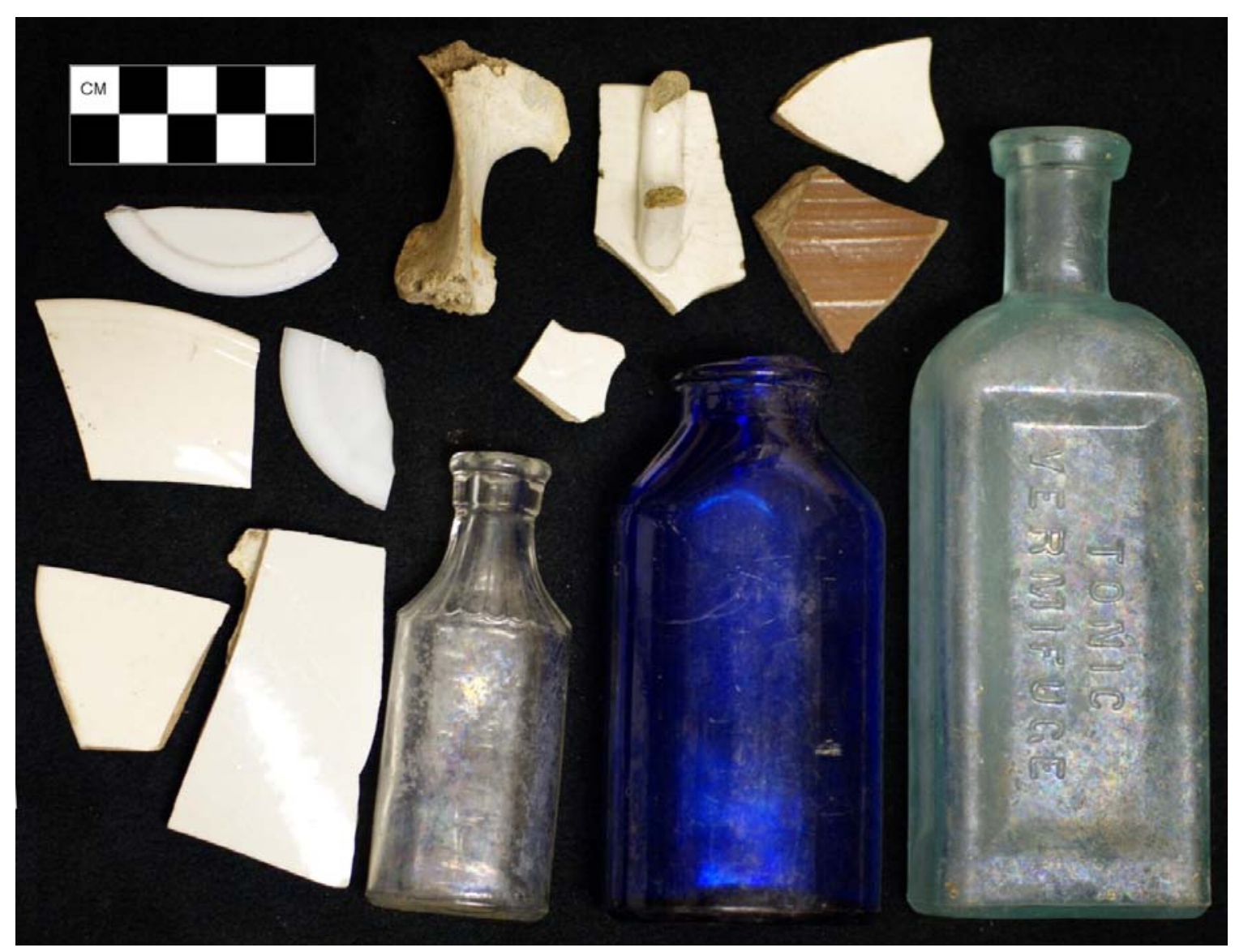

Figure 17. Artifacts from surface, 23PU508 (ERDC-CERL).

Two shovel tests were excavated at the site. The first was located in the floor of one of the depressions at the site, and the other was adjacent to the site. The first shovel test measured $33 \mathrm{~cm}$ across and was dug to a depth of $9 \mathrm{~cm}$ below surface (cmbs). From $0-4 \mathrm{cmbs}$ was a rich black (5YR2.5/1) loam, which contained one brick fragment. The next stratum started at 4 cmbs but encountered groundwater at $9 \mathrm{cmbs}$ (the site had been saturated by recent rains). The second stratum was a very dark brown (10YR2/2) clay loam. No artifacts were recovered from this stratum.

The second shovel test, as stated in the paragraph above, was located outside the immediate site's footprint. It was noticeably drier than its predecessor. Its overall dimensions were $34 \mathrm{~cm}$ across and $24 \mathrm{~cm}$ deep. It contained one stratum that terminated in a layer of local chert, which is a kind of stone common to the area. The chert layer did not appear to be a pavement or other kind on intentionally created surface. The single stratum was a dark reddish brown (5YR2.5/2) clay loam. It contained two wire nails and one large, flat piece of iron. 
The site was mapped using a Trimble GeoXH GPS, supplemented by a hand-drawn sketch map. Satellite availability was excellent on this trip, particularly in comparison to the October 2009 fieldwork, when poor satellite coverage was a main contributor to the difficulty in locating the site.

\subsection{Artifact analysis}

The tonic/ vermifuge bottle (Figure 17) was manufactured around 1894 and would have originally contained a patent medicine intended to rid the body of worms. This could be evidence of a medical condition suffered by one or more of the occupants of the site, one treated with medicine available from a popular, nationally known source. Dr. David J ayne was a prominent vendor of such medicines, opening business in the 1830s and operating from a store on Chestnut Street in Philadelphia, Pennsylvania. J ayne's company sold a number of different medicines including alteratives, carminatives, liniments, vermifuges, and expectorants (Fike 1987).

The white milk glass, lid-liner fragments in Figure 17 are from Mason jar lids. Such lid liners were patented in the 1860s and were a major development in home food preservation technology. The glass kept the contents of the jar from contacting the zinc cap, which would otherwise impart an unpleasant, metallic flavor to the food (Lindsey 2011). They remained in use until the 1950s, at which time the development of prepackaged food and proliferation of plastic packaging edged out home canning.

The blue bottle (Figure 17) gets its color from the addition of cobalt during the glassmaking process. It is a straight-sided bottle with what J ones and Sullivan (1989) would describe as being "ovoid with flat sides" in cross section. Fike (1987) terms bottles with such cross sections as "salamander oval" bottles. These bottles are common on historic sites, and are most frequently associated with popular medicines, such as Bromo-Seltzer and Milk of Magnesia, both antacids. This example once contained the latter, bearing a base stamp reading "GENUINE/ PHILLIPS/ MADE IN U.S.A." along with an "M" and a "19." Bottles bearing an "M" as a maker's mark were produced by the Maryland Glass Company of Baltimore. The lack of a circle surrounding the "M" indicates it was made between 1907 and 1916, when the company adopted a circled "M" as a trademark (Toulouse 1971). The lip of the bottle is broken off, which makes it impossible to tell whether there was a cork or screw-cap closure. 
The small, colorless glass bottle with a fluted shoulder (Figure 17) is a medicinal bottle. It is graduated in cubic centimeter (cc) measurements on one of its flat sides for measuring doses. Mold seams on the bottle run around the base and up both sides to the lip, indicating it was made in an automatic bottle machine; this information would date it definitely after 1904, though likely after 1920 (Miller 1984; Newman 1970).

The six fragments of refined earthenware shown in Figure 17 include five whiteware rim sherds and one ironstone body sherd. The five rim sherds include three flatware sherds and two hollowware sherds. Two of the three flatware sherds are undecorated, and the third is stamped with a feather design. The two hollowware sherds come from different vessels-one from a bowl and one from a cup. The bowl fragment has a lipped rim. The cup fragment includes the base of a handle and lacks any rim treatment. Whitewares in the United States date to the period after 1830 (Miller 1991).

The lone body sherd is a fragment of an undecorated white ironstone vessel of large size and thickly potted. It has a very white paste with a thick slip on its interior, which is densely pockmarked. It has a white glaze, which has a slightly bluish cast to it. Such wares were made in England and imported to the United States starting in the 1840s. They remain in use and development today (Miller 1991).

The remaining ceramic fragment is a small sherd of Albany-glazed stoneware. Identified by its characteristic brown color, this sherd's glazing takes its name from the city in New York that was well known for exploiting local clays to produce a slip with that characteristic color. It was widely used during the nineteenth and twentieth centuries (Ahler et al. 2009).

The bone fragment is from an indeterminate mammal of moderate size (Figure 17). Further analysis would likely be able to identify the species from which the bone originates. It does not appear to have been deliberately sawn or hacked, which would be an indication that it was from an animal used for food by the occupants of the farmstead. It is possible that the bone was recently dropped by a forest predator, or it is the remaining element of an animal that died of some other cause at or near the site. 


\subsection{Site description}

Unlike the other sites visited during this project, 23PU508 appears to have significant evidence of recent visitation and disturbance by visitors to the area. The proximity of the site to the road, and the clarity with which site features (two large cellar holes) could be recognized, are likely to draw visitation. However, there was no evidence observed during the field visit of looting of the site (no evidence of illicit excavation). Rather, disturbance appears to be either earthmoving or the deposition of modern trash on top of the artifacts visible on the surface.

The artifacts from the site point to a late-nineteenth or early-twentieth century occupation, with numerous artifacts dating to the early decades of the twentieth century. English ceramics and bottles from large cities along the eastern seaboard indicate that even though this farmstead was nestled deep in the Missouri Ozarks, it was by no means isolated from the global trade networks of the period.

The farmstead itself consisted of at least a house with at least one underfloor cellar. Four dressed stones laid out in linear fashion along the west side of the site are likely piers that once supported the house itself. A potential fifth pier lies to the east of the cellar holes. These piers were not noted in prior fieldwork.

The two cellar depressions, referred to as Structures A and C in Adams (2003), each measure $4 \mathrm{~m}^{2}$. The southeast cellar depression (Adams's Structure A) is lined with undressed stone blocks, which are not in evidence in the other cellar depression. Between the two lies a jumbled pile of stone blocks (Adams's Structure B), at the west end of which lies a pipe fixed to a cement pad, which is likely a well. Structure B measures approximately $3 \times 6$ m.

Adams noted the presence of two potential spoil piles northeast of the site. These were not observed during the 2010 fieldwork. 


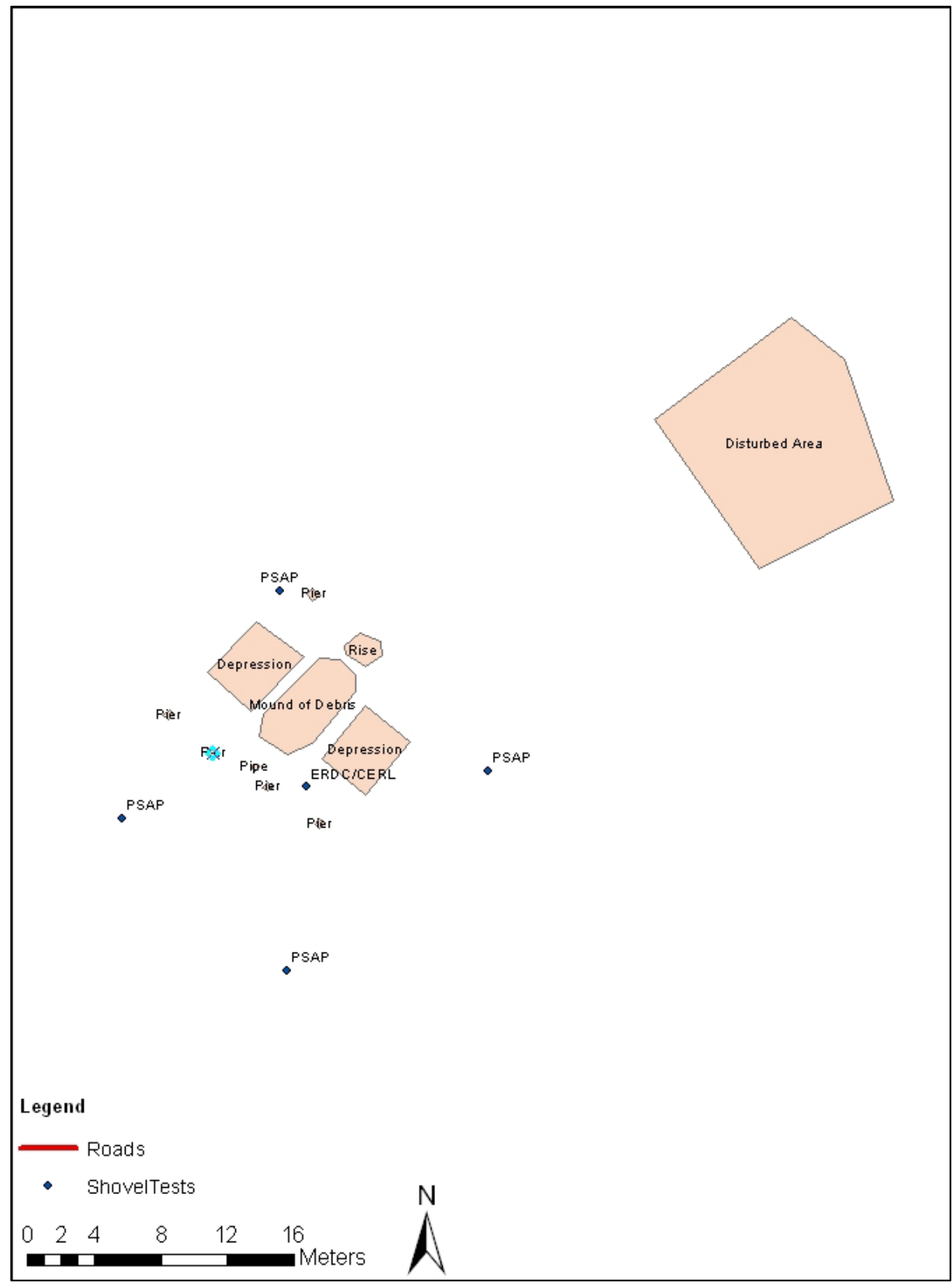

Figure 18. Site map of 23PU508 (ERDC-CERL).

Adams redefined the site area from the $50 \times 50$-m outline established by Edging and Rankin to a smaller 15 x 15-m area, which essentially borders 
the cellar depressions (Figure 16). This is too restricted of a boundary to encompass the farmstead as it likely existed during occupation. Though PSAP's shovel tests were negative, there are other evidences for human use and alteration of the area outside the site boundaries established by Adams. The area of sea oats lying northwest of the farmhouse remains is likely due to activities stemming from the habitation of the site. The quotidian activity space of the farmhouse would have to have been more expansive than the present site boundaries, and a readoption of a site size commensurate with Edging and Rankin's estimation of the site is warranted.

The site lies in the southwest quarter of the northwest quarter of Section 28, Township 34 North, Range 11 West.

\subsection{Conclusion}

Adams (2003) suggested the site was eligible for listing on the National Register of Historic Places based on Criterion D (potential for containing scientific data). This round of fieldwork suggests little to contradict that assertion, given the apparent intact nature of archaeological deposits at the site. There has been recent disturbance to the northeast edge of the site, but not to the area around the house proper because it appears to be unharmed. 


\section{Results of Archaeological Investigations at 23PU509 (Bryun L. Christeson Site)}

\subsection{Site history}

The land on which 23PU509 sits was first claimed by Alfred M. McElroy of Pulaski County in May of 1857 in a patent of 80 acres (Bureau of Land Management 2010). Alfred McElroy appears in census records for Pulaski County as early as 1840 and as late as 1860 (U.S. Bureau of the Census 1840, 1850, 1860). McElroy was born in 1795 in South Carolina. His four land patents are dated 1843, two in 1857, and one in 1860 (Bureau of Land Management 2010). The 1843 patent is for land near the site location. It may be that the McElroy homestead was located at this other location, and the area around 23PU509 was merely farmed, not inhabited, at that time.

The 1873 Shumard map of Pulaski County shows the area around 23PU509 as being "broken country" bordering "Robidoux [Roubidoux] Creek". No habitations are noted at the site, though two star-shaped notations to the south and southwest may indicate structures or small settlements.

The 1906 map of Pulaski County shows the area of the site as being free of habitation and essentially the terminus of the road coming south from the Dundas schoolhouse (23PU284, Section 3 of this report). The 1930 plat of Pulaski County shows the site area as being on the border between the lands of L. Stockdale and O. Laughlin (W.W. Hixson \& Co. 1930). An Orville Laughlin resided in Cullen Township, Pulaski County, in 1930, and he may have owned the land near the site at the time (U.S. Bureau of the Census 1930). “L. Stockdale” may refer to Linza (Linsey) Stockdale, who along with his small family resided in Roubidoux Township in 1920 (U.S. Bureau of the Census 1920), but by 1930 had relocated his family to Salem Township, Ohio (U.S. Bureau of the Census 1930). Given the roughness of the 1930 plat map, it is difficult to determine with great certainty whose land 23PU509 sat on, though it would appear Orville Laughlin is the more likely candidate.

The tourist map of Pulaski County produced in 1937 shows no structure at the site, noting only the Dundas schoolhouse (23PU284) in the vicinity. 
The 1944 map of Fort Leonard Wood shows no clear denotation of a structure at the site, but a small road spurring off from the main road could be in the immediate vicinity of 23PU509.

The final cartographic reference to 23PU509 comes in the 1948 real estate map of Fort Leonard Wood. The claim for the land where the site sits went to Bryun L. Christeson. Members of the Christeson family were among the first American settlers in Pulaski County, though an extensive search of the U.S. census data failed to identify a single Bryun Christeson to match the Army's real estate map. A Byrum Christeson (b.1904, d. 1970) was identified during the search, and this may be the individual who held the claim. Byrum Christeson lived in Roubidoux Township in 1930 (U.S. Bureau of the Census 1930), and passed away in Crocker, Missouri, in 1970 (Social Security Administration 2010).

\subsection{Previous fieldwork}

The site was first reported to the Archaeological Survey of Missouri in 1994 by staff from Fort Leonard Wood (Kreisa et al. 1996). It was revisited in 1995 in conjunction with PSAP's survey of the McCann Cemetery Tract. PSAP archaeologists made a sketch map of the site, conducted a pedestrian survey, and dug 12 shovel test pits, three of which contained artifacts (maximum depth was $23 \mathrm{~cm}$ ) (Figure 19). PSAP noted the presence of "five brick fragments, a metal bucket, and one milk glass canning jar lid liner embossed with 'CAP'” lying on the surface (Kreisa et al. 1996). 


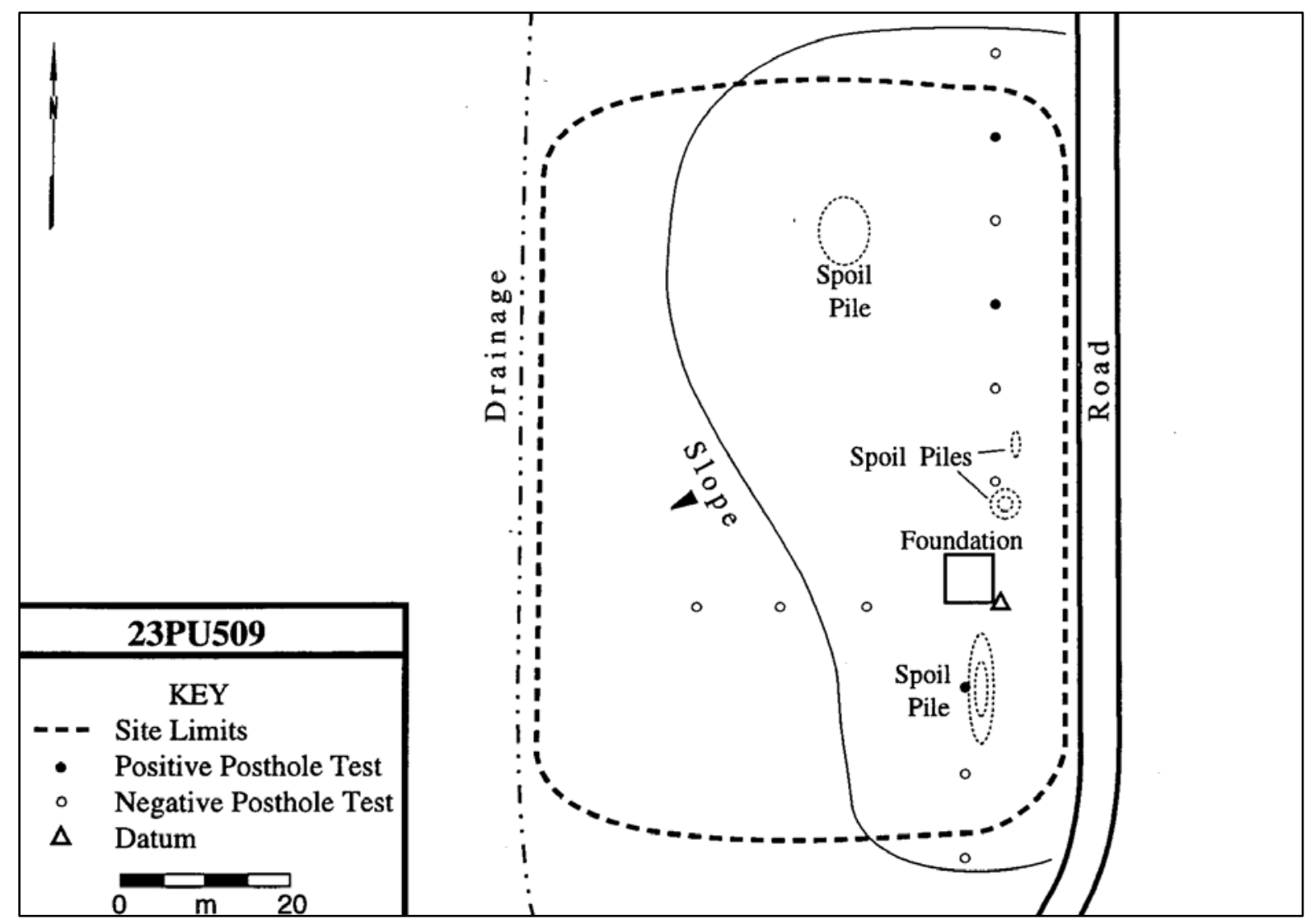

Figure 19. PSAP map of fieldwork at 23PU509 (Kreisa et al. 1996).

Historic artifacts recovered from the shovel tests at 23PU509 include "two can fragments, one piece of clear flat glass, one undecorated ironstone sherd, two undecorated whiteware sherds, one salt-glazed stoneware sherd with interior Albany slip, and one clear bottle (?) glass fragment" (Kreisa et al. 1996).

PSAP archaeologists also analyzed historic aerial photographs for evidence of the site and the period when it was occupied. They found that the site was visible on the 1938 and 1942 aerial photographs of the Fort Leonard Wood area, but did not appear on the 1948 Waynesville 15' quadrangle map (Kreisa et al. 1996).

At the conclusion of their project, PSAP recommended that 23PU509 be subject to Phase II excavations to make a final conclusion on National Register significance. The presence of salt-glazed stoneware suggested to them that there might be a post-Civil War component to the site, one predating the twentieth century concrete foundation currently visible, which 
could add to our understanding of the late-nineteenth century in the Missouri Ozarks (Kreisa et al. 1996).

\subsection{ERDC-CERL fieldwork}

ERDC-CERL archaeologists visited 23PU509 in October 2009 for shovel testing, performing a pedestrian survey, drawing a sketch map, and photographing the site. The pedestrian survey centered on the house foundation and radiated to a distance of $50 \mathrm{~m}$, although it did not cross the nearby road. Little cultural material appeared on the surface during said survey.

The first of the shovel tests (Shovel Test 1) was $2.5 \mathrm{~m}$ east of the southeast corner of the foundation (Figure 20). The soil strata here include a thin silty topsoil layer (10YR3/2) overlaying a silty clay stratum (10YR4/4). Below that lies the clayey subsoil (10YR5/4), at the shallow depth of $28 \mathrm{~cm}$ below surface. The shovel test pit held no artifacts.

Shovel Test 2 is approximately $3 \mathrm{~m}$ north of the foundation's north wall (Figure 20). Like Shovel Test 1, this pit also was shallow and bereft of artifacts. Again, a thin silty topsoil layer overlaid a silty clay stratum, under which lay clayey subsoil. Total depth for the shovel test pit was only $32 \mathrm{~cm}$ below surface.

Only two artifacts were seen on site other than the foundation walls. The first was a large metal wash tub approximately $15 \mathrm{~m}$ west of the southwest corner of the foundation (not shown on map). One metal can, likely a beverage container, was within the confines of the foundation. It is a pull-tab type opening, which were most popular between 1962 and 1972 (Busch 1981), and is, therefore, likely trash deposited by traffic passing on the nearby installation road. 


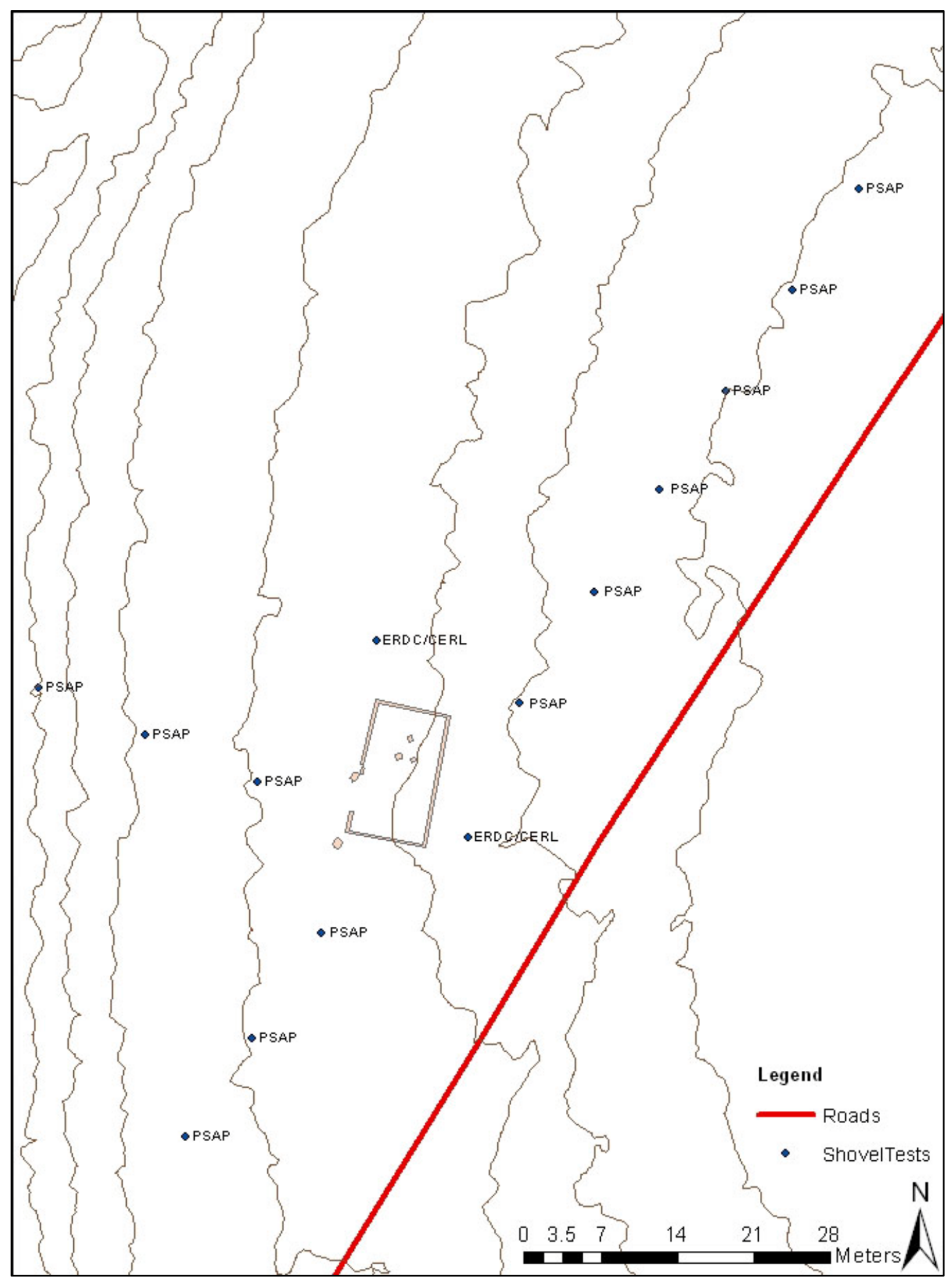

Figure 20. Site map of 23PU509 (ERDC-CERL).

\subsection{Site description}

The foundation itself has curtain walls made of poured concrete. Once rectangular, the northeast corner has been disturbed by subsequent tree 
growth and collapse. Near the north end of the west wall, a large field stone was made part of the foundation. Maximal height for the foundation is around $40 \mathrm{~cm}$ above surface. The spoil piles noted by Kreisa et al (1996) were not observed during the field visit.

The foundation itself measures approximately $7 \mathrm{~m}^{2}$ and is intact save for a portion of the east wall, which has been destroyed (Figure 20). There was no significant scatter of historic materials on the surface at the site, and only a few artifacts were recovered during subsurface testing, all of those having been found by PSAP in the 1990s. The site may have had a Civil War or postbellum component, based on the presence of salt-glazed stoneware at the site.

The site lies in the southeast quarter of the southwest quarter of Section 12, Township 34 North, Range 12 West.

\subsection{Conclusion}

23PU509 was likely a farmstead occupied sometime after the Civil War and up through the early twentieth century. The whiteware and salt-glazed stoneware suggest the possibility of a mid-to-late-nineteenth century component of the site. Predating the use of poured concrete foundations, this component would not be immediately visible aboveground and likely would require more extensive excavation to accurately characterize.

Kreisa et al (1996) deferred judgment on the potential eligibility of 23PU509 to the NRHP until after a proper Phase II survey of the site had been conducted. Based on this recent round of fieldwork, it would be hard to make a case for eligibility looking only at the early-twentieth century foundation, as the apparent lack of outbuildings or supporting structures (well, privy, etc.) suggest an ephemeral presence at the site. However, the possibility of there being an earlier component to the site, and the fact that it appears to have been only minimally disturbed since the 1940s, suggest the potential for the site having an earlier, mid-to-late nineteenth century component, which could still be intact and could be the basis for an argument for eligibility based on Criterion D. 


\section{Results of Archaeological Investigations at 23PU510 (Dr. C. Mallette Site)}

The Dr. C. Mallette Site differs from the others studied during this project. It was not an upland site as the others were, lying instead along the valley floor of Roubidoux Creek. It is also a larger, more complex site that contains structures not seen elsewhere during this research.

\subsection{Site history}

Daniel Bench patented the land in 1857 on which 23PU510, the Dr. C. Mallette Site, stands (Bureau of Land Management 2010). Bench arrived in Pulaski County some time before 1845, when his first land patent was issued. Coming from North Carolina, his family, along with those of several of his siblings and his parents, spent time in Bartholomew County, Indiana, before moving to Pulaski County in the early 1840s (Laclede County Genealogical Society 2000).

The Shumard map (Broadhead et al. 1873) does not indicate any habitation at the site of 23PU510; however, since it was a geological map, this fact is not remarkable because farmsteads were typically not recorded on it. Two larger structures, one labeled "Cook's Mill," are located to the south and southwest of the site.

The 1906 map of the area shows no evidence of there being habitations at the site, though it is possible the map is incomplete. The 1906 map shows a consistent distribution of houses throughout Pulaski County except for the area around 23PU510, 23PU509, 23PU511, and 23PU512. It is possible that this is due to a gap in the placement of houses that reflected the difficulty of traversing and settling on what Shumard referred to as "broken country." However, the course of Roubidoux Creek through this section of the map is unfinished, as is the lettering on the map name, which suggests that the gap is not in the distribution of housing itself but in its recordation on the 1906 map.

By 1930, S.M. York owned the land where 23PU510 stands (W.W. Hixson \& Co. 1930). This is likely Samuel Monroe York (b. 1870, d. 1934), hus- 
band of Elizabeth Thornsberry York (b. 1873, d. 1946) (State Historical Society of Missouri 2010).

The 1937 tourist map of Pulaski County shows no evidence of a farmstead at the site of 23PU510. The 1944 Fort Leonard Wood map does, however. The old road noted in the previous fieldwork (Section 7.2 below) that ran to the farmstead is clearly marked, as is the presence of a structure.

When the Army acquired the land at the onset of WW II, the site was owned by Dr. Cyrus Mallette, for whom it is now named. Dr. Mallette was a physician in Bloodland, who along with his wife Monta York Mallette, kept a house on Missouri Route 17 from before 1910 until 1922. Monta York Mallette was the daughter of the site's previous owners, Samuel and Elizabeth York; Monta and Dr. Mallette likely inherited the property upon the passing of one or both of her parents. In 1922, the Mallettes moved to Crocker, located in Tavern Township to the north of Fort Leonard Wood. Dr. Mallette continued to serve patients throughout Pulaski County through house calls until well after the fort was established (Nutt 2012). This begs the question of whether the site should more properly be considered a York homestead, as there is little evidence that Dr. and Mrs. Mallette ever lived there.

\subsection{Previous fieldwork}

23PU510 was first documented in 1994 by Fort Leonard Wood personnel. They noted the presence of a house foundation, cellar, five outbuildings, two concrete tanks, and two silos. Most of these structures could not be subsequently relocated (Kreisa and Adams 1999). Fort Leonard Wood archaeologists did make a map of the site, showing the relict road running to the site as well as numerous outbuildings to the west of the farmhouse that suggest the occupants of the site were engaged in fairly extensive agriculture, no doubt facilitated by the site's location on the bottomland along Roubidoux Creek (Figure 21).

Kreisa and Adams (1999) reported on PSAP investigations at 23PU510 during the 1998 field season. Plans to shovel test the site in the environs of the house foundation and root cellar were called off due to the site being overgrown with poison ivy. They mapped four features: the house foundation, the root cellar, one outbuilding, and the road that used to lead to the front (uphill side) of the house foundation (Figure 22). Other elements of the site, as previously identified by Fort Leonard Wood personnel, could 
not be located during the PSAP investigations due to the dense undergrowth covering the site (Kreisa and Adams 1999).

The PSAP crew recovered two artifacts from one shovel test " 80 m south of the southernmost outbuilding" at 23PU510. These consisted of one fragment of aqua bottle glass and a sherd of dark, nearly black, glazed earthenware. Due to the large size of the structure and its supposed association with Dr. Mallette, Kreisa and Adams suggested that 23PU510 was potentially eligible for the NRHP.

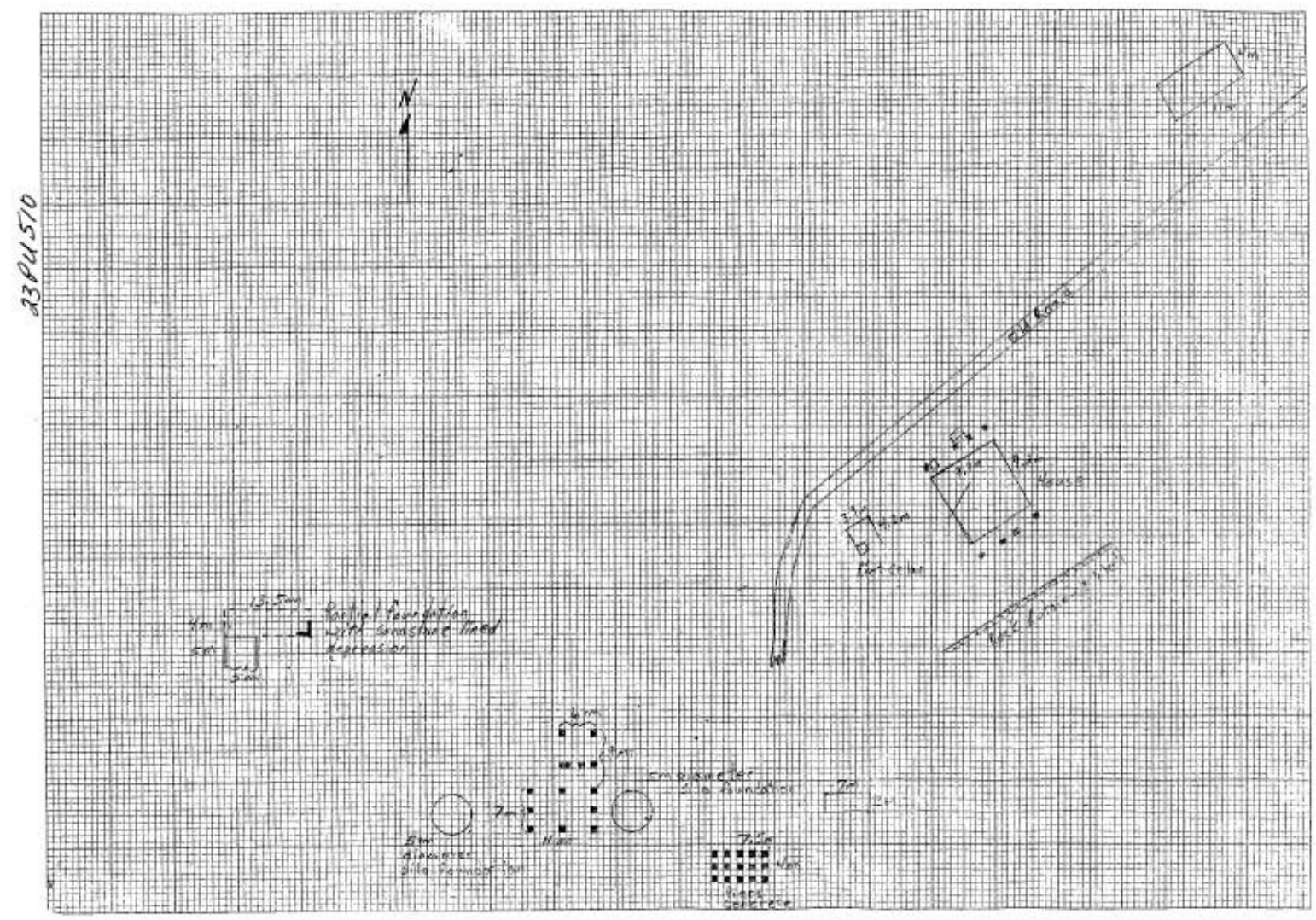

Figure 21. Sketch map of 23PU510 by Fort Leonard Wood archaeologists, 1994. 


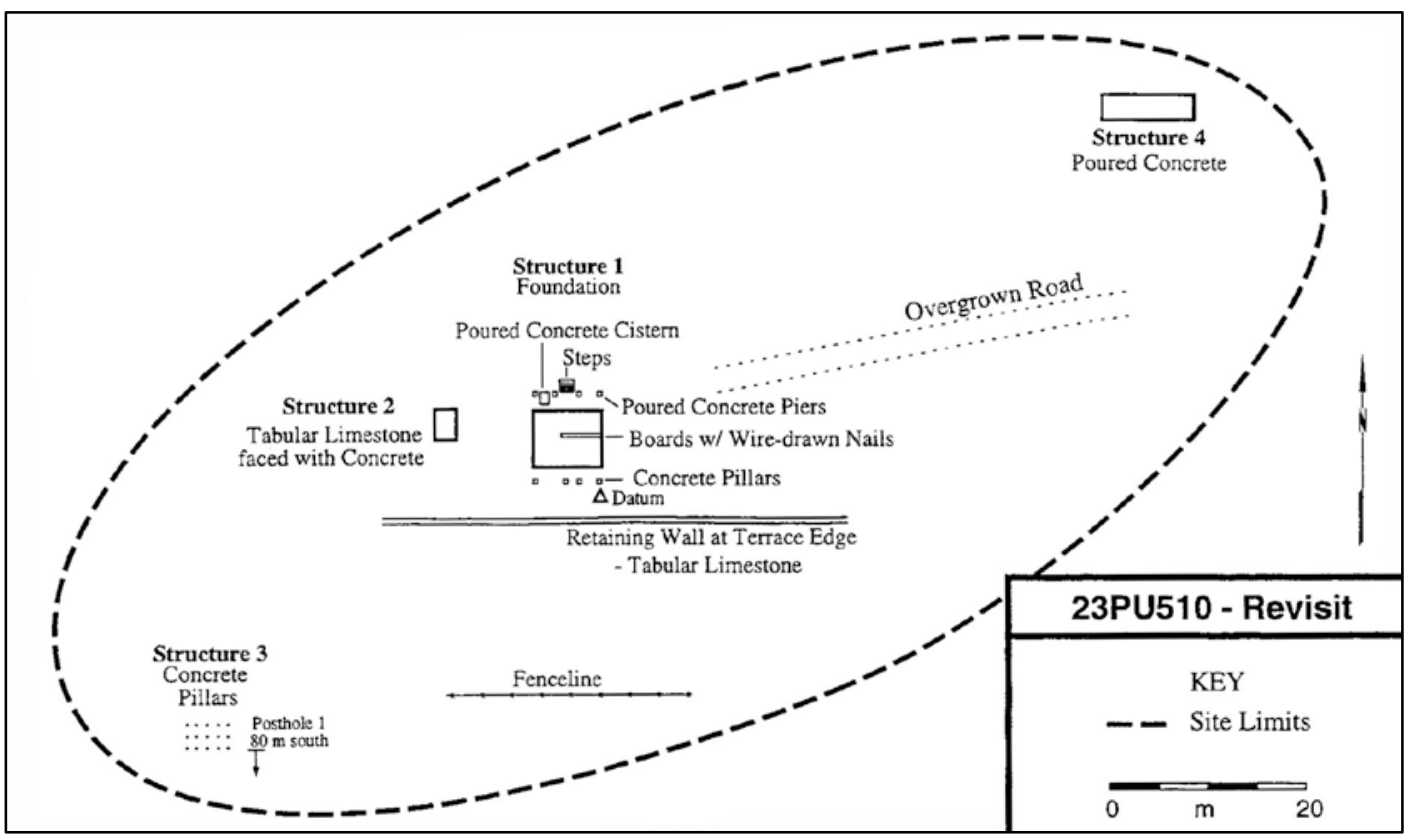

Figure 22. PSAP map of 23PU510 (Kreisa and Adams 1999).

\subsection{ERDC-CERL fieldwork}

ERDC-CERL archaeologists visited 23PU510 on 27 October 2009. Heavy undergrowth and substantial remaining tree canopy made locating the site through visual recognition difficult and interfered with efforts to acquire a GPS signal for mapping the site. When located, the site proved to be thoroughly overgrown by underbrush and small trees.

The site was mapped with a GPS, and the layout of the farmhouse foundation was sketched in the field book for subsequent refinement of the digital map of the site. The house foundation, stone-lined root cellar, well, retaining wall, and outbuilding foundation northeast of the house were readily located. Attempts to identify features noted in 1994 were frustrated by the dense undergrowth that has taken over the site.

Three shovel test pits were excavated. The first was excavated near the back of the house, close to the easternmost of the short pillars along the house's southeast face. The second was dug just north of the historic road across from the front of the house, and the final was dugjust west of the root cellar. All three shovel tests exhibited the same basic stratigraphy. A thin (1.5- $3 \mathrm{~cm}$ ) organic horizon (10YR2/1) overlay a thicker layer of silty clay (10YR3/2, 10YR4/3, and 10YR2/1). Underneath this layer lay a stratum of dark yellowish brown clay subsoil (10YR4/4 or 10YR5/4) containing a small amount of silt. The depth at which the subsoil was 
encountered varied, being shallower ( $12 \mathrm{cmbs}$ ) in the second shovel test and deeper (32 cmbs) west of the root cellar. Only Shovel Test 3, west of the root cellar, contained artifacts. This final shovel test pit (Shovel Test 3) was placed southwest of the root cellar in hopes of finding some material culture. In this instance, four artifacts were recovered. These consisted of two pieces of ceramic (one whiteware sherd, one brown-glazed earthenware sherd) and two pieces of iron hardware (Figure 23).

Following the mapping of the house site, root cellar, well, and outbuilding, an effort was made to locate the other structures noted by previous archaeologists. These structures included two silo footings and foundations for three other outbuildings. Two of the outbuildings had pier foundations, and the other manifested as a poured concrete foundation. Because of a lack of satellite availability due to the time of day, poor access to satellites under heavy forest canopy, and the thick undergrowth, these other features could not be located even after a prolonged search.

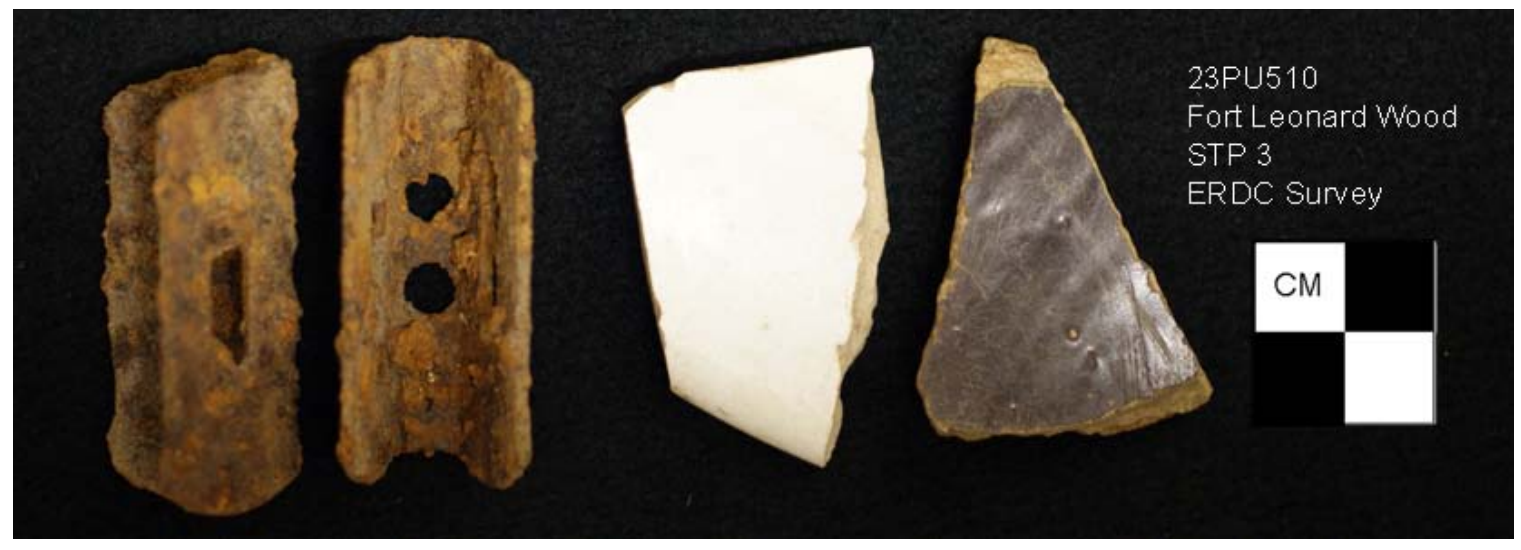

Figure 23. Artifacts recovered from 23PU510 (ERDC-CERL). 


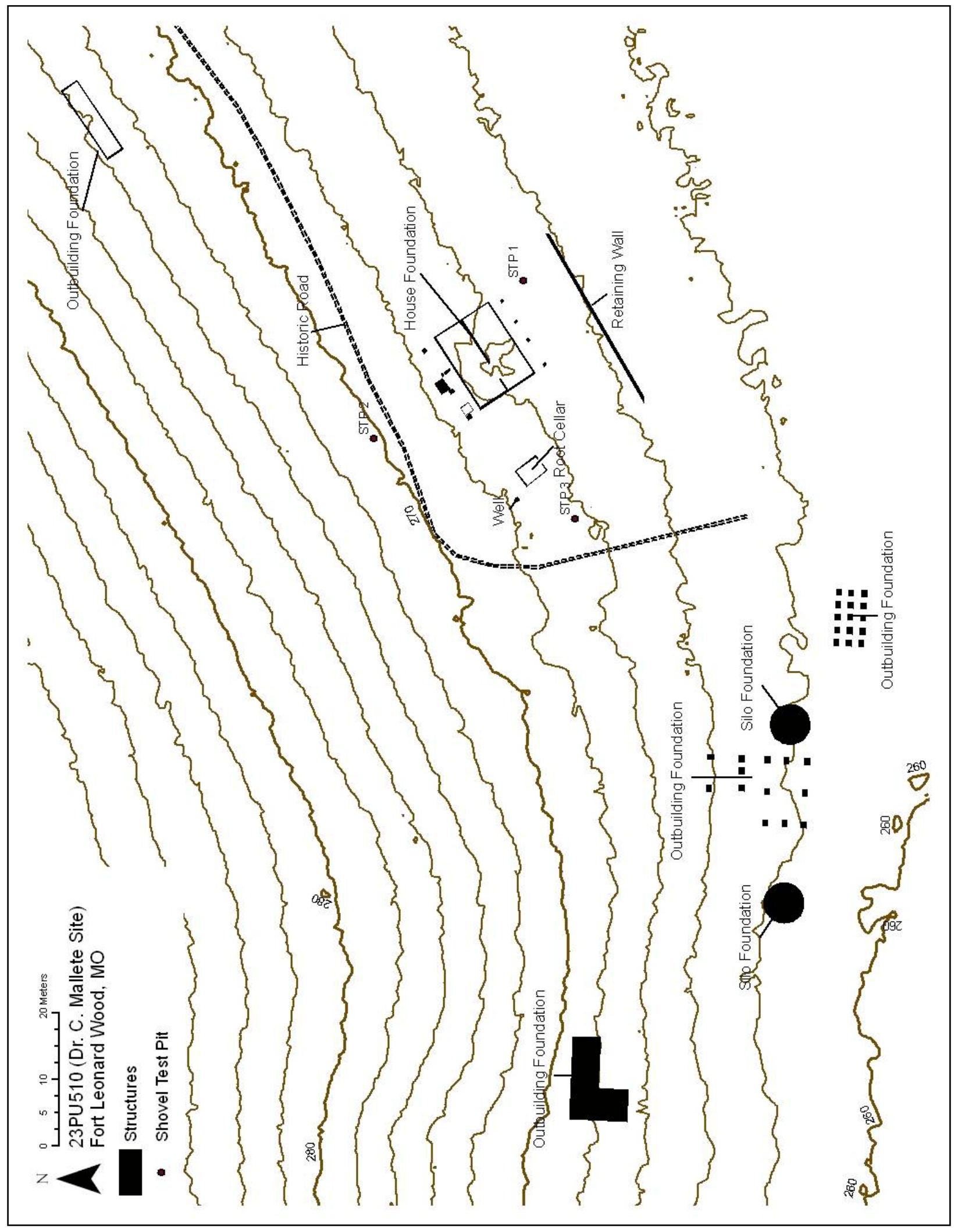

Figure 24. Site map of 23PU510 (ERDC-CERL). 


\subsection{Site description}

Mapping began with using the Trimble GPS. The main house foundation elements, along with two breaks in the wall (one interior doorway, one wall break) were recorded. The pillars along what is interpreted to be the front of the house (the uphill face that opens onto the road) were mapped, as was the set of stairs previously noted. Coordinates were taken for the cistern that lies at the front of the house and connects to the basement through a metal pipe. Several points were taken along the old roadbed where it runs past the house. The outbuilding to the northeast of the house foundation was similarly mapped. A point coordinate was taken for the brick-lined well that stands near the stone-lined root cellar.

Combining the archival research, the previous fieldwork, and the fieldwork undertaken by ERDC-CERL gives a fairly fulsome description of the site and some indication of the range of activities the occupants of the site engaged in.

The core of Site 23PU510 is the house site. The house was a large structure, measuring $13 \times 10 \mathrm{~m}$. The basic footprint size is not particularly notable in comparison to other farmsteads visited during this project. However, this was the only site where the foundation outlined a full-story basement on which the house would have stood. The presence of numerous window and door apertures in the basement foundation suggests it was not merely to support a cabin perched on a hillside, but was an actively used living space. The basement at least was double pen, consisting of front and back rooms. This layout could have been repeated on the upper floor, though that floor could also have been a single pen.

The house probably had a front porch and possibly one on the back of the house. The four columns (two of which are toppled) along the front of the house demarcate a porch footprint, and holes in those columns served as a support for porch beams. The presence of these pillars is evidence of greater architectural elaboration at 23PU510 than at other sites occupied around the same time. The four pillars situated across the rear of the house may have supported a small porch.

To the west of the house, but in close proximity, is a large root cellar and a brick-lined well. The root cellar measures roughly 8 x $8 \mathrm{~m}$ and had a door opening downslope (to the southeast). It was lined with coursed limestone. 
The well remains a sturdy, carefully constructed part of the landscape. Water was observed at the bottom of the well during the field investigations.

The house fronted on the road that was used to connect the site to the main road running past the Dundas School and up to Bloodland. The road's vestiges are clearly visible at the site, and the basic route of the road is visible in LiDAR imagery of Fort Leonard Wood that was collected by the U.S. Army Geospatial Center in Alexandria, Virginia. Northeast of the house core and near to the road stood an outbuilding, possibly a barn or storage facility.

To the southeast of the house stood a series of buildings that were likely associated with agricultural activities at the site. Two silo footings that are girding a structure evidenced by numerous stone piers suggest significant agricultural activities going on at the site. Since the site is located near to and on the floor of the valley leading to Roubidoux Creek, it was likely better farmland than that owned by the neighbors and situated on the high, rocky bluffs. Two other outbuildings may also have been associated with farming at the site.

The site lies in the northeast quarter of the northeast quarter of Section 14, Township 34 North, Range 12 West.

\subsection{Conclusion}

Based on archival research, it seems likely that the site was not actually a significant residence of Dr. and Mrs. Mallette, but was instead the homestead of Mrs. Mallette's parents, Samuel and Elizabeth York. The 1948 real estate map of Fort Leonard Wood, from which the site's name derives, denotes ownership as "Dr. C. Mallette et al.," which indicates ownership was held by more than just Dr. Mallette. The "et al." probably references at least Monta York Mallette, Cyrus's wife, who likely inherited the property from her parents, since both had passed away by the time the 1948 map was made. As stated earlier in this section, Nutt (2012) notes that Dr. and Mrs. Mallette moved to Crocker, Missouri, in 1922. Since that date was well before her parents passed away, it suggests the Mallettes did not live at the site that now bears Dr. Mallete's name.

Regardless of whether it was the homestead of the Mallettes or the Yorks, the site as it now stands is the largest and most elaborate of the farmsteads studied during this project. No other site has a comparably large or com- 
plex foundation (one full story tall, with apertures for windows and doors), piers and stairs suggesting large porches, and numerous outbuildings of significant size. Silo footings like those identified in 1994 are not mentioned at other sites, and few other sites have such large and well-made root cellars attached. In view of these unique characteristics and the overall state of preservation of the site, 23PU510 should be considered potentially eligible for listing on the NRHP. 


\section{Results of Archaeological Investigations at 23PU511 (Zula Hicks Site)}

\subsection{Site history}

The first person to lay legal claim to the land at 23PU511 was Henry Bench, who patented the land in 1859 (Bureau of Land Management 2010). Henry was a son of Daniel Bench, who was the original owner of 23PU510, the Dr. C. Mallette Site. Henry was born in Indiana and died a young man, leaving behind a daughter (Laclede County Genealogical Society 2000).

Neither the 1873 nor the 1906 maps of Pulaski County give any indication of a residence being built at Site 23PU511. By 1930, the land was owned by a C. Hicks (W.W. Hixson \& Co. 1930), most likely Clyde E. Hicks, ${ }^{6}$ husband to Zula Mary Hicks. The couple appears in the 1930 U.S. census for Pulaski County, along with three children: Evan, J oyce, and J ames (U. S. Bureau of the Census 1930).

Zula Mary Hicks, nee Goforth (b. 1898, d. 1948), for whom the site is named, lived at the farmstead with her husband, Ernest Clyde Hicks (b. 1893, d. 1937), who worked as a mechanic in a local garage (State Historical Society of Missouri 2010). The two were married in 1916 and spent most of their adult lives together in Pulaski County, living near her parents and brother and having at least three children together (U. S. Bureau of the Census 1930). Their home appears on the 1944 map of Fort Leonard Wood, though not on the 1937 tourist map of Pulaski County.

Ernest passed away in 1937 from pulmonary tuberculosis in Barnes Hospital in St. Louis at the age of 43. Zula moved to the Kimbrough Rest Home in Springfield, Missouri, around 1948 and stayed there until she passed away from a cerebral hemorrhage in 1958 at the age of 60 (State Historical Society of Missouri 2010). Her name appears on the 1948 real estate map for Fort Leonard Wood, and the claim for the property was in her name.

\footnotetext{
${ }^{6}$ Clyde Ernest Hicks appears as Ernest Clyde Hicks in some documents. Zula Mary Hicks, likewise, appears as Mary Zula Hicks from time to time.
} 


\subsection{Previous fieldwork}

Adams (1997) reported on PSAP fieldwork at 23PU511 that was undertaken in 1996. PSAP archaeologists performed a surface survey of the site to look for features and artifacts and prepared a sketch map. Their survey identified a number of features, but only a few artifacts ("three or four pieces of sheet metal") (Adams 1997). Based on the factors of scarcity of surface artifacts, apparent recent disturbance in the form of foxhole excavation, grading, damage to above-ground features, and the young age of the site, PSAP suggested the site should be considered ineligible for the National Register (Adams 1997).

\subsection{ERDC-CERL fieldwork}

As with the other sites visited during this project, ERDC-CERL archaeologists made a sketch map of the site and complemented it with GPS mapping, conducted a walkover survey, and excavated shovel tests to gauge the degree of integrity of the site's stratigraphy. All fieldwork was conducted on 26 October 2009.

The walkover survey identified most of the features that were identified by Adams and the PSAP crew in 1997, although the fieldstone foundation and concrete wall at the south end of the site (Figure 25) were not seen. Other potential features were identified, though they may be related to recent military training. Few artifacts were visible on the surface due to the heavy groundcover. Only large pieces of sheet metal, likely tin, were observed.

All three shovel tests contained the same soil sequence. A thin $(3-8 \mathrm{~cm})$, very dark brown (10YR2/2) silt with sand and humus inclusions overlay a thicker (10-24cm), very dark grayish brown (10YR3/2) or dark brown (10YR3/3) silt, under which lays a dark yellowish brown (10YR4/4) silty clay subsoil. Shovel tests were dug to a minimum of $8 \mathrm{~cm}$ in the subsoil. All artifacts came from the upper two strata of the shovel tests.

Shovel Test 1 contained a large piece of dressed stone, five brick fragments, one piece of unidentified metal, and 14 nails. The nail fragments were primarily cut nails (10/14), all of which were sevenpenny (7d) nails measuring 2.5-in. long. Wire nails included one 3d, one 7d, and two $20 \mathrm{~d}$ nails, tied together with a piece of iron wire. The presence of wire nails indicates a twentieth-century occupation of the site. Cut nails were widely 
used during the nineteenth century, though they remain in use today and don't necessarily stem from an earlier occupation.

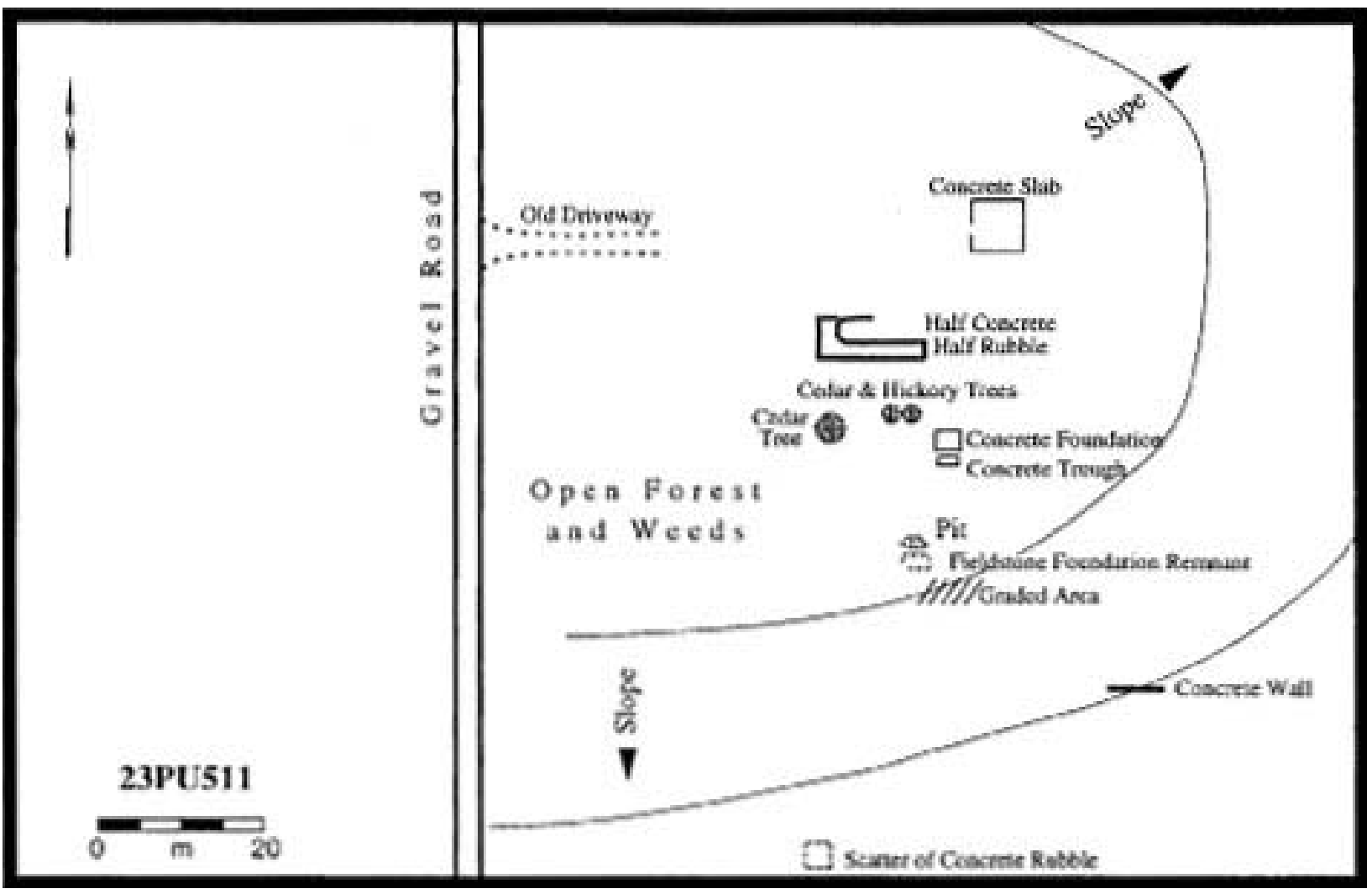

Figure 25. Sketch map of 23PU511 (Adams 1997).

Shovel Test 2 contained a single bottle neck made of colorless glass. It has a continuous thread finish, meant for a twist-off cap, indicating it was made after the 1890s (Lindsey 2011). Mold seams run up to and around the lip, indicating the bottle was made on a fully automatic bottle machine. This observation dates the bottle conclusively after 1904, though likely after 1920 (Miller 1984). The shovel test contained a second piece of colorless vessel glass, though this artifact lacked further diagnostic features. Shovel Test 3 was devoid of artifacts.

The similarity in stratigraphy among the shovel tests suggests that the soils at 23PU511 have not been significantly disturbed for much of the site. The artifacts suggest an early twentieth-century occupation with a possible nineteenth-century component. 


\subsection{Site description}

The site abuts the north-south road that runs through FLW Range 14, passing 23PU284, 23PU509, and skirting the bluff south of 23PU512. The core of the site consists of a poured concrete house foundation, a fallen-in concrete structure that may once have been a root cellar, and a second outbuilding with adjacent concrete trough. A fieldstone foundation to the south of the site core that was observed by the PSAP crew in the 1990s could be another outbuilding. To the north are three shallow depressions that could be the evidences of military training referred to by Adams (1997). The concrete wall and area of concrete rubble identified by PSAP could be associated with the site or could be the result of more recent activities associated with the use of the area as a training range (Figure 26).

The site lies in the southwest quarter of the northwest quarter of Section 13, Township 34 North, Range 12 West.

\subsection{Conclusion}

Based on the documentary and artifactual evidence, it appears that the Zula Hicks Site is an early twentieth-century homestead with little evidence of a nineteenth-century component. The site may have been built by Ernest and Zula Hicks following their marriage in 1916 and was occupied until the creation of Fort Leonard Wood during WW II.

Adams (1997) suggested that the site was not eligible for listing on the National Register of Historic Places, based on the damage to the site, the disturbance caused my military training, and the scant representation of artifacts on the surface. This round of fieldwork identified little that would contradict Adams' finding. 


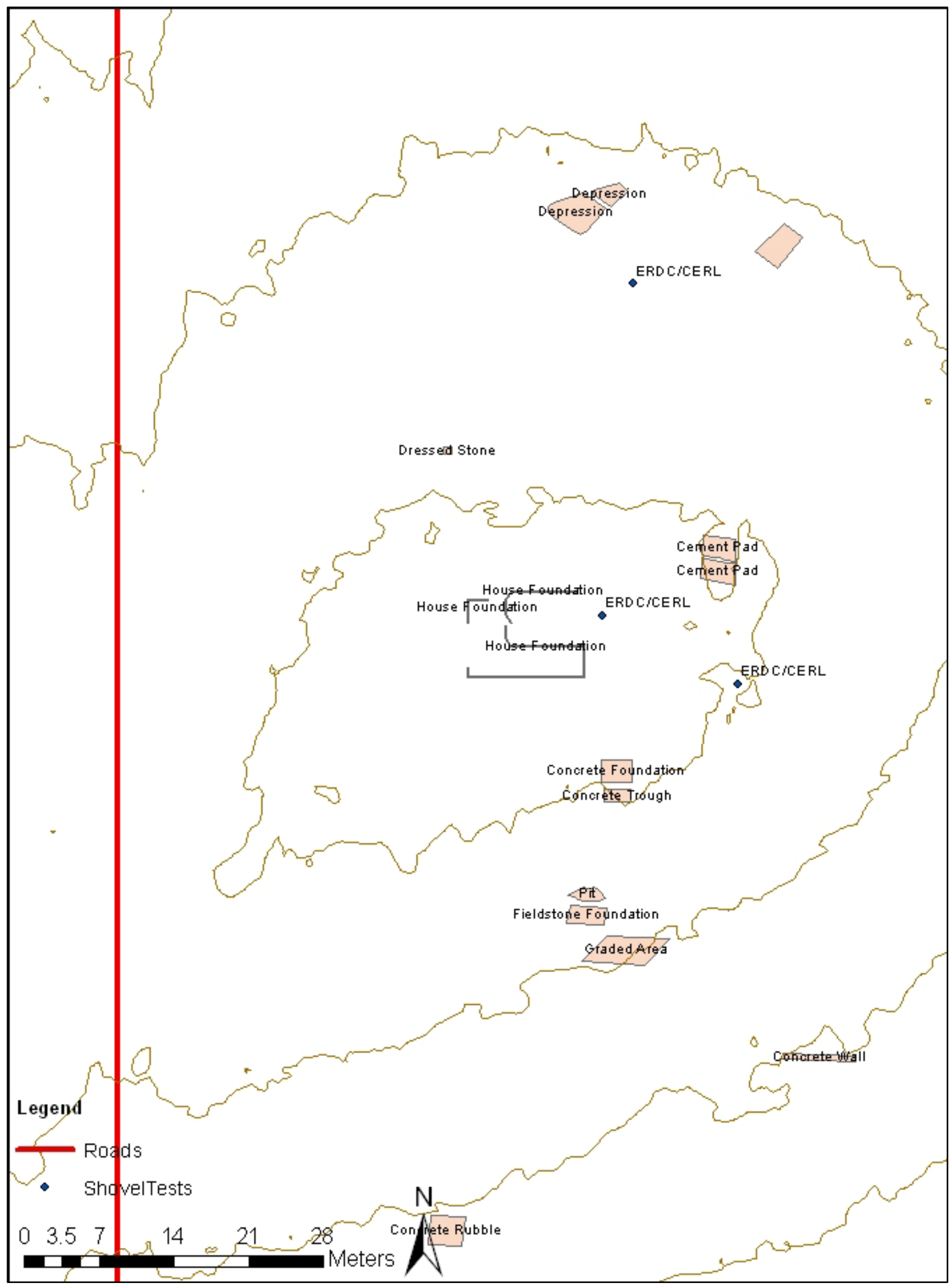

Figure 26. Site map of 23PU511 (ERDC-CERL). 


\section{Results of Archaeological Investigations at 23PU512 (A.L. Hicks Site)}

\subsection{Site history}

The site sits in the area mentioned in previous chapters as "broken country" on the 1873 Shumard map of Pulaski County (Broadhead et al. 1873). The first indication of the land coming under ownership dates to $9 \mathrm{~J} \mathrm{uly}$ 1892, when Henry O. Moyer submitted a patent for 80 acres in Section 13, Township 34 North, Range 12 West (which includes the site location) to the U.S. General Land Office (Bureau of Land Management 2010).

The 1906 map of Pulaski County shows the area of 23PU512 as completely barren. One road stretches towards it, coming south from the Dundas schoolhouse, but there is no evidence of any settlement or improvement of the land. The 1930 plat book for Pulaski County lists the land as owned by a W. McCann (W.W. Hixson \& Co. 1930), though no one by that name appears in the U.S. Census for Pulaski County that year (U.S. Bureau of the Census 1930).

When another map of Pulaski County was made by 1937, a road had been noted that ran just south of 23PU512 and connected Dundas school to Cookeville. Again, there were no apparent improvements to the site of 23PU512, but the 1937 map was made to show tourist attractions, not residences, so it is unlikely that any house present at the site at that time would have been marked on the map.

After the creation of Fort Leonard Wood, there are no representations of 23PU512. The 1944 map of the installation shows neither structure nor the road that used to lead to the site. The 1948 real estate map of the installation shows the parcel where 23PU512 is located as being bought from A.L. Hicks. This map is the source of the name allocated to this site in the ASM database (Adams 1997).

The 1930 U.S. Census lists an Albert L. Hicks, then 25 years of age, as part of the household of his mother, Eliza A. Hicks, of Roubidoux Township, Pulaski County. Eliza Hicks's two grandchildren, Dale L. and Leland D., both 10 years of age, were also members of her household. It is likely that 
Albert L. Hicks is the A.L. Hicks listed on the real estate map, as Eliza Hicks owned a parcel across the road on that same map.

A. L. Hicks may have gone by the names Albert or Lester, as both names appear in census records. The 1910 Census lists Lester Hicks, age 5, as part of the household of Eliza and J ames W. Hicks of Roubidoux Township. Of his parents, Eliza survived her husband J ames by several years. Around 1941 she moved to Burge Hospital in Springfield, Missouri, where she died in 1959 of coronary thrombosis (heart attack) at the age of 91. A.L. Hicks does not appear in the public, national record outside of these few scant instances.

\subsection{Previous fieldwork}

Fort Leonard Wood archaeologists documented 23PU512 in 1994. They identified four site features: a house foundation, well, an outbuilding foundation, and a stone-lined, banked root cellar (Adams 1997). The cellar had a berm running around it, making it an embankment/ hillside cellar under Gage's (2009) classification system.

PSAP archaeologists visited the site in 1996, performing a surface inspection and creating a sketch map (Figure 27). They documented the same four features seen in 1994 (cement house foundation, well, outbuilding foundation, and root cellar ) in the "same condition" as originally described (Adams 1997). Artifacts, none of which were collected, included at least "a bucket, glass soda bottles, food cans, and an enamelware kettle," though no specific counts were provided (Adams 1997). The site was not shovel tested during PSAP fieldwork, nor does it seem to have been shovel tested by Fort Leonard Wood personnel in 1994. 


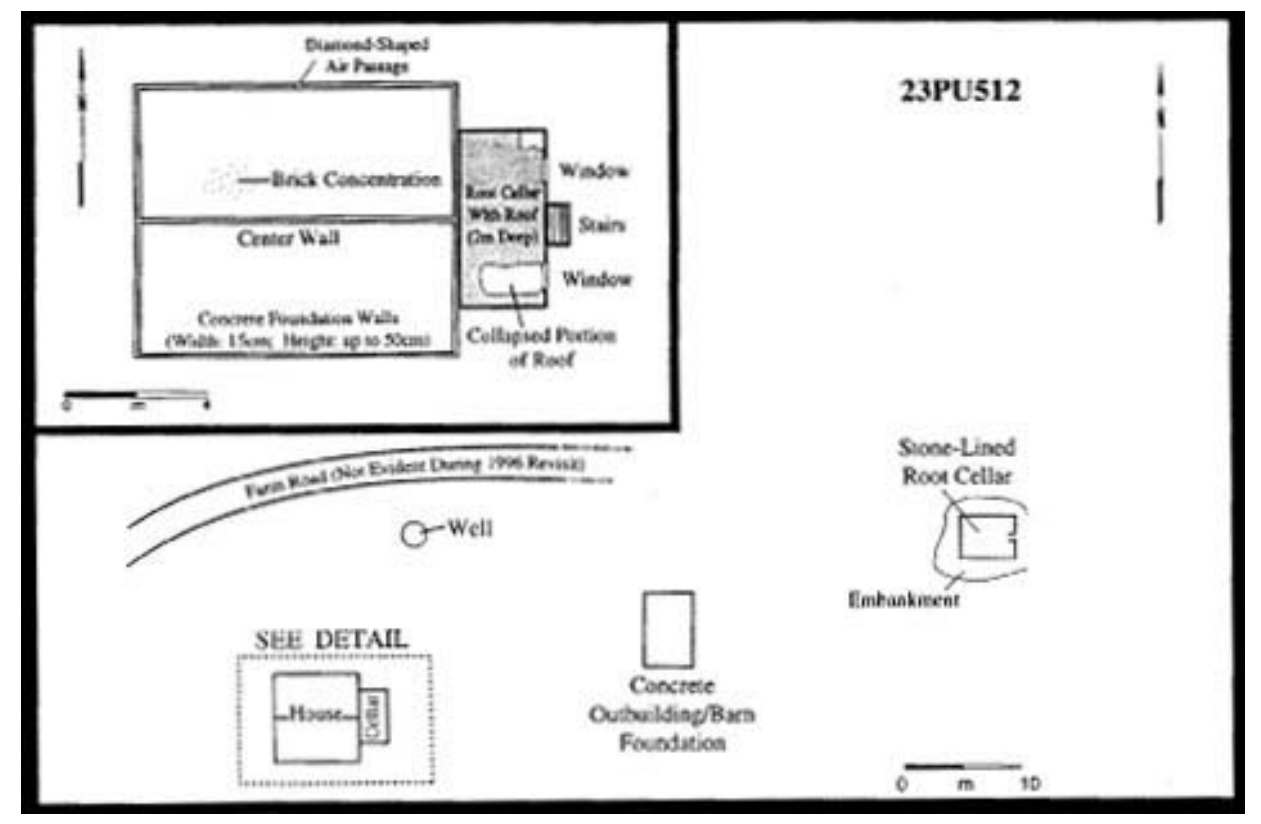

Figure 27. PSAP map of 23PU512 (Adams 1997).

\subsection{ERDC-CERL fieldwork}

Two visits were made to 23PU512, one in October 2009 and the other in J anuary 2010. During the earlier visit, a malfunctioning camera precluded taking site photographs, which were made during the later field visit. All fieldwork except for photography took place during the earlier visit.

As with the other sites, a thorough walkover of the site was conducted to locate previously identified features and to look for others that may have eluded earlier surveys. Shovel tests were dug and a sketch map created of the site. As was the case during the PSAP fieldwork in 1996, no new features associable with the homestead were located.

ERDC-CERL archaeologists dug three shovel tests at the site (Figure 28). All began at the surface with a thin $(2-4 \mathrm{~cm})$ stratum of dark (10YR2/ 4, 10YR2/ 2, 10YR3/2) humic silt. Under this stratum lay $14-17 \mathrm{~cm}$ of dark (10YR4/2, 10YR3/3, 10YR4/4) silty clay/ clay loam, which capped a yellowish brown (10YR5/4) clay subsoil. Artifacts were found in the upper two strata, the subsoil being culturally sterile.

The shovel tests recovered two artifacts. The upper stratum of Shovel Test 2 contained a large piece of sheet metal, which was folded and stamped along one edge. This appears to be tin, perhaps former roofing material for one of the buildings located in the vicinity of the shovel test. It is not con- 
sidered to have much utility as a temporal diagnostic. Shovel Test 1 recovered a carbon rod from a dry cell zinc-carbon battery. Such batteries originated in the late-nineteenth and early-twentieth centuries. The batteries could either be associated with the occupants of the site or subsequent visitation by persons associated with the fort.

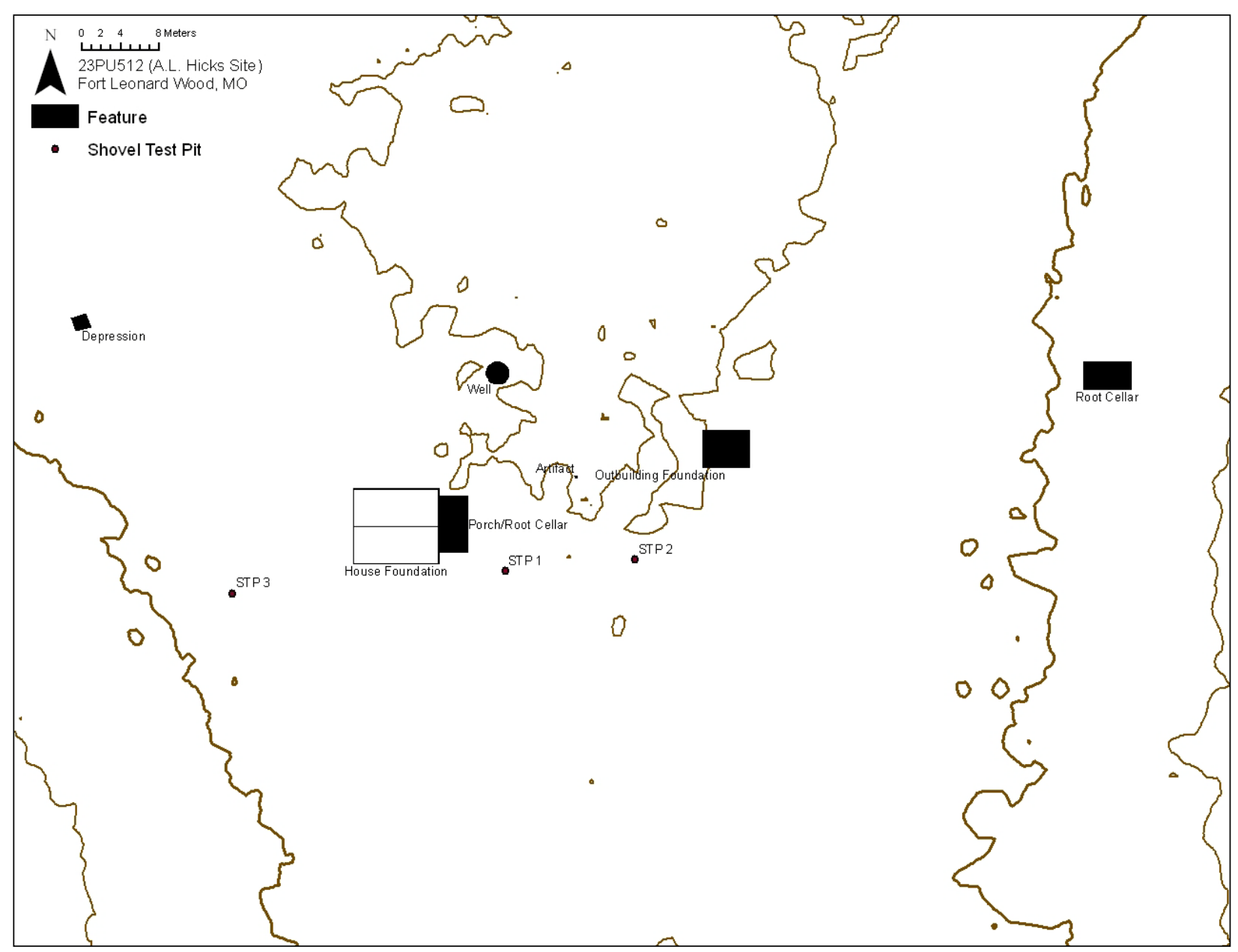

Figure 28. Site map of 23PU512 (ERDC-CERL).

\subsection{Site description}

Site 23PU512 sits atop a ridge overlooking Roubidoux Creek. At one time, a road ran to the site (identified in Figure 27), though that road is now only barely traceable on the landscape. The current installation road runs to the south, along the foot of the bluff on which 23 PU512 stands. Access to the site is easiest by parking at the point where the old road meets the modern installation road, just where it bends to the southeast to track along Roubidoux Creek, and hiking in. Abundant undergrowth on the relict road precludes driving directly to the site. 
The site consists of four features: three foundations and one well. The foundations include a residence with attached root cellar, an outbuilding foundation, and a stone-lined root cellar. The house foundation is made of poured cement, roughly 50-60 cm above ground at its highest point and approximately 15- $20 \mathrm{~cm}$ wide. The foundation was poured in forms made from boards, the impressions of which are easily visible on the foundation as well as on the root cellar. It measures approximately $9 \times 8 \mathrm{~m}(30 \times 26 \mathrm{ft})$ and was likely a double-pen structure given its overall size and the curtain wall running down the center of the foundation (Figure 29).

The roof of the root cellar may have served as a porch as well, as a small set of concrete steps leads up to its top. The root cellar itself is deep, perhaps 6- $7 \mathrm{ft}$ and has both a ventilation hole in its front (facing away from the house foundation) and a large access through its roof, visible in Figure 30. This access was likely covered by a door, under which would have been stairs or a ladder down to the cellar itself. The entryway still has a board fastened to one side, which could have served as an anchor point for a hinge to hold the door.

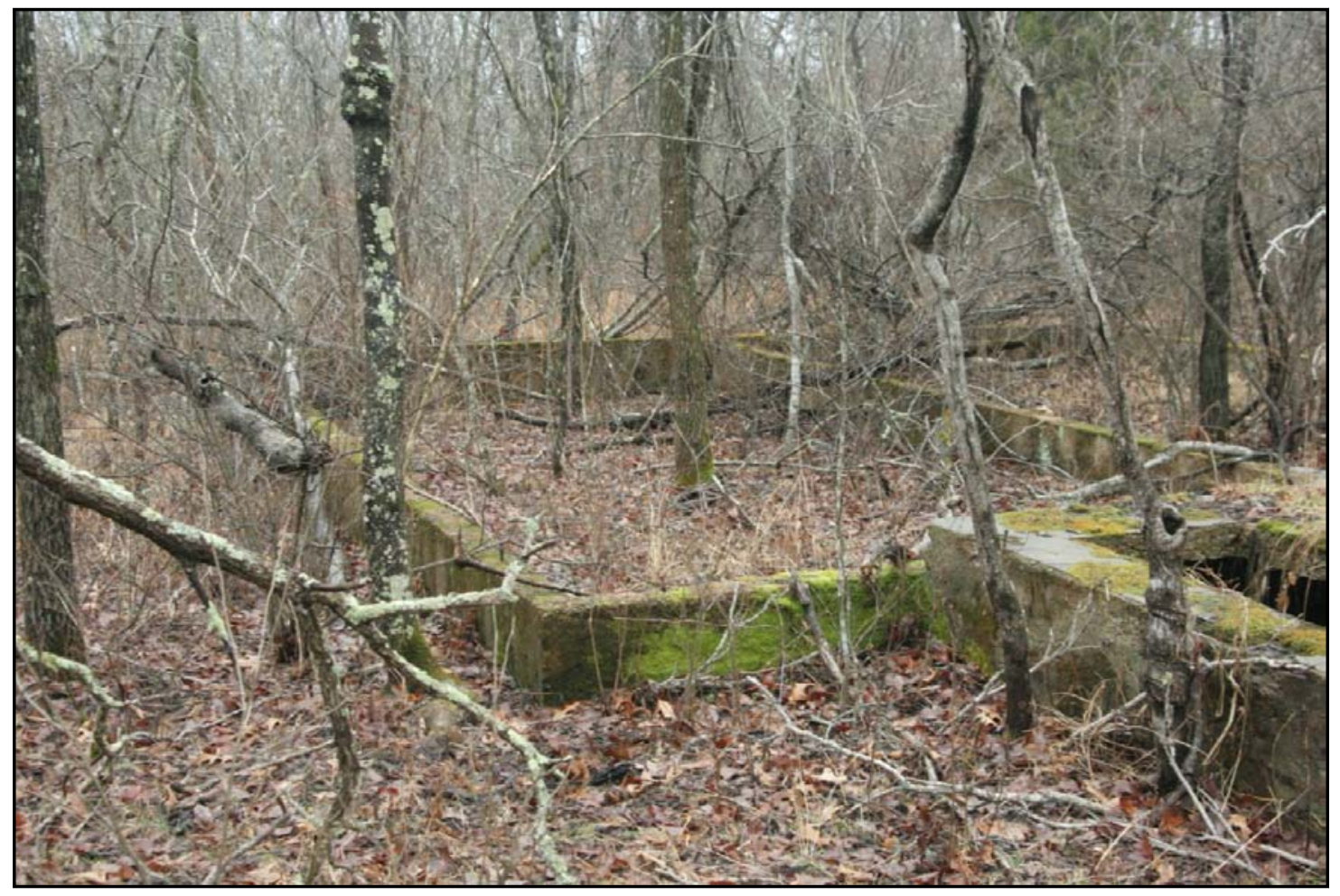

Figure 29. House site, 23PU512 (ERDC-CERL). 


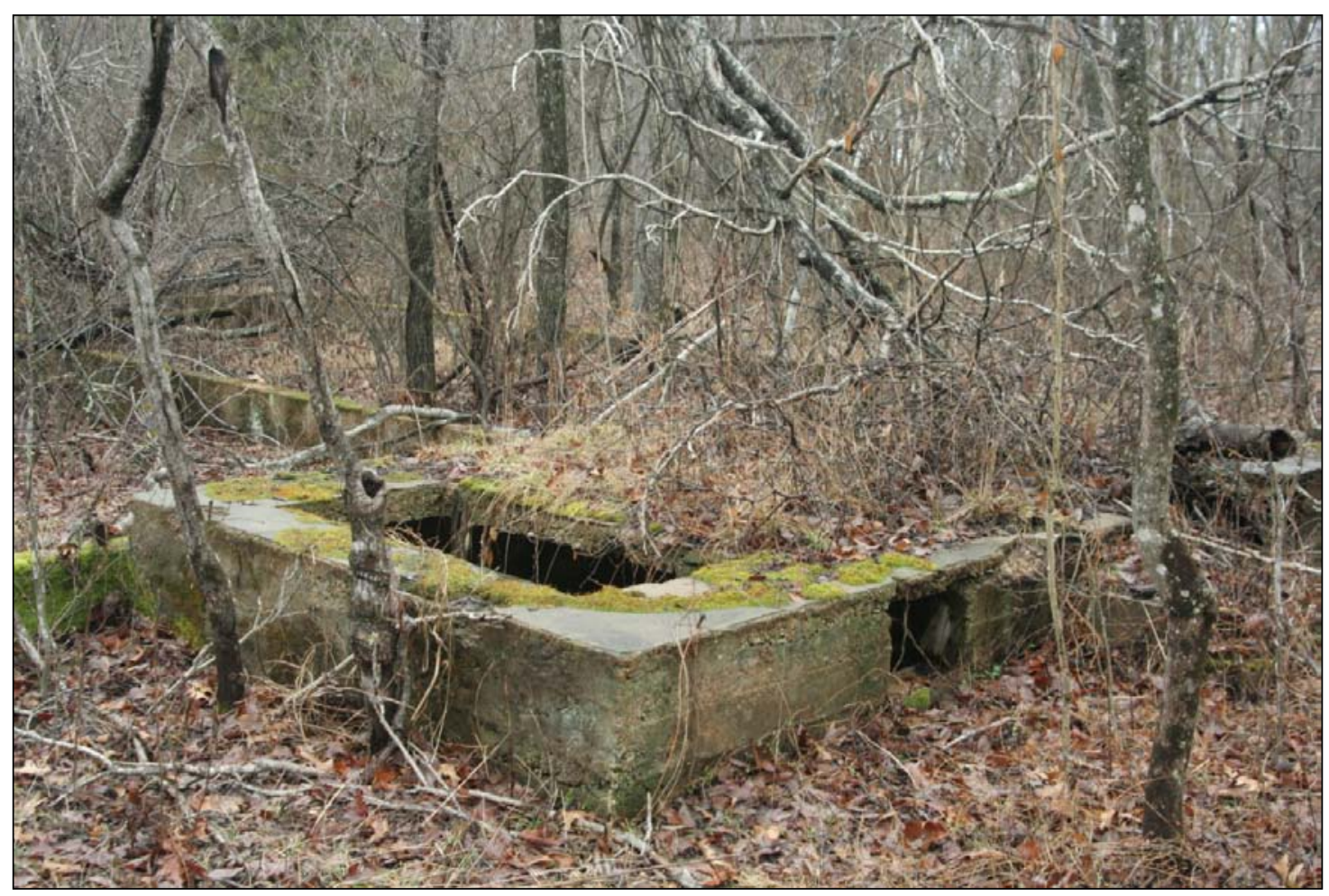

Figure 30. Root cellar, 23PU512 (ERDC-CERL).

\subsection{Conclusion}

Following PSAP's investigations of the site, Adams declined to comment on whether or not 23PU512 should be considered eligible for listing on the NRHP. He did suggest that the site bore further investigation and recommended test unit excavation and detailed site mapping (Adams 1997). That the site was not then written off as ineligible should be seen as evidence that there was some recognition of the possibility that the site would be considered eligible.

While ERDC-CERL's investigations are far from the additional fieldwork Adams suggested, they do support an inferred understanding of the site as potentially eligible for listing. The site appears to be intact and contains the remnants of houses, barns, and root cellars which were part of the adaptation of the inhabitants to life in the Ozark uplands. There appears to be little recent disturbance from military training, and the site is better protected than others seen in this project, given its remoteness from major thoroughfares and the difficulty of the traversing the terrain surrounding it. Though the historical record is very thin on 23PU512, the archaeological potential of the site is much greater. 


\section{Results of Archaeological Investigations at 23PU548 (Lewis Lancaster Site)}

\subsection{Site history}

Marvin Owens of St. Louis County was the first to lay claim to the land on which site 23PU548 is located. He filed a patent on 1 March 1860 with the General Land Office for 320 acres that included the site location (Bureau of Land Management 2010). There is no evidence in U.S. Census records that Marvin Owens ever moved to the land, however, as no men by that name appear in the census records for Pulaski County during the nineteenth century.

In 1873 , the site is shown as part of a plateau covered typically by stands of post oak but largely lacking human habitation (Broadhead et al. 1873). The site location remained vacant in the 1906 map of Pulaski County, though the home of W.S. Williams stood just to the south along the Houston Road (later named Missouri Route 17).

The 1930 plat book for Pulaski County shows W.S. Williams as being the owner of the southwest quarter of the northwest quarter of Section 21, Township 34 North, Range 11 West, where the site is located. The 1930 U.S. Census lists one W.S. Williams in Pulaski County. This was Wesley S. Williams, an elderly farmer who had lived in Pulaski County since at least 1900, as evidenced by the decennial U.S. Census for the years 1900- 1930. Wesley and Malinda Williams raised a family there, one of whom, a son named Walter, would be the claimant on his parents' land in 1948. These are the same Wesley and Malinda Williams from the preceding chapter on 23PU502.

There was no marked residence on the 1937 tourist map of Pulaski County, the only built structures in the vicinity being the Palace schoolhouse and the Palace Civilian Conservation Corps camp, lying to the west and south, respectively. A network of roads ran through the area, some significant, such as the north-south Missouri Route 17, others apparently rather informal. Similarly, the 1944 map of Fort Leonard Wood shows a number of improved and unimproved roads through the area, but no habitations. 
The 1948 real estate map for Fort Leonard Wood shows the land around 23PU548 as part of a 50-acre claim held by Walter E. Williams. Walter E. Williams, as mentioned above, was the son of Wesley and Malinda Williams. The name of the site stems from the claim made to the land just south of the site location. Lewis Lancaster claimed 260 acres in Section 21, but not the portion on which the site now rests.

\subsection{Previous fieldwork}

The site was first reported by Richard Edging and Curt Rankin in April of 1994. They noted it as a nineteenth- to twentieth-century farmstead and drew the site's surrounding boundaries as square, 10 meters per side and oriented to the cardinal directions. They did not make a record of the site's features or note any observed surface artifacts.

McGowan (1996) reported that PSAP was aware of the site during their survey of the Northern Musgrave Hollow Tract on FLW in late 1995. However, there does not appear to have been additional archaeological work performed at that time because the resultant report makes no mention of any being done and gives only cursory reference to the site.

\subsection{Fieldwork}

ERDC-CERL archaeologists visited the site in October 2009, using UTM coordinates provided by Fort Leonard Wood's Department of Public Works to locate it. As with the other sites included in this project, ERDCCERL archaeologists began field investigations by conducting an extensive walkover survey of the site, following by the excavation of two shovel tests. A sketch map was made in tandem with a digital map created with the GPS.

The core of the site consisted of two foundations correlating approximately to the site dimensions recorded by Edging and Rankin. In addition to the two foundations, ERDC-CERL archaeologists noted a large rectilinear depression (see Figure 31). Sea oats were observed to be growing in proximity to the foundations, much like they were at 23PU509.

Two shovel test pits were excavated at the site (see Figure 31 for locations). Both contained heavy concentrations of poorly indurated chert, as is common in Ozark soils. Shovel Test 1 consisted of three strata, a thin humic surface layer (0-1 cmbs, 10YR3/ 1: very dark gray) that was covering 
an artifact-bearing silty clay loam (1- $19 \mathrm{cmbs}, 10 \mathrm{YR} 3 / 2$ : very dark grayish brown), under which lay subsoil, a yellowish brown silty clay (10YR5/4). Shovel Test 2 had, similarly, a thin humic layer (0- $0.5 \mathrm{cmbs}, 10 \mathrm{YR} 3 / 1$ : very dark gray) over a thicker silty clay stratum (0.5- $18 \mathrm{cmbs}, 10 \mathrm{YR} 4 / 3$ : dark brown), under which was clay subsoil (18- 24 cmbs, 7.5YR5/ 6: strong brown).

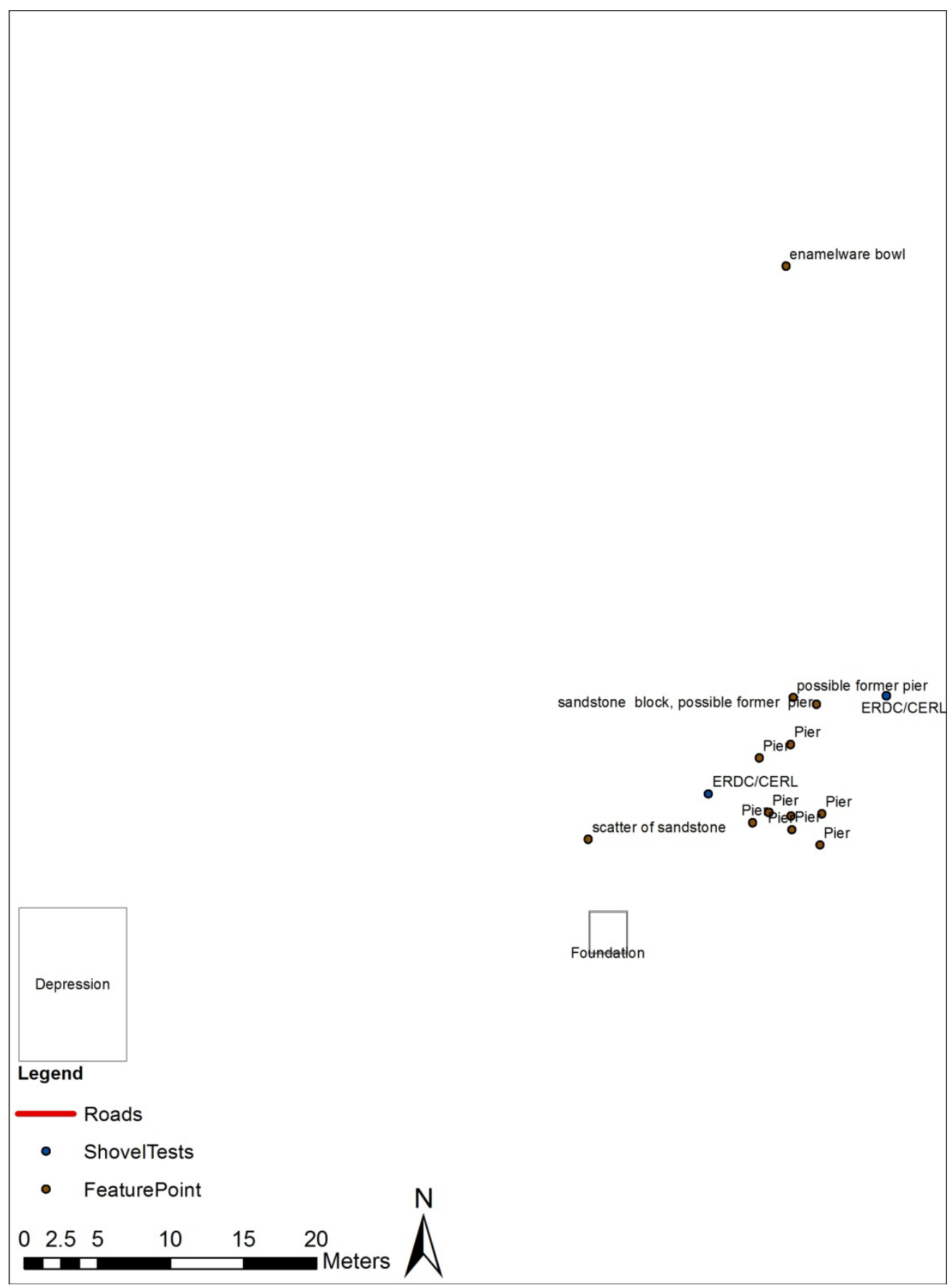

Figure 31: Site map of 23PU548 (ERDC-CERL). 
Shovel tests at 23PU548 yielded seven artifacts (Figure 32). The assemblage includes two pieces of amber bottle glass, four nails, and one white milk glass canning jar lid-liner fragment. All artifacts were found in the second stratum of Shovel Test 1.

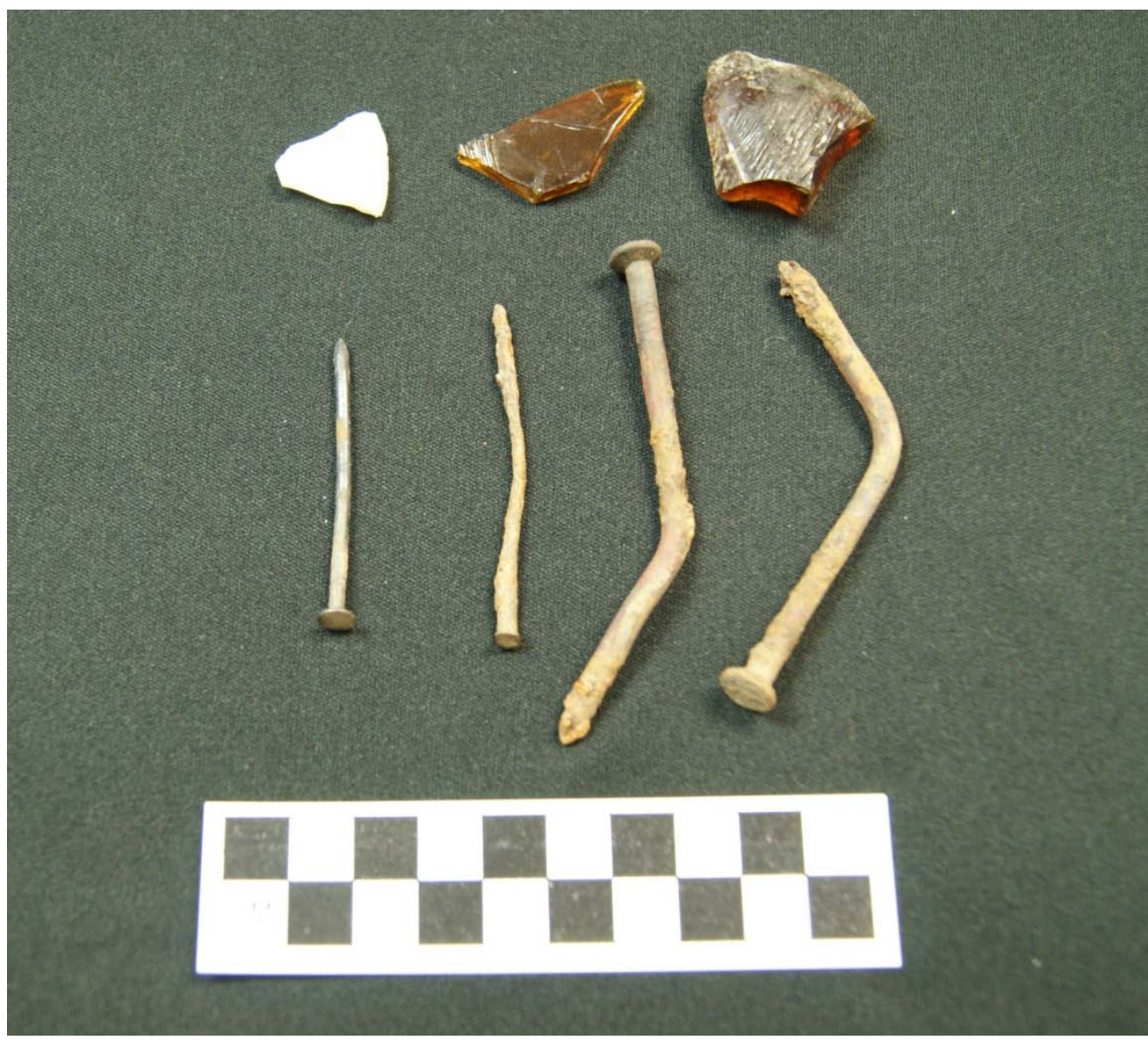

Figure 32: Artifacts from 23PU548 (ERDC-CERL).

Brown or amber glass has been used for bottles and other containers for centuries, though the examples found here are machine-made, meaning they date to the early twentieth century, following the development of automatic bottle-making technology.

Milk glass canning jar lids were first used in the late 1850s to keep the contents of glass canning jars from contacting inside of the lid, which being zinc, would cause the contents to spoil. These jar lids continued in use until the mid-twentieth century, when changes in canningjar technology and a decline in the demand for canning jars in general (spurred by the rise of convenience stores and prepackaged food) rendered them obsolete (Hinson 1996). 
The nails include one sixpenny (6d), one sevenpenny (7d), and two sixteenpenny (16d), which are shown from left to right in Figure 32. One other artifact, an enamelware basin, was observed but not recovered. It lies approximately 30 meters due north of the foundation piers. Enamelware basins such as this were first mass-produced in 1874 and remain in use today.

North of the site runs the vestige of an east-west road that at one point would have connected to Missouri Route 17. The rutting of the roadbed and the arrangement of large trees along its margins make its route still visible, despite the heavy undergrowth that currently dominates the site.

\subsection{Site description}

The core of this farmstead site is the set of foundations, one of poured concrete (measuring approximately $2.5 \times 2.75 \mathrm{~m}$ ), and the other consisting of ten sandstone piers. Given the small size of the poured concrete foundation, it is more likely that this was an outbuilding, one too small for a house, whereas the larger footprint of the piers suggests they were the basis for the house.

Farther west from the foundations is a large rectangular depression surrounded by earthen berms, likely the spoil piles from the excavation of the depression. This depression measures $7.75 \times 10 \mathrm{~m}(25 \times 32 \mathrm{ft})$, and is as much as a full meter deep (measured from the top of the adjacent berm). It lies approximately $30 \mathrm{~m}(100 \mathrm{ft})$ due west from the poured concrete foundations.

The site currently lies in a heavily wooded area near Missouri Route 17, though access was easiest by hiking in from the west after parking near the entrance to a nearby grenade range. A steep-sided drainage cut between Missouri Route 17 and the site makes approaching from the east difficult.

In comparison with the other sites visited during this field project, 23PU548 is a much less elaborate site, having only one small, poured concrete foundation with little elaboration and one pier foundation. The difference in the two foundations could be based on the occupational history of the site, in that poured concrete foundations likely date to later than pier foundations, or the site could have been abandoned before the occupants deemed it worthwhile to replace the pier foundation with a concrete one. The difference could also be a result of the relative wealth of the in- 
habitants, as a poured concrete house foundation would have been more costly than sandstone piers, which could be gathered from the surrounding countryside.

The artifacts recovered from the site suggest a late-nineteenth to earlytwentieth century occupation. None of the artifacts were particularly sensitive chronological indicators, making finer estimations of occupation length impossible in the absence of more archaeological data.

\subsection{Conclusion}

It is difficult to make a suggestion of significance on an archaeological site that has been studied so little. Previous archaeological fieldwork did not advance any suggestion of potential eligibility that could be reviewed in light of new evidence, as was the case with the other sites visited in this project.

It would appear that the site was owned by Walter Williams, son of William and Malinda Williams, whose farmstead is now recorded as 23PU502 (see above). Walter was born around 1905 (U.S. Bureau of the Census 1920), which would suggest that any actual farmstead there would date no earlier than the 1920s. The artifact assemblage associated with the site does not help refine occupational history of the area. Available indications suggest the site was occupied briefly in the early twentieth century, prior to the founding of the fort. Based on this scanty evidence of a brief, recent, and light occupation of the site, it would seem difficult to support an argument for the site's eligibility to the NRHP. 


\section{Application of the Model}

As is clear from the above discussion of the archaeological and architectural research on these farmsteads, Fort Leonard Wood was once home to a close-knit community of families. The physical remains of those families' homes are still much in evidence on the fort's rangelands, 70 years after their abandonment. That community was cherished by its former inhabitants and its loss was keenly felt. Importance and significance are two different categories of value, however, and it is the purpose of this research to apply Enscore et al.'s model for significance determinations to the sites studied in this project. While each have been assessed individually for their eligibility for listing on the NHRP, the model used here discusses them in aggregate.

Enscore et al (2005) developed the approach to significance modeling. This approach relies on the information gathered to answer the Site Inventory Form that is completed for each site. Used in tandem with the Eligibility Prescreening Form, the Site Inventory Form guides cultural resources specialists to collect both historical and cultural data necessary to make significance determinations rapidly and accurately.

The model used by Enscore et al. $(2005,5)$ assumes that the historic sites at Fort Leonard Wood "were similar in terms of size, materials, construction, and layout." Having made that assumption, it seeks to identify the most typical, best examples of historic properties, which can then be preserved, allowing less valuable resources to be removed from the cultural resources inventory.

The sites used in this project were flagged as potentially eligible by the Eligibility Prescreening Form, and the fieldwork described above constituted the fieldwork phase of the testing process described in Enscore et al. (2005, 10). In spite of previous significance assessments, the sites used in this research were believed to be potentially significant before the fieldwork phase.

Most of the sites used in this project had been assessed in terms of significance by earlier researchers. In those earlier assessments, Site 23PU284 (Dundas School) and 23PU511 (Zula Hicks Site) were considered ineligi- 
ble, while 23PU502 (Root Cellar), 23PU508, and 23PU510 (Dr. C. Mallette Site) were suggested as being eligible. No determinations were offered in the cases of 23PU509 (Bryum L. Christeson Site) and 23PU548 (Lewis Lancaster Site).

Based on the cumulative fieldwork conducted on these sites, 23PU502, 23PU508, 23PU510, and 23PU512 could be considered eligible for listing on the NRHP under Criterion D (potential for recovery of future scientific data). The 23PU284 site is likely ineligible given its extensive disturbance. Also, 23PU509 is likely ineligible, but this ineligibility is due more to the lack of evidence for significant artifactual deposits at the site and some disturbance to the foundation wall. In the case of 23PU548, a situation where there has been very little total fieldwork, making a recommendation of eligibility is a tenuous task at best. The site could contain a temporally discrete, early-twentieth century assemblage of artifacts, but this has not been demonstrated. At our present level of knowledge, it may be considered not eligible for listing, as there is no strong indication that the site will yield important information relative to the NRHP listing criteria. Finally, 23PU511 was seen as ineligible by previous field researchers, an interpretation that ERDC-CERL archaeologists did not find evidence to counter.

Among the four sites suggested as eligible, the model developed by Enscore et al. (2005) suggests identifying the best-preserved, most "typical" sites and flagging them for preservation at the expense of the others. Of these four, then, 23PU510 and 23PU512 should be seen as the most valuable.

The Dr. C. Mallette site, 23PU510, is by far the most elaborate of the farmsteads visited during this project. Its full-story cellar, which is in better condition than other cement curtain wall cellars seen in this project, was unique among the sites visited. The documented presence of additional outbuildings, including storehouses and silo footings, suggests the possibility for recovering substantial quantities of data about the farming practices of the region in the early twentieth century.

The 23PU512 site is similarly well-preserved, has numerous outbuildings, and has a stone-lined root cellar like 23PU502 and 23PU510. Markedly less elaborate than 23PU510, it may mark a socioeconomic class difference between its former inhabitants and the York family at 23PU510. It could 
also reflect a different adaptation to the landscape, as 23PU512 sits atop a bluff, while 23PU510 is situated on the lowlands near Roubidoux Creek.

Taken together, these sites contain many of the different kinds of architecture seen in the course of this project including stone-lined root cellars, brick-lined wells, foundations for houses and outbuildings, and vestiges of roads and paths connecting the sites to the wider world. Preserved for future study, these sites offer the best opportunities for learning about local adaptations to living in the rough Ozark uplands.

Suggesting that 23PU510 and 23PU512 be preserved entails simultaneously suggesting that 23PU502 and 23PU508 be let go. There are reasons for selecting against each of these latter sites. The 23PU502 site, while welldocumented and containing an excellent example of a stone-lined root cellar, does not offer architectural or archaeological data that is not recoverable elsewhere among these sites. Because the architectural research for this project found little to suggest this was an atypical form for a root cellar, there is little more to be gained from retaining it in preference to 23PU510 or 23PU512, each of which has such a root cellar in addition to other unique architectural features.

Site 23PU508 has the potential to yield additional data on the history and culture of the Ozark uplands, but it has clearly had greater recent visitation (witnessed in the form of scatters of modern trash across the site), which is a disturbance to the site. Additionally, the evidence for earthmoving at the northeast end of the site suggests some potential damage to site features, which diminishes its integrity, though not enough to render it ineligible. Being closer to an active training road than either of the two sites suggested for preservation makes 23PU508 more threatened to be further damaged in the future.

Given the emphasis on identifying the most typical and best preserved sites for preservation, as dictated by the model used in this project, the research done for this task would hold that 23PU510 and 23PU512 are the best candidates for preservation. 


\section{Discussion of the Model}

Before concluding this project, it is necessary to offer some comments on the effectiveness of the model developed by Enscore et al. (2005) to help refine the model for future, hopefully wider, use. While the approach and undergirding principles represent the possibility of significant cost savings to the Army while continuing to fulfill its mandates toward cultural resources, there are a few issues that arose during the course of this project that should be considered in future by researchers interested in advancing this work.

This is not the first time that archaeologists find themselves confronted by large numbers of recent, primarily rural, sites for which they must develop methods for determining significance, eligibility, or relevance. The techniques provided by other instances of this can serve as comparative case studies against which the landscape model used at Fort Leonard Wood may be held.

For instance, Wilson (1990) confronted this same issue of scale in dealing with numerous farmsteads around Surry, New Hampshire, during his work for the New England Division, U.S. Army Corps of Engineers. His chosen approach to separating wheat from chaff was to look at the known history associated with each site and, based upon the brevity of occupation and the level of re-modeling occurring at each site (less being considered better), choose to save only a small number of sites which he deemed most likely to yield large amounts of archaeological data. His argument was based on Criterion D for inclusion in the National Register of Historic Places.

Similarly, in the late 1990s, the Atomic Energy Commission had to sample 1,002 historic farmsteads on the Aiken Plateau in South Carolina (Cabak, et al. 1999). Located on land claimed by the Atomic Energy Commission in 1951, these sites were shovel tested and mapped in much the same fashion as were the sites at Fort Leonard Wood for this project. Though excavated by the same company as part of the same project, the Aiken Plateau sites do not appear to have been considered jointly from a managerial standpoint, as the reports for the project broke the area up into distinct tracts and reported on in piecemeal fashion. They were considered jointly in ac- 
ademic publications, where Cabak et al. (1999) considered them in aggregation to study rural modernization in the wake of the Second World War, finding that the area did not share in the rapid changes in housing types being produced elsewhere in the United States at that time.

Though Wilson (1990), unlike the researchers studying the Aiken Plateau, did make an attempt to apply a significance model to a large number of farmsteads, it should be noted that his model was heavily criticized by Leone and Potter (1992). The critics charged that Wilson's model was too heavily based in logical positivism, causing it to focus on questions relevant only to archaeology, and not society as a whole. Also, it employed an essentialist understanding of significance, wherein significance is something inherent to the site, whereas Leone and Potter see significance as something ascribed by the investigators and society at large.

This last critique is of interest to this project, as it underscores the difficulty of making significance and eligibility determinations. While the Site Inventory Form was useful to the project, too heavy a reliance on the form and the answers to its questions can divert the archaeologist and cultural resources manager from an appropriate attention to the historical content and relevance of the site to answering questions about American history. Too great an attention to the details of a site runs the risk of causing inattention to wider issues that bear importantly upon it.

\subsection{Use of the Site Inventory Form}

In general, the Site Inventory Form was a very useful tool for fleshing out the documentation of each site. It asks questions of the field archaeologist that might not otherwise have been noted, and provides space for detailing historical, architectural, landscape, and artifactual data, all important in properly characterizing the site as has been done here. That being stated, there are a few alterations to the Site Inventory Form that would improve its utility, both on conceptual grounds and in view of the exigencies of doing fieldwork.

One alteration to the Site Inventory Form that would be advantageous for field personnel would be splitting the form into two or three smaller forms, one for documentary data, one for field data, and a third for artifactual data. These could and perhaps should be completed at different stages of the research process. Some of the data fields need to be answered in the field, but others, such as artifactual data and questions of the typi- 
cality of the architecture, can be answered more readily after the project has been completed and the artifacts properly curated and analyzed.

Based on purely practical considerations, putting field data on a separate form would be advantageous in that the conditions of fieldwork often have a remarkably deleterious effect on the physical integrity of forms carried in the field, and isolating the field data onto separate forms would reduce the threat to the other forms of documentation that are not needed in the field. For instance, the weather during virtually every day of fieldwork associated with this project was exceedingly rainy, and forms had to be filled out in the hotel room at the close of the day, as exposing the paper itself to the elements would have caused it to disintegrate in a few minutes.

One alternative would be to create a digital form for the field data (or all data categories) that could be loaded onto a weatherproof digital recording device, such as the GPS used in this project, that would allow for speedy recordation of field observations in a format more water-resistant than paper.

Conceptually, the Site Inventory Form could bear two additions, enhanced flow direction and greater specificity. For flow direction, instructions on which questions still apply should a site not be a farmstead, as was the case for 23PU284 (Dundas School), would be helpful in letting the archaeologist know what questions the model developers did not expect to be applied for such cases. Several of the subsequent questions assume that the site is a farmstead, and therefore do not apply in cases where the site served some other function.

Also, there is not a clear distinction between farmstead and homestead. Ernest Hicks, who lived with his wife, Zula, at 23PU511, was primarily not a farmer but a mechanic. There is no historical information that would suggest he farmed the land surrounding his house. Does his occupation make the site of his former abode a homestead rather than a farmstead, and should we consider that in the context when attempting to model significance for these sites?

Greater specificity is called for in the artifact section. Ceramics are divided by type, but not by decoration style (transfer-printing, hand painting, etc.) which would be useful temporal and status indicators. Container glass is broken into beverage bottles, food containers, and medicine bottles, which 
are useful functional categories but do little to help date the site. Archaeologists much more frequently use technological indicators, such as mold seams, pontil marks, decolorants, etc., to establish the approximate age of a site, none of which are reflected in the Site Inventory Form. The same could be said for bricks (handmade versus machine-made). Finally, there are no categories for personal effects, miscellaneous other categories, or military hardware stemming from recent disturbances to the site that would be important to document and could aid in making significance determinations.

Additional specificity would be useful in the form's Archival Sources for Property section. Under "Maps," the check box for historic maps could be expanded to encompass specific maps so that others reviewing the documents could see what maps had been consulted. The same holds for aerial photographs. There are a finite number of these, most or all of which are on file with Fort Leonard Wood's DPW, and could be easily compiled into a more specific list. Finally, there are different check boxes for "historic maps" and "county maps," though it is unclear what the distinction between the two is.

\subsection{Historical context}

Finally, the model is based on Smith's Made in the Timber, a historical context written for the installation that lays out temporal categories to aid in classifying sites. While the book has numerous strengths, its one key weakness is an inattention paid to three lines of division in society that are commonplace in current historical archaeology. Race, class, and gender distinctions receive little focus, which shapes how we understand Fort Leonard Wood's past. Clearly, Pulaski County has never been an all-white society, though there is little recognition of the presence of AfricanAmericans (free or enslaved) in the region early in its history, though census records clearly indicate that there were.

Further, the Dr. C. Mallette site (23PU510) was quite an elaborate farmstead, one more favorably suited to agriculture than the upland sites of 23PU512 or 23PU511. Could this be evidence of economic stratification in the rural South? If so, these sites offer a valuable opportunity to study the topic archaeologically. However, Made in the Timber gives this and other areas of research common to historical archaeology in general, and farmstead archaeology in particular, very short shrift. 


\subsection{Conclusion}

These suggestions aside, the model as presented offers a useful, valuable tool for grappling with the problem of assessing the eligibility of these sites for listing on the NRHP. With some tweaking, future applications of the model at Fort Leonard Wood and elsewhere will be a benefit to the Army by allowing it to fulfill its duties to American heritage quickly and efficiently. It could also be a boon to cultural resources management, as being able to quickly identify which sites need to be protected and which can be let go will ensure that those from which we can learn most can be identified and preserved quickly. 


\section{Conclusion}

Section 110 of the National Historic Preservation Act of 1966, as amended, requires federal agencies to "establish a preservation program for the identification, evaluation, nomination to the National Register, and protection of historic properties." The project reported here is part of Fort Leonard Wood's ongoing and consistent effort to fulfill its mandates and to be a good neighbor to the communities surrounding the installation that have deep historical, cultural, and familial ties to the sites now located inside the fort.

While the model developed by Enscore et al. (2005) does need some adjustments to enhance its effectiveness as a cultural resources tool, the approach it advocates offers a very useful resource for the installation. Faced with literally hundreds of historical archaeological sites to manage, the installation needs tools such as this model to identify those historic properties that are most valuable and most in need of preservation.

Tools such as the model used in this report offer savings (primarily in time) to the Army. Faced with the massive challenge of managing hundreds of sites, many of which have not been fully assessed regarding their eligibility for listing on the NRHP, the cultural resources managers at Fort Leonard Wood need ways to rapidly identify important sites and, equally important, sites that are clearly ineligible for listing. This assessment allows attention and resources to be focused on those sites that will, through study, most benefit our understanding of the Ozark past.

The effects of this approach have ramifications outside the world of cultural resources management. Being able to separate the wheat from the chaff of historic sites has important benefits to military training. Knowing which sites stand no chance of being eligible for listing on the National Register removes them from consideration when planning training exercises. This increases the size of a rangeland's landmass that is open to training as well as defragmenting it.

The approach developed by Enscore et al. (2005) proved effective at identifying sites that may or may not have been eligible for listing by using the Eligibility Prescreening Form. Then, subsequent fieldwork driven by the 
Site Inventory Form, supplemented by basic historical research, separated those sites that were worthy of further investigation from those that were not. Though the historical context driving the model and the forms associated with the project need some adjustment, they constitute a very valuable cultural resources tool with wide applicability. Given that there are many installations around the country that were formed in similar circumstances to Fort Leonard Wood, the successful implementation of this approach there could lead to its adoption around the country. This would allow the Army to preserve American heritage very economically while enhancing its ability to train and prepare to complete its missions. 


\section{References}

Adams, B. 1997. Phase I Archaeological Survey of 3,000 Acres at Fort Leonard Wood, Pulaski County, Missouri. Public Service Archaeology Program, Department of Anthropology, University of Illinois. Submitted to U.S. Army Construction Engineering Research Laboratory. Copies available from DACA88-94-D-0008.

. 2003. Cultural Resources Survey of 646.15 Hectares in the East Musgrave Hollow Area and Falls Hollow Area Tracts at Fort Leonard Wood, Pulaski County, Missouri. Public Service Archaeology Program, Department of Anthropology, University of Illinois. Submitted to U.S. Army Construction Engineering Research Laboratory. Copies available from DACA42-00-0011.

Ahler, S. R., D. Naglich, B. W. Styles, M. B. Schroeder and E. C. Brand. 2009. National Register Eligibility Assessment of Two Prehistoric Sites (23PU223 and 23PU264) and Six Historic Sites (23PU243, 23PU278, 23PU397, 23PU398, 23PU449, and 23PU502) at Fort Leonard Wood, Missouri. Illinois State Museum Society. Submitted to U.S. Army Engineer Research and Development Center, Construction Engineering Research Laboratory. Copies available from W9132T-05-D-003.

Alwood, W. B. 1895. A New Plan for the Construction of a Storage Cellar. Bulletin No. 58. Virginia Agricultural and Mechanical College, Blacksburg.

Bolton, S. C. 1998. Arkansas, 1800-1860: Remote \& Restless. University of Arkansas Press, Fayetteville.

Broadhead, G. C., F. B. Meek and B. F. Shumard. 1873. Reports on the Geological Survey of the State of Missouri, 1855-1871. Regan \& Carter, J efferson City, Missouri.

Bureau of Land Management. 2010. General Land Office Records.

Busch, J . 1981. An Introduction to the Tin Can. Historical Archaeology 15(1):95-104.

Cabak, M. A., M. D. Groover and M. M. Inkrot. 1999. Rural Modernization During the Recent Past: Farmstead Archaeology in the Aiken Plateau. Historical Archaeology 33(4):19-43.

Edging, R., L. Whalley, A. Smith, S. Smith, D. Mather, M. Chawla and S. K. Loechl. 2003. Fort Leonard Wood Integrated Cultural Resources Management Plan. Special Report. U.S.ACE/ ERDC-CERL, Champaign, Illinois.

Enscore, S., S. K. Loechl, M. W. Tooker and S. L. Nutt. 2005. A Landscape Approach to Determining Significance of 19th and 20th Century Farmsteads and Rural Communities, Fort Leonard Wood, Missouri. U.S. Army Engineer Research and Development Center, Construction Engineering Research Laboratory. Submitted to Natural Resources Directorate of Public Works, Fort Leonard Wood. Copies available from MIPR2ACER006.

Fike, R. E. 1987. The Bottle Book: A Comprehensive Guide to Historic, Embossed Medicine Bottles. The Blackburn Press, Caldwell, NewJ ersey. 
Gage, J . E. 2009. Root Cellars in Ameria: Their History, Design and Construction 16091920. Powwow River Books, Amesbury, MA.

Hervert, J . and E. Allen. 1980. Midwestern Vernacular: Farm Structures in Kane County, Illinois. Kane County Urban Development, Geneva, IL.

Hinson, D. 1996. "A Primer on Fruit J ars." Originally a feature article from Bottles \& Extras. Available at http:// www.av.qnet.com/ glassman/info/ b\&e/ primer.htm

Higgins, Minnie A. 1924. "Map of Pulaski County, Mo." In the files of Fort Leonard Wood and ERDC-CERL.

J ones, O. and C. Sullivan. 1989. The Parks Canada Glass Glossary for the Description of Containers, Tableware, Flat Glass, and Closures. Minister of Supply and Services Canada, Ottawa, Ontario.

Kreisa, P. P. and B. Adams. 1999. Phase I Survey of 3,511 Acres at Fort Leonard Wood, Pulaski County, Missouri. Public Service Archaeology Program, Department of Anthropology, University of Illinois. Submitted to U.S. Army Construction Engineering Research Laboratory. Copies available from DACA88-97-D-0018.

Kreisa, P. P., J . M. McDowell, K. P. McGowan, G. R. Walz, B. Adams and D. J . Halpin. 1996. Phase I Survey of 3,500 Acres at Fort Leonard Wood, Pulaski Co., Missouri. Public Service Archaeology Program, Department of Anthropology, University of Illinois. Submitted to U.S. Army Construction Engineering Research Laboratory. Copies available from DACA88-94-D-0008.

Laclede County Genealogical Society. 2000. Laclede County, Missouri: History and Families. Turner Publishing Company, Paducah, Kentucky.

Leone, M. P. and P. B. Potter, Jr. 1992. Legitimation and the Classification of Archaeological Sites. American Antiquity 57(1):137-145.

Lindsey, B. 2011. Historic Glass Bottle Identification \& Information Website.

Linklater, A. 2002. Measuring America: How an Untamed Wilderness Shaped the United States and Fulfilled the Promise of Democracy. Walter \& Co., New York.

MoGowan, K. P., 1996. Phase I Survey of Four Thousand Acres at Fort Leonard Wood, Pulaski Co., Missouri. Public Service Archaeology Program, Department of Anthropology, University of Illinois. Submitted to U.S. Army Construction Engineering Research Laboratories. Copies available from DACA88-94-D-0008.

Miller, G. L. 1984. Machine-Made Glass Containers and the End of Production for Mouth-Blown Bottles. Historical Archaeology 18(2):83-96.

1991. A Revised Set of CC Index Values for Classification and Economic Scaling of English Ceramics from 1787 to 1880. Historical Archaeology 25(1):1-25.

Neumann, T. W., and R. M. Sanford. 2001a. Cultural Resources Archaeology: An Introduction. Alta Mira Press, Lanham, NY. . 2001b. Practicing Archaeology: An Introduction to Cultural Resources Archaeology. Alta Mira Press, Walnut Creek, CA. 
Newman, T. S. 1970. A Dating Key for Post-Eighteenth Century Bottles. Historical Archaeology 4(1):70-75.

Niebrugge, P. W. 2009. Oral interview, edited by E. Hartman.

Nutt, S. L. 2012. Bloodland: A Community Lost But Not Forgotten. Old Settlers Gazette:30-41.

Pollock, D. 1978. Cellars: A Store of Produce. Bittersweet 5(3):46-52.

Pulaski County Historical Society. 2009. Pictures, Stories, History of Pulaski County Rural Schools. Pulaski County Historical Society, Waynesville, Missouri.

Rafferty, M. D. 1980. The Ozarks: Land and Life. University of Oklahoma Press, Norman.

Reierson, A. D. 2010a. The J ohnson Family Home Page: Information about Charles Christopher Woody.

. 2010b. The J ohnson Family Home Page: Information about Mary Ethel Bailey.

Smith, S. D. 2003. Made in the Timber: A Settlement History of the Fort Leonard Wood Region. ERDC-CERL Special Report 03-5. U.S. Army Maneuver Support Center, Fort Leonard Wood, Missouri.

Social Security Administration. 2010. Social Security Death Index, Master File.

Secretary of State, Missouri. 2010. Missouri Digital Heritage: Death Records Certificates.

Toulouse, J . H. 1971. Bottle Makers and Their Marks. Blackburn Press, Caldwell, New Jersey.

U.S. Bureau of the Census. 1840, Sixth Census of the United States. U.S. Department of Commerce, Washington, DC. . 1850. Seventh Census of the United States: Schedule I. U.S. Department of Commerce, Washington, DC. . 1860. Eighth Census of the United States: Schedule I. U.S. Department of Commerce, Washington, DC.

. 1870. Ninth Census of the United States: Schedule 1. U.S. Department of Commerce, Washington, DC.

. 1900. Twelfth Census of the United States: Schedule No. 1 - Population. U.S. Department of Commerce, Washington, DC

. 1910. Thirteenth Census of the United States: 1910 - Population. U.S. Department of Commerce, Washington, DC. . 1920. Fourteenth Census of the United States: 1920 - Population. U.S. Department of Commerce, Washington, DC.

. 1930. Fifteenth Census of the United States: 1930 - Population Schedule. U.S. Department of Commerce, Washington, DC. 
W.W. Hixson \& Co. 1930. Plat Book of Pulaski County, Missouri. W.W. Hixson \& Co., Rockford, Illinois.

Williams, G. 2009. Oral Interview, edited by E. Hartman.

Wilson, J . S. 1990. "We've Got Thousands of These! What Makes an Historic Farmstead Significant?" Historical Archaeology 24(2):23-33. 


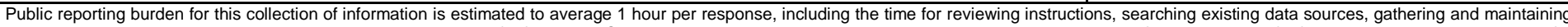

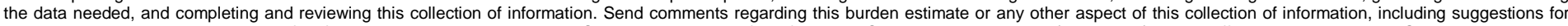

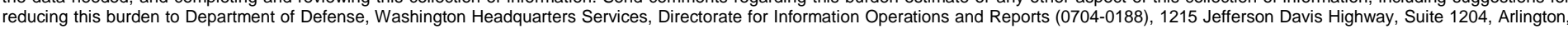

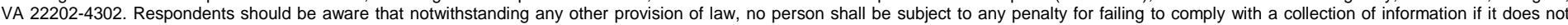
display a currently valid OMB control number. PLEASE DO NOT RETURN YOUR FORM TO THE ABOVE ADDRESS.
1. REPORT DATE (DD-MM-YYYY)
2. REPORT TYPE
3. DATES COVERED (From - To)

15 April 2012 Final

4. TITLE AND SUBTITLE

Prioritizing Historical Archaeological Sites at Fort Leonard Wood, Pulaski County,

Missouri

5a. CONTRACT NUMBER

5b. GRANT NUMBER

5c. PROGRAM ELEMENT NUMBER

6. AUTHOR(S)

Carl G. Carlson-Drexler, Ellen R. Hartman, Carey L. Baxter, and Susan I. Enscore

5d. PROJECT NUMBER

5e. TASK NUMBER

MIPR 8MDATP3072

5f. WORK UNIT NUMBER

7. PERFORMING ORGANIZATION NAME(S) AND ADDRESS(ES)

U.S. Army Engineer Research and Development Center

8. PERFORMING ORGANIZATION REPORT NUMBER

Construction Engineering Research Laboratory

ERDC-CERL TR-12-6

P.O. Box 9005

Champaign, IL 61826-9005

9. SPONSORING I MONITORING AGENCY NAME(S) AND ADDRESS(ES)

Fort Leonard Wood Directorate of Public Works

Environmental Division

Fort Leonard Wood, Missouri 65473

10. SPONSOR/MONITOR'S ACRONYM(S)

FLW DPW

11. SPONSOR/MONITOR'S REPORT

NUMBER(S)

\section{DISTRIBUTION I AVAILABILITY STATEMENT}

Approved for public release; distribution is unlimited.

\section{SUPPLEMENTARY NOTES}

\section{ABSTRACT}

The Army is tasked with managing the cultural resources on its lands. For installations such as Fort Leonard Wood that contain large numbers of historic farmsteads, meeting these requirements through traditional approaches entails large investments of time, personnel, and capital. Fort Leonard Wood and the Construction Engineering Research Laboratory have developed a model for efficiently identifying the best examples of historic sites, and also those sites that are least likely to be deemed eligible for listing on the National Register of Historic Places.

This report details the application of the data collection and analysis process developed by Enscore et al. (2005) to eight historic sites on Fort Leonard Wood Military Reservation. The results of the fieldwork show that this approach helps to quickly identify basic information about the site and provide a basis for identifying sites that have little potential for listing on the National Register. Recommendations also are offered concerning the development of the model and its application at other installations.

\section{SUBJECT TERMS}

Fort Leonard Wood, Historic Archaeology, Cultural Landscape, NRHP Eligibility, Farmsteads

16. SECURITY CLASSIFICATION OF:

\section{a. REPORT}

Unclassified b. ABSTRACT

Unclassified

\section{LIMITATION} OF ABSTRACT

\section{c. THIS PAGE}

Unclassified

\section{NUMBER} OF PAGES 19a. NAME OF RESPONSIBLE PERSON

19b. TELEPHONE NUMBER (include area code) 